\title{
Preparação e caracterização de micropartículas de colágeno ou fibroína como suporte para células-tronco
}

Dissertação de mestrado apresentada ao Programa de Pós-Graduação Interunidades em Bioengenharia Escola de Engenharia de São Carlos / Faculdade de Medicina de Ribeirão Preto / Instituto de Química de São Carlos da Universidade de São Paulo como parte dos requisitos para a obtenção do título de mestre em Ciências.

Área de Concentração: Bioengenharia

Orientador: Prof. Dr. Sérgio Akinobu Yoshioka

São Carlos

2012 
AUTORIZO A REPRODUÇÃO E DIVULGAÇÃO TOTAL OU PARCIAL DESTE TRABALHO, POR QUALQUER MEIO CONVENCIONAL OU ELETRÔNICO, PARA FINS DE ESTUDO E PESQUISA, DESDE QUE CITADA A FONTE.

Ficha catalográfica preparada pela Seção de Atendimento ao Usuário do Serviço de Biblioteca - EESC/USP

Montanha, Vanessa Camila

M764c Caracterização de micropartículas de colágeno ou

fibroína como suporte para células-tronco / Vanessa Camila Montanha ; orientador Sérgio Akinobu Yoshioka. São Carlos, 2012.

Dissertação (Mestrado) - Programa de Pós-Graduação em Interunidades Bioengenharia e Área de Concentração em Bioengenharia - Escola de Engenharia de São Carlos da Universidade de São Paulo, 2012 .

1. Micropartículas. 2. Células-tronco mesenquimais. 3. Fibroína. 4. Colágeno. 5. Glutaraldeído. I. Título. 


\section{VANESSA CAMILA MONTANHA}

Título: "Preparação e caracterização de micropartículas de colágeno ou fibroína como suporte para células - tronco".

DISSERTAÇÃO APRESENTADA AO PROGRAMA DE PÓS-GRADUAÇÃO INTERUNIDADES BIOENGENHARIA EESC/FMRP/IQSC DA UNIVERSIDADE DE SÃO PAULO PARA OBTENÇÃO DO TITTULO DE MESTRE EM CIÊNCIAS NA ÁREA DE BIOENGENHARIA.

Aprovado (a) em: 22,1012012

PROF. DR. SÉRGIO AKINOBU YOSHIOKA (ORIENTADOR)

Resultado: Aprovadd

PROF. DR. CLAUDIO ALBERTO TORRES SUAZO

Resultado: A provada PROFa. DR ${ }^{a}$. ANA MARIA MINARELLI GASPAR Resultado: APROVADA
Instituto de Química de São Carlos - USP

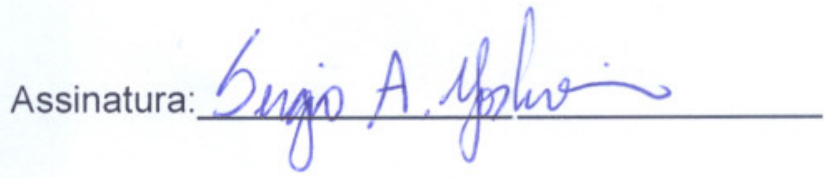

Universidade Federal de São Carlos - UFSCar

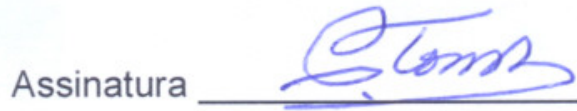

Universidade Estadual Paulista "Júlio de Mesquita Filho" - UNESP

Assinatura:

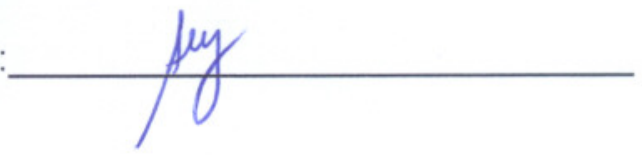




\section{DEDICATÓRIA}

Dedico este trabalho como fruto da realização dos sonhos de meus pais, Maria José e Severino Montanha, e meu querido irmão, Wagner Montanha.

Aos meus avós, Santina e Abrahão Bortolozzo (in memoriam), que na simplicidade me ensinaram que sem esforços e honestidade não se vai longe.

E ao meu sobrinho, Diego Montanha.

"Se fizer igual a todo mundo, obterá os mesmos resultados."

Roberto Shinyashiki 


\section{AGRADECIMENTO}

A Deus, por permitir chegar onde estou.

Aos meus pais, Maria Montanha e Severino Montanha, pelos exemplos e ensinamentos morais que me garantiram uma conduta idônea.

Ao professor Sergio A. Yoshioka, cuja orientação foi fundamental para meu crescimento profissional e intelectual.

A Virgínia C. A. Martins, por todo o auxílio imprescindível e não menos abnegado que dispensou a mim, contribuindo de forma fundamental para a conclusão de meu trabalho.

A Márcio de Paula, por sua contribuição com as microscopias eletrônicas de varredura que engrandecem este trabalho.

Ao professor Sérgio Luis Felisbino e minha amiga desde a graduação Carolina Sarobo, que me acolheram em seus laboratórios na Unesp - Botucatu e permitiram utilizar de seus recursos.

Ao professor Claudio Alberto Torres Suzano, por ter cedido seu laboratório (LATECC) na UFSCar e minha amiga, Thaila Wodewotzky, que apesar de seu tempo escasso foi capaz de realizar, de forma impecável, os testes in vitro deste trabalho e me ajudar sempre que precisei.

$\mathrm{E}$ a todos os amigos que estiveram torcendo pelo meu sucesso nessa caminhada: meu irmão Montanha, Sylvia Correa, Cicilia Carvalho, Andreza Tamanaha, Fernanda Del Campos, Marcelo Kravicz, Lucas Freitas de Freitas, e os amigos que fiz durante esses anos de mestrado. Meu muito obrigada! 


\title{
RESUMO
}

\author{
MONTANHA, V.C. Preparação e caracterização de micropartículas de colágeno ou \\ fibroína como suporte para células-tronco. 2012. 87 f. Dissertação (Mestrado)-Programa \\ de Pós Graduação Interunidades Bioengenharia-EESC/FMRP/IQSC-USP, Universidade de \\ São Paulo, São Carlos, 2012.
}

Diversos biomateriais podem ser aplicados na engenharia de tecidos, mas poucos são utilizados em contato direto com células-tronco na forma de suportes de micropartículas, devido à falta de adesão, espalhamento e toxicidade do material, de forma que os tornam inviáveis junto ao cultivo celular. Um biomaterial promissor para bioengenharia é a fibroína, proteína fibrosa presente no casulo do bicho da seda (Bombyx mori), devido à sua resistência mecânica, biocompatibilidade e mínima reação inflamatória, porém, suas caracteristicas são pouco conhecidas na literatura. O mesmo não ocorre com o colágeno que já é bastante estudado por pesquisadores e, assim como a fibroína, apresenta propriedades naturais que incluem baixa resposta imunológica, baixa toxicidade e habilidade de promover o crescimento celular, porém o uso do colágeno em sua maior parte é em forma de filmes, esponjas e membranas. Como existem poucos métodos relacionados para preparação e caracterização de micropartículas em formatos esféricos e porosos, este trabalho teve por objetivo desenvolver e caracterizar micropartículas à base de colágeno ou fibroína, tratadas ou não com glutaraldeído (GA), para ser utilizado como suporte para células-tronco mesenquimais e avaliar a citotoxicidade destes materiais em cultura celular.Nos resultados de Calorimetria Exploratória Diferencial para ambos os materiais, colágeno e fibroína quando submetidas a tratamento com GA, a temperatura de desnaturação e degradação aumenta, respectivamente. Na microscopia ótica, eletrônica de varredura e birrefringência, observa-se o aparecimento de rugosidade e poros e/ou bolhas de ar no interior das micropartículas em maior quantidade quando tratadas com GA, o que pode ser um fator positivo para aderência celular no suporte. A porcentagem de água absorvida é maior no colágeno devido às estruturas hidrofóbicas em maior quantidade na fibroína, porém, quando tratadas com GA, a absorção é estabilizada em um curto tempo em ambos os materiais. Os picos nos espectros de FTIR mostram as bandas amidas I, II e III dos materiais e as alterações sofridas quando em contato com GA e os testes de citotoxicidade que ambos materiais tratados ou não, são atóxicos, mas o desenvolvimento celular nas micropartículas de fibroína é mais lento e diminui quando tratados com GA, por possuir mais estruturas ordenadas na forma de $\beta$-folha quando se necessita de um crescimento mais controlado das células nas micropartículas.

Palavras Chaves: Micropartículas, Células-tronco mesenquimais, Fibroína, Colágeno, Glutaraldeído. 


\begin{abstract}
MONTANHA, V.C. Preparation and characterization of collagen or fibroin microparticles as support for stem cells 2012. 87 f. Dissertação (mestrado) - Programa de Pós Graduação Interunidades Bioengenharia-EESC/FMRP/IQSC-USP, Universidade de São Paulo, São Carlos, 2012.
\end{abstract}

There are several biomaterials can that be used in tissue engineering, but few are used in direct contact with stem cells like scaffold in the microparticle form, because of the lack of adhesion, spreading and toxicity of the biomaterial, in order to make them nonviable in the cell culture. A promising biomaterial for bioengineering is fibroin, a fibrous protein present in the fibers of silkworm (Bombyxmori) cocoon, because of its mechanical strength, biocompatibility and minimal inflammatory reaction; however, little is still described in the literature. Not so with the collagen that is already well studied by researchers and as the fibroin, has natural properties that include low immune response, low toxicity and ability to promote cell growth, but the use of collagen is mostly in form of films, sponges and membranes. As there are few methods reported for preparation and characterization of microparticles in spherical shapes and porous, this study aimed to develop and characterize microparticles based on collagen or fibroin, treated or not with glutaraldehyde (GA), to be used as a support for cells mesenchymal stem cells and evaluating the cytotoxicity of these materials in cell culture.In the results of Differential Scanning Calorimetry (DSC) curves for both materials, collagen and fibroin when subjected to treatment with GA, the denaturation and degradation temperatures increases, respectively. In Optical Microscopy, MSCanning electronic Microscopy and Birefringence results, it is observed the onset of surface roughness and porosity and or air pockets within the microparticles in greater quantity when treated with GA, which may be a positive factor for cell attachment on the support. The percentage of water absorbed is greater in the collagen structures due to more hydrophobic structure than silk fibroin, but when in treated with GA, absorption is stabilized in a shorter time in both materials. The peaks in FTIR spectra show bands amide I, II and III of the materials and the changes suffered when in contact with GA and cytotoxicity tests are non-toxic to both biomaterials treated or not, however, in the growth of cells, the fibroin microparticles is slower and decreases when treated with GA, due to its more ordered structure in the form of $\beta$-sheet and more spherical than collagen due to its more ordered $\beta$-sheet structures, which may be very interesting when it needs a more controlled growth of cells on microspheres.

Key Words: Microparticles, Mesenchymal Stem Cells, Fibroin, Collagen, Glutaraldehyde. 


\section{LISTA DE ILUSTRAÇÕES}

Figura 1. Esquema de formação da tripla hélice da molécula de colágeno................... 23

Figura 2. Estruturas folha- $\beta$ da fibroína e dos principais aminoácidos ........................ 24

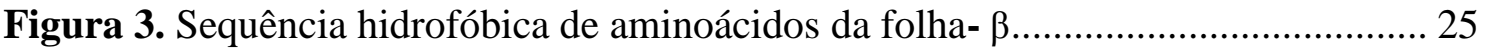

Figura 4. Formação de polímeros $\alpha, \beta$-insaturados a patir do Glutaraldeído. ............. 26

Figura 5. Diferenciação celular das Células-tronco Mesenquimais .............................. 27

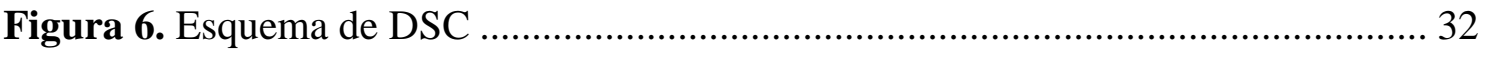

Figura 7. Fluxograma do delineamento experimental............................................ 35

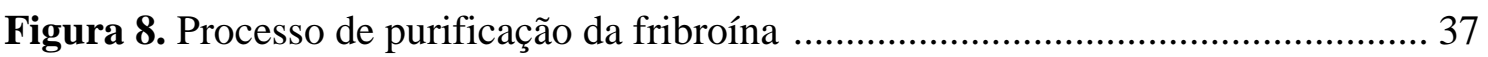

Figura 9. Processo de solubilização e diálise da fribroína........................................... 38

Figura 10. Borrifador de vidro para formação de micropartículas de fibroína. ............. 39

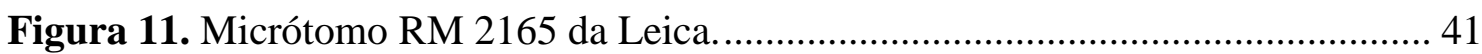

Figura 12. Representação da reação enzimática do MTT. ............................................ 45

Figura 13. Curva DSC das micropartículas de colágeno............................................ 48

Figura 14. Curva DSC das micropartículas de fibroína. ............................................ 49

Figura 15. MEV das micropartículas de colágeno não reticulado................................50

Figura 16. MEV das micropartículas de colágeno reticulado.. .................................... 51

Figura 17. MEV das micropartículas de fibroína não reticulada................................. 51

Figura 18. MEV das micropartículas de fibroína reticulada. ..................................... 52

Figura 19. MEV do interior das micropartículas reticulada ...................................52

Figura 20. MEV das micropartículas reticuladas ...................................................... 53

Figura 21. MO superficial do colágeno não reticulado .............................................. 53

Figura 22. MO superficial do colágeno reticulado................................................. 54

Figura 23. MO do corte das micropartículas de colágeno não reticulado ..................... 54

Figura 24. MO do corte das micropartículas de colágeno reticulado ........................... 55

Figura 25. MO superficial da fibroína não reticulada. ................................................ 55 
Figura 26. MO superficial da fibroína reticulada. 56

Figura 27. MO do corte das micropartículas da fibroína não reticulada ..................... 56

Figura 28. MO do corte das micropartículas da fibroína reticulada ............................ 57

Figura 29. Birrefringência do colágeno não reticulado............................................... 58

Figura 30. Birrefringência do colágeno reticulado................................................ 58

Figura 31. Birrefringência de fibroína não reticulada ..............................................59

Figura 32. Birrefringência de fibroína reticulada ...................................................... 59

Figura 33. Espectroscopia de Infravermelho do Colágeno .....................................6 60

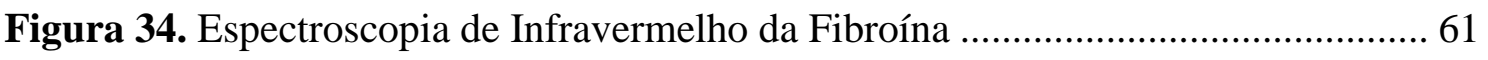

Figura 35. Porcentagem de Absorção de Água pelas micropartículas de colágeno...... 62

Figura 36. Porcentagem de Absorção de Água pelas micropartículas de fibroína......... 63

Figura 37. Microplaca com meio de cultura celular e amostras .................................. 65

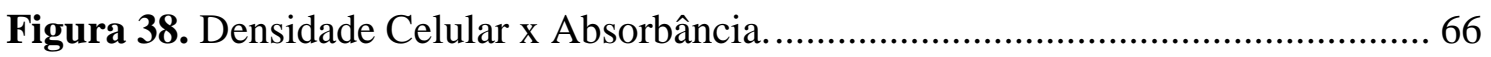

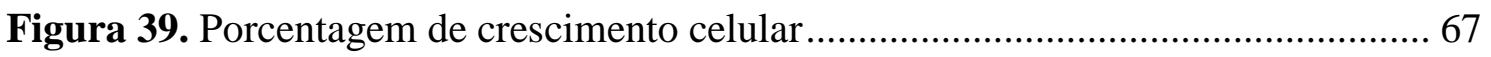

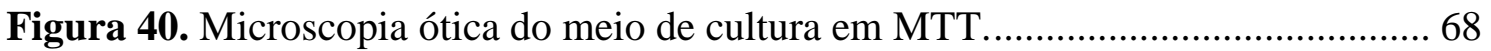

Figura 41. Microscopia ótica do meio de cultura em MTT com microcarregadores Cultispher $10 \mu \mathrm{m}$

Figura 42. Microscopia ótica do meio de cultura em MTT com microcarregadores Cultispher $50 \mu \mathrm{m}$

Figura 43. Microscopia ótica do meio de cultura em MTT com micropartículas de não cólageno reticulado $10 \mu \mathrm{m}$

Figura 44. Microscopia ótica do meio de cultura em MTT com micropartículas de não cólageno reticulado $50 \mu \mathrm{m}$ 70

Figura 45. Microscopia ótica do meio de cultura em MTT com micropartículas de cólageno reticulado $10 \mu \mathrm{m}$

Figura 46. Microscopia ótica do meio de cultura em MTT com micropartículas de cólageno reticulado $50 \mu \mathrm{m}$

Figura 47. Microscopia ótica do meio de cultura em MTT com micropartículas de fibroína não reticulada $10 \mu \mathrm{m}$. 
Figura 48. Microscopia ótica do meio de cultura em MTT com micropartículas de fibroína não reticulada $50 \mu \mathrm{m}$.

Figura 49. Microscopia ótica do meio de cultura em MTT com micropartículas de fibroína reticulada $10 \mu \mathrm{m}$

Figura 50. Microscopia ótica do meio de cultura em MTT com micropartículas de fibroína reticulada $50 \mu \mathrm{m}$ 


\section{TABELA}

Tabela 1. Teste de citotoxicidade por MTT após $72 \mathrm{~h}$ de cultivo 66 


\section{LISTA DE ABREVIATURAS E SIGLAS}

\begin{tabular}{|c|c|}
\hline Ala & Alanina \\
\hline An & Analisador \\
\hline Asp & Ácido Aspártico \\
\hline ASTM & American Society for Testing and Materials \\
\hline CAQ & Central de Análises Químicas \\
\hline CTM & Células-tronco Mesenquimais \\
\hline DSC & Calorimetria Exploratória Diferencial \\
\hline DRX & Difratometria de Raios $X$ \\
\hline FTIR & Espectroscopia no Infravermelho com Transformada de Fourier \\
\hline GA & Glutaraldeído \\
\hline Gly & Glicina \\
\hline Hyl & Hidroxilisina \\
\hline Hyp & Hidroxiprolina \\
\hline IQSC & Instituto de Química de São Carlos \\
\hline IV & Infravermelho \\
\hline Lys & Lisina \\
\hline MEC & Matriz Extracelular \\
\hline MEV & Microscopia Eletrônica de Varredura \\
\hline MO & Microscopia Ótica \\
\hline MTT & Brometo de 3-[4,5-dimetiltiazol-2-il]-2,5-difeniltetrazólio \\
\hline Pol & Polarizador \\
\hline $\mathrm{Se}$ & Serina \\
\hline
\end{tabular}


Fibroína de Seda

SFB

Soro Fetal Bovino

USP

Universidade de São Paulo 


\section{SUMÁRIO}

1.INTRODUÇÃO

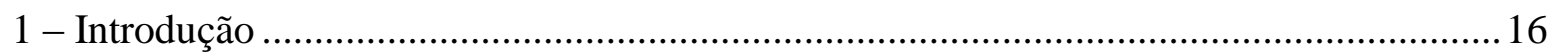

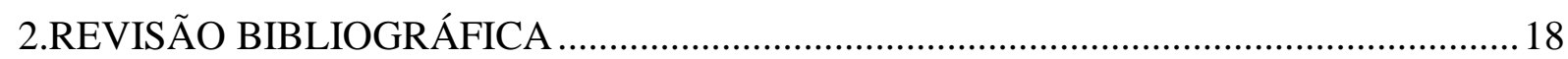

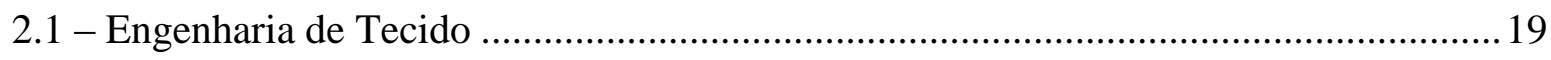

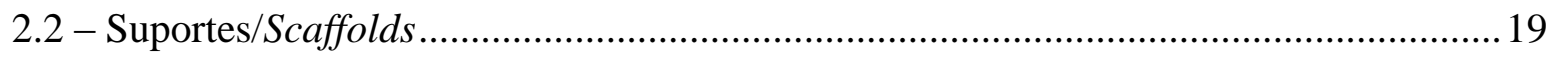

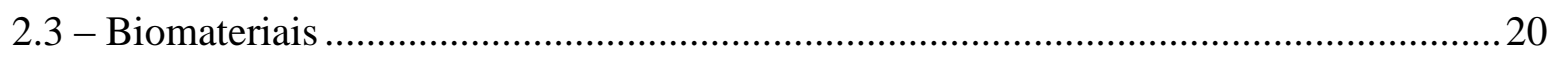

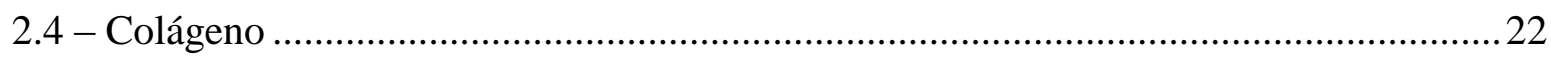

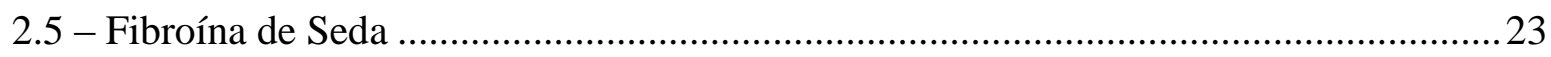

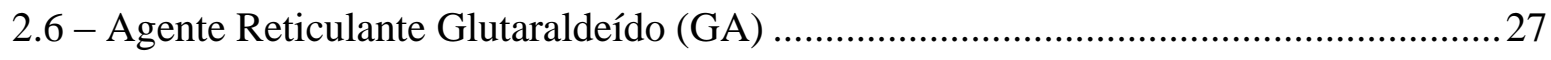

2.7 -Células-tronco Mesenquimais Suportadas sobre Biomateriais ......................................28

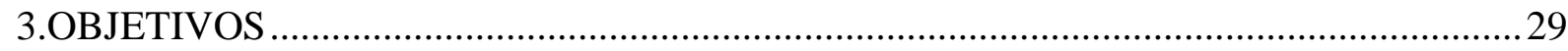

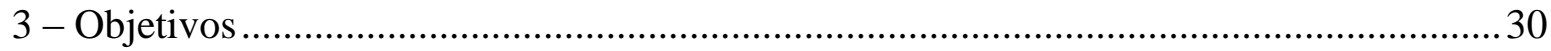

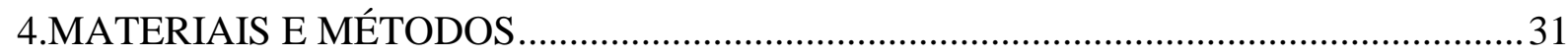

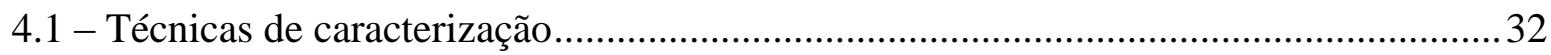

4.1.1 - Calorimetria Exploratória Diferencial (DSC) ………............................................ 32

4.1.2 - Microscopia Eletrônica de Varredura (MEV) ..........................................................33

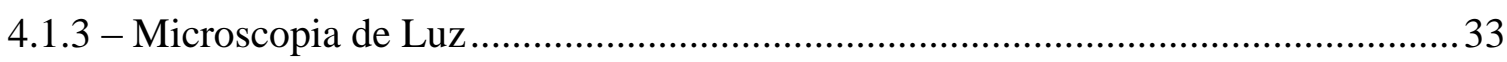

4.1.4 - Microscopia Ótica de Birrefringência ..................................................................... 34

4.1.5 - Espectroscopia no Infravermelho (FTIR) ……………………………………..... 34

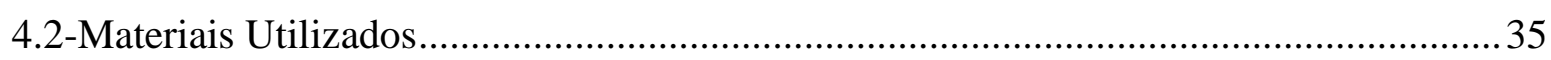

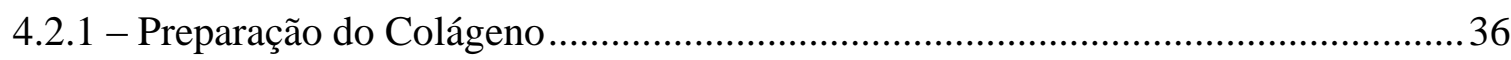

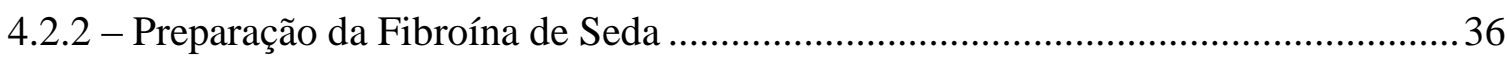

4.2.2.1 - Remoção da Sericina dos Casulos ..................................................................... 36

4.2.2.2 - Preparação da Solução de Fibroína …………………………………………..... 37

4.2.2.3 - Preparação das Micropartículas de Fibroína ........................................................38 
4.4 - Caracterização das Micropartículas de Colágeno e Fibroína ..................................... 39

4.4.1 - Análise Térmica por Calorimetria Exploratória Diferencial (DSC).................. 39

4.4.2 - Microscopia Eletrônica de Varredura (MEV) .................................................... 40

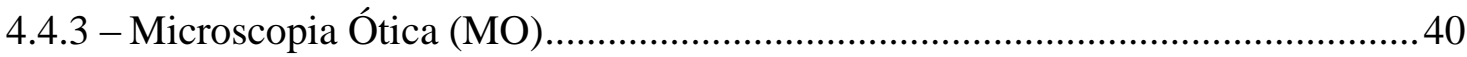

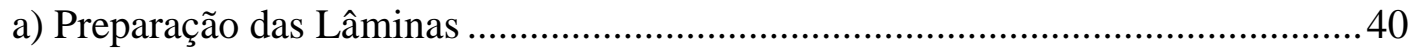

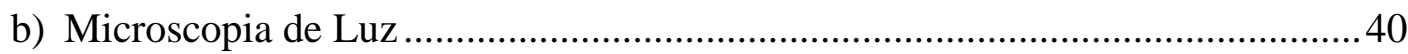

4.4.4 - Microscopia Ótica de Birrefringência .......................................................... 41

4.4.5 - Espectroscopia no Infravermelho (FTIR) ............................................... 42

4.4.6 - Percentual de Absorção de Água das Micropartículas e Porosidade. ................ 42

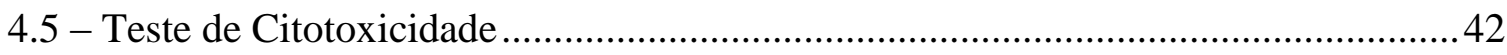

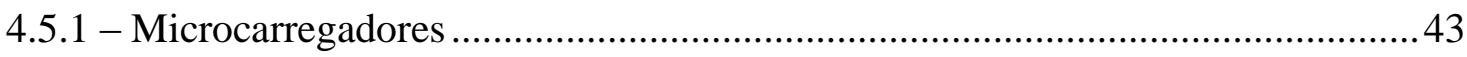

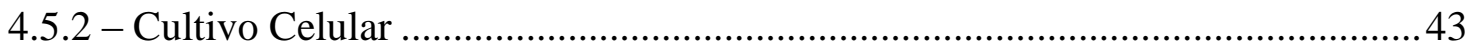

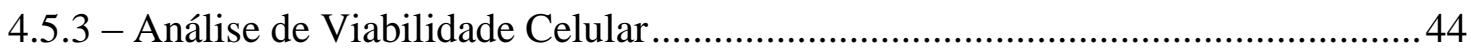

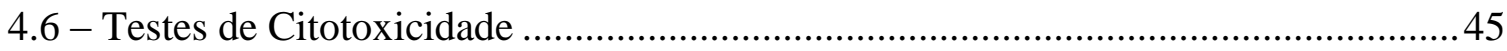

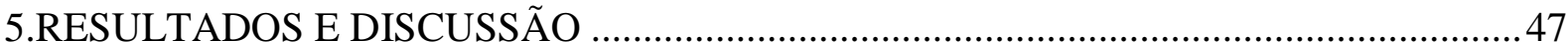

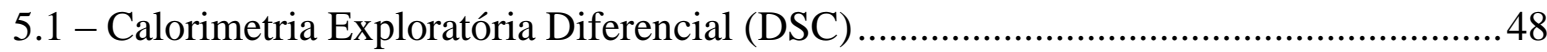

5.2 - Microscopia Eletrônica de Varredura (MEV)..........................................................50

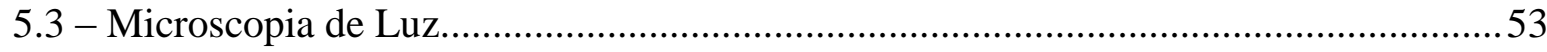

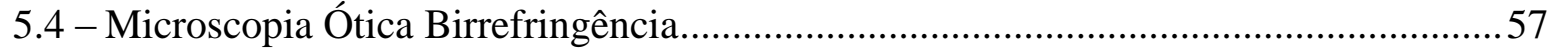

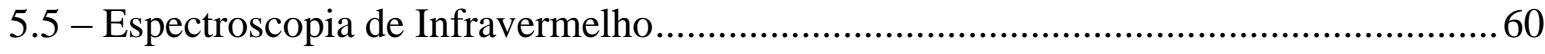

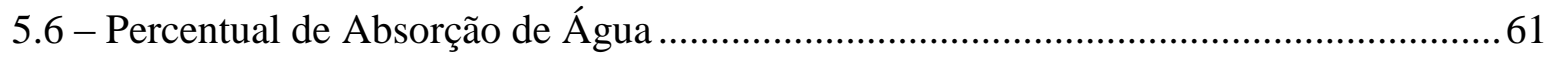

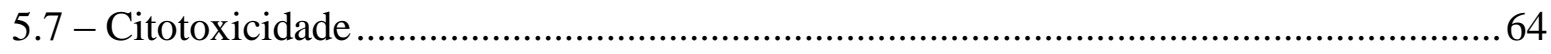

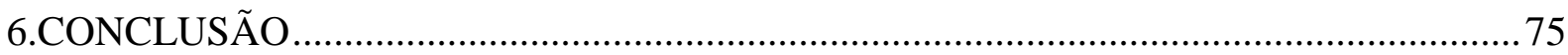

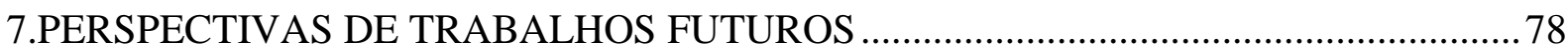

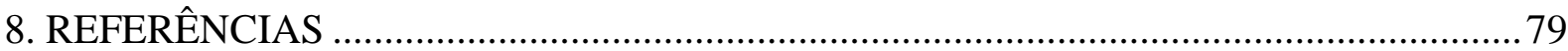


1. INTRODUÇÃO 


\section{1 - Introdução}

A engenharia de tecidos é fundamental ao exercício da medicina regenerativa e, com um mercado potencial de produtos desenvolvidos através dela, estimado em 100 bilhões de dólares ao ano (SOARES, 2005). Um dos propósitos da Engenharia de Tecidos é a regeneração de tecidos como peles, ossos, cartilagens e órgãos através da utilização de células do paciente ou não, cultivadas sobre suportes naturais ou sintéticos, que são conhecidos como scaffolds (suportes, matrizes tridimensionais, arcabouços e estruturas), para então serem reinseridos no paciente (GRIFFITH, 2002; WANG, J. et al., 2010).

Há uma enorme variedade de biomateriais formados por polímeros naturais, polímeros sintéticos e derivados de matrizes acelulares (GOMES, 2008), porém, para serem considerados biomateriais, estes devem ser isentos de produzir resposta biológica adversa local ou sistêmica, não podendo ser tóxico, carcinogênico, antigênico e mutagênico (SILVA, 2007).

A utilização de materiais sintéticos para substituição ou aumento de tecidos biológicos, sempre foi uma grande preocupação na área médica, o que justifica a investigação de novos materiais na engenharia de tecidos. A seleção do biomaterial a ser utilizado deve levar em consideração as propriedades físicas, químicas e mecânicas do material (CUNNIFF, 1995).

A necessidade de scaffolds à base de colágeno para adesão e manutenção das célulastronco embrionárias ou adultas é de grande importância, visto que no mercado são poucos os produtos disponíveis, como, por exemplo, o Verax ${ }^{\circledR}$, que se encontra na forma de microesponjas e podem ser utilizadas como carreador e imobilizador destas células até o local de sua necessidade (DEAN et al., 2003).

O colágeno é uma das proteínas mais abundante no corpo humano, pois é o principal componente da matriz extracelular de todos os tecidos conectivos, que inclui pele, tendões, vasos e ligamentos, e tem sido largamente utilizado como biomaterial para aplicações biomédicas, na forma injetável para aumento de tecidos moles e esponjas hemostáticas, para controle de sangramento em cirurgia ou após trauma grave, membranas cicatrizantes e enxertos vasculares (SHU-TUNG, L, 2000). É usado também como carreador ou transportador biodegradável para liberação controlada de fármacos, quimioterápicos e antibióticos.

Além do colágeno, outra proteína a ser mais estudada é a fibroína de seda (SF), polímero semi-cristalino, natural, produzida por Bombyx mori, conhecido popularmente como 
bicho-da-seda. Reconhecida como um material biocompatível e biodegradável, alguns estudos exploram a sua utilização como substrato para imobilização de enzimas, material compatível com o osso, material anti-trombogênico, transporte de drogas ou substrato para cultura de células (TAMADA, 2005; LIN et al.,2005 ; LI et al., 2005).

A proteína é encontrada em dois tipos cristalinos (seda I e seda II), bem como a forma espiral randômica, dependendo das condições de preparação da amostra. A seda I mostra que os deslocamentos estruturais estão associados à $\alpha$-hélice ou folha- $\beta$. A seda II é estabelecida como forma de folha $\beta$-antiparalela e é de cerca de $55 \%$ da conformação total. A distinção destas duas regiões pode ser observada por Espectroscopia Infravermelha (FTIR) e Difratometria de Raios X (DRX) (RUSA et al., 2005; TRABBIC et al., 1998).

A fibroína é um biopolímero de sequência tripeptídica: alanina (Ala), glicina (Gly) e serina (Ser), também pode apresentar ácido aspártico (Asp) em sua composição que ajuda a promover adesão celular, especialmente de células: osteoblásticas, fibroblásticas e célulastronco (SCHAFFNER, DARD 2003; REN et al., 2007).

Até o momento, poucos estudos analisam a morfologia e as características físicoquímicas da fibroína, diferente do que ocorre com o colágeno, por isso, esses fatos levantam o interesse e a necessidade de desenvolver pesquisas nessa área, com intuito de avaliar e comparar a viabilidade destes biomateriais. 
2.REVISÃO BIBLIOGRÁFICA 


\section{1 - Engenharia de Tecido}

Em meados de 1987, surgiu o termo Engenharia de Tecidos, para definir um campo de estudos multidisciplinar que compreende conhecimentos de engenharia de materiais, ciências biológicas, química e física (Five Year Plan-MATES, 2006).

A engenharia de tecidos é uma área em ascensão que objetiva o desenvolvimento de estratégias e de materiais biológicos capazes de repor tecidos que foram danificados ou perdidos (NOR, J.E.2007). Associada à medicina regenerativa, são aplicadas para a construção e o crescimento de tecidos vivos utilizando de forma isolada ou em combinação com: biomateriais, células e fatores de crescimento (GRIFFITH, NAUGHTON, 2002; SITTINGER et al., 1996; LANGER, VACANTI, 1993).

A regeneração de orgãos e tecidos pode ser feita com tecidos vindos do próprio paciente, dissociando as células e cultivando-as sobre suportes biológicos ou sintéticos conhecidos como scaffolds (suportes, matrizes tridimensionais, arcabouços, estruturas) para então serem reinseridos no paciente (GRIFFITH, NAUGHTON, 2002; PITTINGER et al., 1996; LANGER, VACANTI, 1993). Para a produção de um novo tecido é necessário que os scaffolds apresentem estruturas tridimensionais e compostos que possam estimular o crescimento e desenvolvimento celular (ROSA et al., 2008).

Como a engenharia de tecidos é uma área relativamente nova pesquisadores vem buscando a padronização da terminologia e da metodologia de pesquisa e aplicação dos produtos preparados. A regulamentação vem sendo feita por normas da American Society for Testing and Materials - ASTM ( F2312-03, F2027-00e1 e F2150-02e1) e por orgãos governamentais de países da Europa, Canadá, Japão e outros ( LLOYD-EVANS et al., 2004), de forma a assegurar a seus usuários a confiabilidade do produto.

\section{2 - Suportes/Scaffolds}

Scaffolds são suportes em que há o cultivo de células teciduais juntamente com fatores de crescimento, permitindo o desenvolvimento do tecido até o suporte ser substituido completamente (MA, 2004). Para cumprir essa função, o suporte deve possuir propriedades como biocompatibilidade, porosidade com tamanho e formato de poros adequados para 
permitir o crescimento de tecidos e grande área superficial, para que haja vascularização (MA, 2000).

Um suporte deve conferir sustentação mecânica, proteção (JANCAR et al., 2007) e condições para que as células, ao produzirem matriz extracelular, construam um ambiente tridimensional, com interatividade célula-matriz em que as células, quando transplantadas, se infiltrem e permaneçam ligadas, não perdendo a capacidade de proliferar e diferenciar para então produzir o tecido desejado (PUTNAM, MOONEY,1996). Os scaffolds podem ser obtidos a partir de material cerâmico (XU, 2008; ZHANG, 2008) ou polimérico (ALSBERG, 2003) ou mesmo da associação destes (KHAN et al., 2006).

Um scaffold, quando poroso, tende a fornecer melhores condições de transporte de nutrientes para as células, assim como proporcionar a migração celular e uma melhor superfície para adesão, enquanto um scaffold com menos poros oferece melhores propriedades mecânicas (HOLLISTER, 2005). O transporte de massa (permeabilidade e difusão) permite que nutrientes do meio de cultura alcancem as células inseridas nos poros, o que mantém a viabilidade celular e promove a homeostase mediante o bom funcionamento de todas as funções fisiológicas celulares.

A biocompatibilidade do material é essencial, pois, ao introduzi-lo no tecido lesado, deve ser aceito pelo tecido justaposto sem respostas imunológicas e inflamatórias danosas. A bioabsorção deve ser compatível à capacidade das células em produzir matriz, de modo que, aos poucos, as células ocupem os espaços intersticiais e substituam por completo o material do scaffold (HOLLISTER, 2005).

\section{3 - Biomateriais}

Utilizados em dispositivos médicos de forma temporária ou permanentemente implantados no corpo humano, o termo biomaterial foi definido na Conferência do Instituto Nacional de Desenvolvimento de Consenso em Saúde em 1982 como:

“Qualquer substância (outra que não droga) ou combinação de substâncias, de origem sintética ou natural, que possa ser usada por um período de tempo, completa ou parcialmente como parte de um sistema que trate, aumente ou substitua qualquer tecido, órgão ou função do corpo" (HELMUS, TWEDEN, 1995). 
Há uma enorme variedade de biomateriais que podem ser denominados, de forma geral, de polímeros naturais, sintéticos e derivados de matrizes acelulares (GOMES et al., 2008), porém, para ser considerado biomaterial, estes devem ser isentos de produzir qualquer resposta biológica adversa local ou sistêmica, atóxico, não carcinogênico, antigênico e mutagênico (SILVA, 2007).

O critério de seleção do biomaterial dependerá da aplicação a que se destina e levada em consideração às similaridades físicas, químicas e biológicas destes, em relação ao tecido a ser substituído (OGAWA, 2002). Os biomateriais devem ser compatíveis com os tecidos hospedeiros, de modo a estimularem uma resposta adequada dos mesmos, apresentando, portanto, uma propriedade importante: a biocompatibilidade (SILVA, 2007).

A biocompatibilidade é definida como "estado de mútua coexistência entre o material e o ambiente fisiológico, sem que exerça efeitos desfavoráveis sobre o outro" (BOSS et al., 1995), de modo que reflita diretamente o sucesso do implante no organismo e diminua dessa forma o risco de rejeição.

Quando o corpo humano entra em contato com um material sintético, o tecido reage aos implantes de formas diferentes dependendo da composição, das características superficiais e da carga funcional aplicada. No geral alguns termos descrevem ou classificam um biomaterial em relação a sua interação com o tecido, como: bioinerte, bioativo e biodegradável/biorreabsorvível (RODRIGUEZ, A.I.R.; BICALHO, S.M.C.M. 2009).

De acordo com a Conferência da Sociedade Européia para Biomateriais realizada na Inglaterra em 1986, o termo bioinerte não é adequado, já que todo material induz algum tipo de resposta do tecido hospedeiro, mesmo que mínima, por este motivo deve ser evitado. No entanto, o termo ainda é comumente utilizado, como sendo um material que apresenta uma resposta interfacial mínima que não resulta na ligação ou na rejeição do tecido hospedeiro (KAWACHI et al. 2000).

A bioatividade é a capacidade do material em induzir uma reação biológica específica e interagir intimamente com o tecido. A biodegradação é a diminuição gradual em termos de material mediada por atividade biológica ou bioquímica específica; e a bioreabsorsão é o processo de remoção do material mediada por atividade celular, diretamente por fagocitose ou através de ação enzimática ou mesmo por difusão iônica contínua do biomaterial quando estes são colocados em meios biológicos (RAVAGLIOLI, KRAJEWSKI, 1992; HENCH, 1991).

Entre os muitos biomateriais utilizados, os polímeros apresentam grande potencial de uso, por apresentar características mecânicas semelhantes às dos materiais biológicos e ser de fácil manuseio (GRIFFITH, 2000). Os polímeros biorreabsorvíveis como, por exemplo, o 
colágeno, tem uma grande importância na área médica, pois são utilizados em um amplo número de aplicações no corpo humano como: suturas cirúrgicas (KULKARNI, 2004), sistemas para liberação controlada de drogas (LIU, 2004), scaffolds (VALIMAA, 2004) e dispositivos ortopédicos (AMBROSE, 2004).

\section{4 - Colágeno}

O colágeno representa uma das proteínas estruturais e corresponde aproximadamente a $30 \%$ das proteínas dos vertebrados. Mais de $90 \%$ das proteínas de matriz extracelular (MEC) de tendões e ossos e mais de $50 \%$ da MEC da pele consistem de colágeno.

Encontrado em grande quantidade no tecido conjuntivo, o colágeno tem a função de manter a integridade estrutural do tecido e conferir resistência mecânica e elasticidade (TZAPHLIDOU, 2004; CHAPMAN, 1990). As diferentes propriedades destes tecidos são, em parte, devido ao resultado de diferentes organizações das fibras de colágeno. Sua principal característica é a formação de fibras insolúveis com alta força elástica. Além de seu papel estrutural nos tecidos, o colágeno possui também outras características, tais como a função de orientar os tecidos em desenvolvimento (CHAUDRY, 1997; MAYNE et al., 1987).

$\mathrm{Na}$ forma de filamento semi-flexível de $300 \mathrm{~nm}$ de comprimento e 1,5 nm de diâmetro, a estrutura fundamental do colágeno é formada por uma unidade monomérica denominada tropocolágeno, constituído de três cadeias polipeptídicas denominadas $\alpha$. Essas cadeias que formam o tropocolágeno apresentam-se na forma helicoidal, ancoradas umas nas outras por ligações de hidrogênio (UTRACKI, 1990; EASTOE, 1967).

$\mathrm{O}$ arranjo dos aminoácidos nas cadeias $\alpha$ consiste em tripletes em que o terceiro resíduo é a glicina (Fig.1). A forma mais comum, correspondente a um terço das estruturas, é o tipo -(Gly-X-Y) $)_{n^{-}}$, com X sendo prolina (Pro) e Y hidroxiprolina (Hyp) (BRODSKY, RAMSHAW, 1997). 


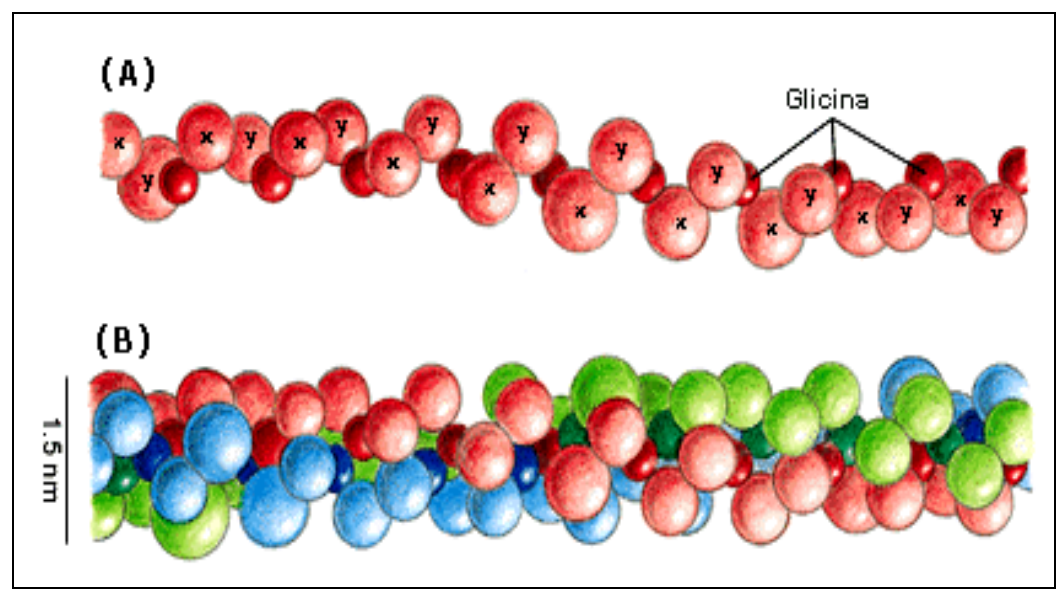

Figura 1. Esquema de formação da tripla hélice da molécula de colágeno. Fonte: Alberts, 1994.

O colágeno possui características distintas como biomaterial quando comparado com um polímero sintético, sendo a mais importante o modo de interação com os tecidos do corpo. Isso está associado com propriedades naturais que incluem baixa resposta imunológica, baixa toxicidade, a habilidade de promover o crescimento celular e a reconstrução in vitro da estrutura microfibrilar encontrada em tecidos naturais (SIONKOWSKA, 2000).

O interesse no uso do colágeno modificado quimicamente ou na forma de compósito com outros materiais têm se mostrado intensamente ampliado, principalmente devido às crescentes aplicações práticas destes novos materiais, já que os principais estudos estão voltados para a melhoria de suas propriedades físicas, físico-químicas e de processamento dos mesmos, comparadas às propriedades dos polímeros puros, visando atender aplicações específicas na área de biomateriais (BRODSKY e RAMSHAW, 1997).

\section{5 - Fibroína de Seda}

A fibroína de seda produzida por Bombyx mori, popularmente conhecido como bichoda-seda, é composta por dois tipos de proteínas: a sericina, que envolve as fibras e a fibroína, que é a fibra da seda composto de regiões altamente organizadas com cristais folha- $\beta$ e semicristalinas, responsáveis pela elasticidade da seda (ALTMAN et al., 2003) e regiões amorfas que contêm a maioria dos resíduos de aminoácidos com uma cadeia lateral volumosa e polar.

Composta quimicamente por glicina, alanina, serina (Fig. 2) e em menor quantidade, tirosina e outros aminoácidos residuais, as propriedades de tensão da fibroína da seda 
dependem principalmente da estrutura cristalina, enquanto outras propriedades, como retenção de umidade e resistência química, dependem do estado da região amorfa (MORI e TSUKADA, 2000).

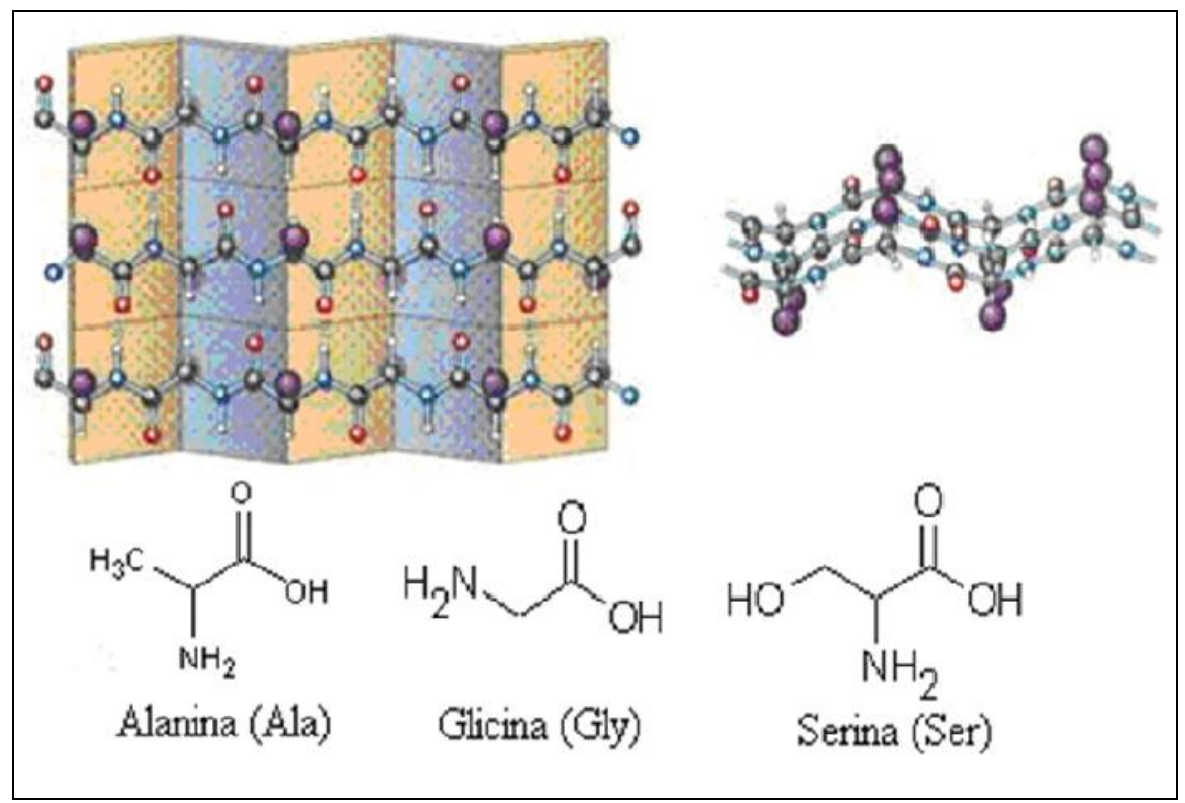

Figura 2. Estruturas folha- $\beta$ da fibroína e dos principais aminoácidos que a compõem. Fonte: Nelson e Cox, 2000.

A fibroína é constituída de duas cadeias conectadas por uma ligação dissulfídica (TANAKA et al., 1999): a cadeia com maior massa molecular ( 350 kDa) é composta por domínios repetitivos de Gly-Ala-Gly-Ala-Gly-Ser. Ao lado do grande número de resíduos hidrofóbicos, esta cadeia apresenta resíduos de hidroxila (serina e tirosina) responsável por promover afinidade com a água. Já a cadeia mais leve ( $25 \mathrm{kDa})$ não apresenta regiões repetitivas, porém contém grande quantidade de ácido aspártico e ácido glutâmico (HOSSAIN et al., 2003).

A estrutura da fibroína da seda I é uma estrutura solúvel em água que ao, ser exposta ao calor ou processo de fiação, facilmente se converte em uma estrutura da fibroína da seda II. A estrutura seda I é observada in vitro em condições aquosas e é convertida a uma estrutura folha- $\beta$ quando exposta a metanol ou cloreto de potássio (VEPARI; KAPLAN, 2007).

As estruturas de folha- $\beta$ são assimétricas, com um lado ocupado por hidrogênios de glicina e o outro ocupado por grupos metila das alaninas, que ocupam o domínio hidrofóbico. As folhas- $\beta$ estão em um arranjo nos quais grupos metila e hidrogênios das folhas- $\beta$ opostas interagem para formar um empilhamento inter-estrutural nos cristais (VEPARI; KAPLAN, 2007) (Figura 3). 
A sequência de aminoácidos da folha- $\beta$ formando os domínios cristalinos da fibroína é dominada pela sequência hidrofóbica GAGAGSGAAG [SG (AG)2]8Y (JIN; KAPLAN, 2003). A estrutura da seda II exclui água e é insolúvel em muitos solventes incluindo ácidos fracos e condições alcalinas e agentes caotrópicos.

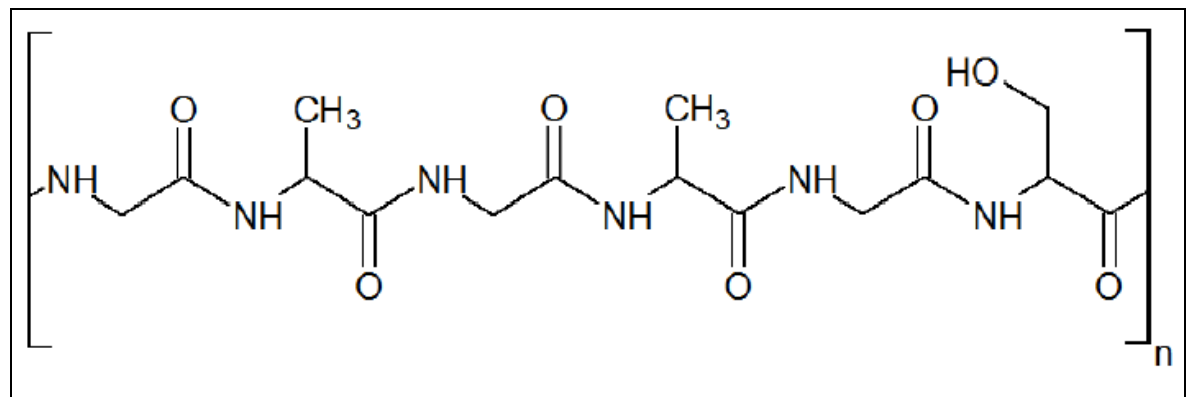

Figura 3: Sequência hidrofóbica de aminoácidos da folha- $\beta$ dos domínios cristalinos da fibroína.

A configuração estrutural confere à fibroína propriedades mecânicas que incluem alta elasticidade e flexibilidade. Recentemente, vários pesquisadores têm investigado a fibroína como um material promissor para biotecnologia e material biomédico (KITAGAWA, YABUKI, 2001; ALTMAN et al., 2003), devido à sua biocompatibilidade com diversos tipos de células, alta permeabilidade para o oxigênio e vapor d'água, boa biodegradabilidade e mínima reação inflamatória.

Alguns pesquisadores verificaram a interação da fibroína de seda com fibroblastos (SERVOLI et al., 2005), queratinócitos (GUPTA et al., 2007) e células endoteliais (FUCHS et al., 2006). A habilidade do material implantado de aderir e deixar crescer células endoteliais são características desejadas em materiais cardiovasculares, uma vez que o crescimento de uma camada celular na superfície do material pode melhorar suas características como, por exemplo, resistência mecânica (FEUGUIER et al., 2005).

Outras propriedades importantes, além da alta resistência mecânica e microbiana, possibilitam sua utilização como substratos para cultura celular, imobilização enzimática, lentes de contato com alta permeabilidade ao oxigênio, agentes de liberação de fármacos e proteção de feridas (SANTIN et al., 1999; UM et al., 2001, LI et al., 2002; LI et al.,2003; MEINEL et al., 2005; BADAMI et al., 2006; LIANG et al., 2007). 


\section{6 - Agente Reticulante Glutaraldeído (GA)}

Uma propriedade importante para as matrizes extracelulares é a biodegradabilidade, a qual ocorre com a formação do novo tecido, para tanto, o controle do tempo de degradação das matrizes é interessante e pode ser obtido por reações de reticulação. Essas reticulações existem naturalmente no tecido, tanto na formação de reticulações intramoleculares como intermoleculares, contudo, pode-se obter materiais mais reticulados com ajuda de alguns reagentes como o glutaraldeído.

$\mathrm{O}$ agente reticulante glutaraldeído ou 1,5 pentanodial $(\mathrm{HOC}-(\mathrm{CH} 2) 3-\mathrm{COH})$ é utilizado em imobilização e reticulação de proteínas através de seus grupos aminos residuais, com capacidade de reduzir a antigenicidade e melhorar as propriedades mecânicas através da formação de ligações cruzadas do tipo base de Schiff (BEPPU et al. 1999). Entretanto, estas reações não são sempre homogêneas em virtude da heterogeneidade do tecido e da química complexa do GA (Fig.4) cujas soluções são caracterizadas por misturas complexas em equilíbrio contendo GA livre, formas mono e diidratadas, hemiacetais cíclicos (monomérico e polimérico) e vários polímeros $\alpha, \beta$-insaturados (WOODROOF, 1978).

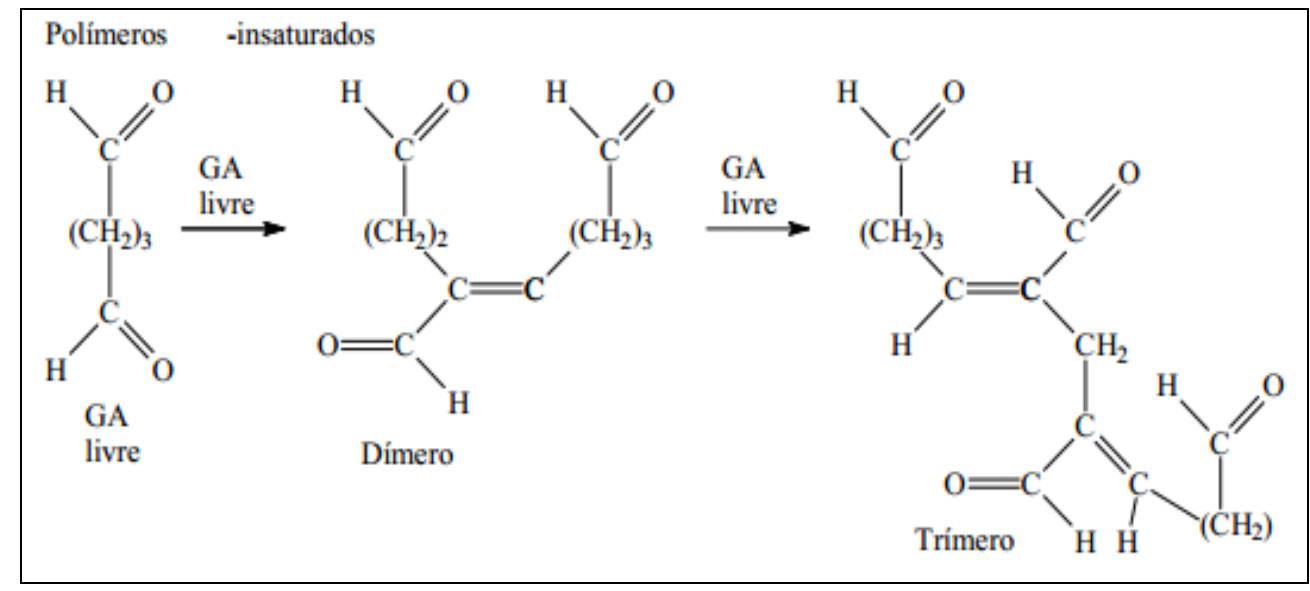

Figura 4. Formação de polímeros $\alpha, \beta$ - insaturados a partir do Glutaraldeído.

Um dos resultados da reação do GA é a impermeabilização superficial do tecido para formar ligações de reticulação poliméricas (CHEUNG, 1982; CHEUNG, 1985) do tipo poliGA. Esta impermeabilização permite manter as características originais da matriz tecidual (CHEUNG, 1985).

O método de reticulação é simples, barato e conveniente para ligantes sensíveis a $\mathrm{pH}$ alcalino. A ligação covalente entre o grupo amino e o grupo aldeído terminal do glutaraldeído 
é irreversível e resiste a extremos de pH e temperatura (BEPPU et al. 1999).

Os processos alternativos para minimizar os problemas da reticulação com GA têm sido introduzidos e pode incluir pré-tratamento com éteres glicidílicos e hexametileno diisocianatos (NAIRMARK et al. 1995), glicerol (XI et al. 1992), azidas (PETIT et al., 1994), ou mesmo procedimentos alternativos utilizando o próprio GA (SONG et al., 1990, GOISSIS, YOSHIOKA,1998), tais como a fixação dinâmica, o uso de temperaturas elevadas, ou ainda, o tratamento com concentrações baixas de GA (GOISSIS et al. 1998).

\section{7 - Células-tronco Mesenquimais Suportadas sobre Biomateriais}

As células-tronco provenientes da medula óssea têm recebido grande atenção por apresentarem uma maior facilidade de isolamento e cultivo, e pelo alto potencial de expansão in vitro (SANCHEZ et al.,2005; MORONE et al., 2008). Recentes estudos demonstraram que as células-tronco mesenquimais (CTM) têm a capacidade de se diferenciar em células com características mesenquimais (VOSKERICIAN, 2006), ectodermais (Le BLANC et al., 2003; BOSNAKOVSKI, 2006) e endodermais (WANG et al., 2005) (Figura 5). Dentre as linhagens de células de tecidos mesodermais, as CTM podem gerar ossos, cartilagens, tecidos adiposos, tendões e músculos (SILVA, 2005; ORLIC et al., 2001). Experimentos mostram também que essas células-tronco circulantes têm o potencial de diferenciação em hepatócitos maduros, células epiteliais da pele e do trato intestinal e podem melhorar a função do coração após um infarto do miocárdio (SATOH, 2004; KORBLIN, 2002; MANGI, 2003).

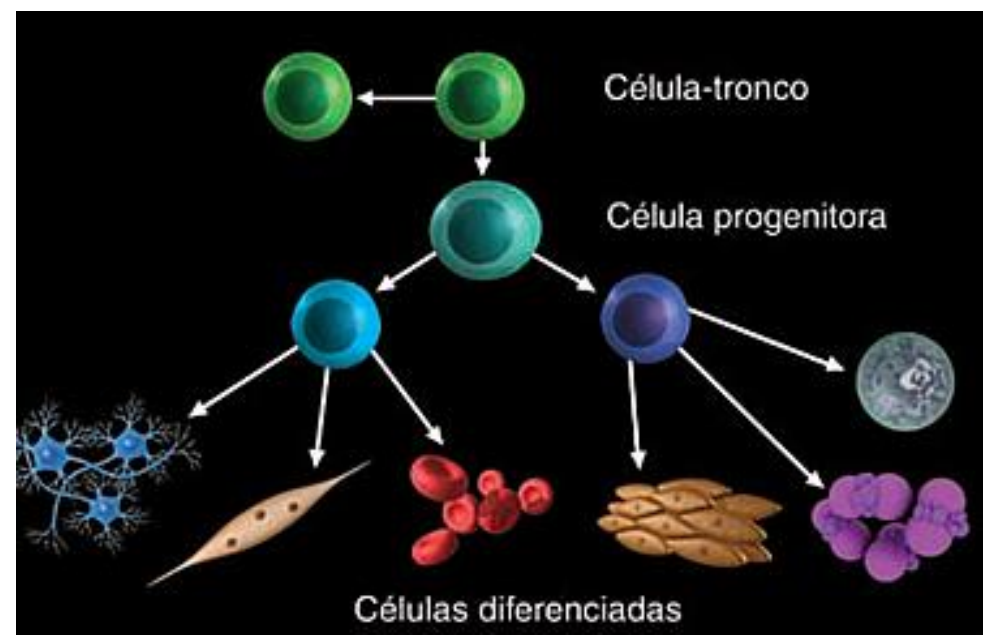

Figura 5: Diferenciação celular das Células-tronco Mesenquimais. 
As CTMs são usadas em terapias celulares: na implantação destas para localizar doenças no organismo; em transplantes sistêmicos; na combinação entre a terapia celular com células-tronco e a terapia gênica e na engenharia de tecidos (ANGELE et al., 2009).

Existem hoje, dentro da engenharia de tecidos, numerosas estratégias para a regeneração de peles lesionadas, dentre elas, o uso de membranas temporárias (como enxertos provenientes de pele de animais - suínos), membranas sintéticas, substitutos alogênicos compostos por polímeros biodegradáveis e biorreabsorvíveis, peles ou tendões de animais ou pela ação biossintética de bactérias, fatores de crescimento, transplantes autogênicos, substitutos permanentes de pele (como a cultura de derme e epiderme in vitro). Tudo isto visa aumentar a taxa de sobrevivência e melhores condições de vida dos pacientes (FREISCHLAG et al., 1994; FISCARELLI, 2004).

A aplicação de géis ou membranas de colágeno e fibroína como biomaterial em cirurgia plástica tem sido bastante aprimorado e cresceu muito nas últimas décadas, principalmente com o desenvolvimento da engenharia de tecidos, o que leva a um aumento no interesse em desenvolver materiais biodegradáveis e biocompatíveis para regeneração de tecidos (ANGELE et al., 2009). Isto se deve à sua grande abundância e fácil obtenção no reino animal e por possuir propriedades físicas, físico-químicas positivas para aplicações específicas na área de biomateriais.

A utilização biomateriais ainda é controverso devido à sua baixa eficiência; entretanto, acredita-se que a combinação destes com a terapia celular pode levar à observação de resultados promissores para o tratamento de pacientes que não obtiveram sucesso com tratamentos convencionais (GIBRAN, 1994). Assim, biomateriais feitos de polímeros como colágenos e fibroína vêm sendo desenvolvidos para atuarem como sítios atrativos para ancoragem de novas células, servindo como um suporte para o crescimento tecidual (ANGELES, 2009). 
3. OBJETIVOS 


\section{3 - Objetivos}

Preparar e caracterizar micropartículas de colágeno e de fibroína na forma esférica, tratadas ou não com agente reticulante, glutaraldeído (GA), para serem utilizadas como suportes para células-tronco mesenquimais, verificando sua viabilidade e citotoxicidade. 
4. MATERIAIS E MÉTODOS 


\section{1 - Técnicas de caracterização}

\subsection{1 - Calorimetria Exploratória Diferencial (DSC)}

Differential Scanning Calorimetry (DSC) é a técnica pela qual se mede a diferença de energia fornecida à substância e a um material de referência, termicamente inerte, em função da temperatura a uma programação controlada de temperatura que permite avaliar as variações de entalpias que ocorrem com uma dada substância durante um processo de aquecimento ou resfriamento (CANEVAROLO, 2004).

A amostra e referência são colocadas em diferentes panelas de alumínio, localizadas sobre um disco termoelétrico (sensor de resistência térmica) e aquecidas por uma única fonte de calor (Fig.6). O calor é transferido através do disco termoelétrico para a amostra e a referência, e o fluxo de calor diferencial entre os dois é controlado por termopares conectados abaixo das panelas de alumínio. Dessa forma, a diferença no fluxo de calor da amostra e da referência é diretamente proporcional à diferença de potência das junções dos dois termopares (MARKOVA, K.; FILIPPIDIS, A., 2001).

A adição de energia por unidade de tempo é registrada em função do tempo ou da temperatura e através das avaliações de temperaturas são realizadas as análises térmicas e as propriedades físicas do material, já que é possível observar que a adição de energia é proporcional à capacidade calorífica da amostra.

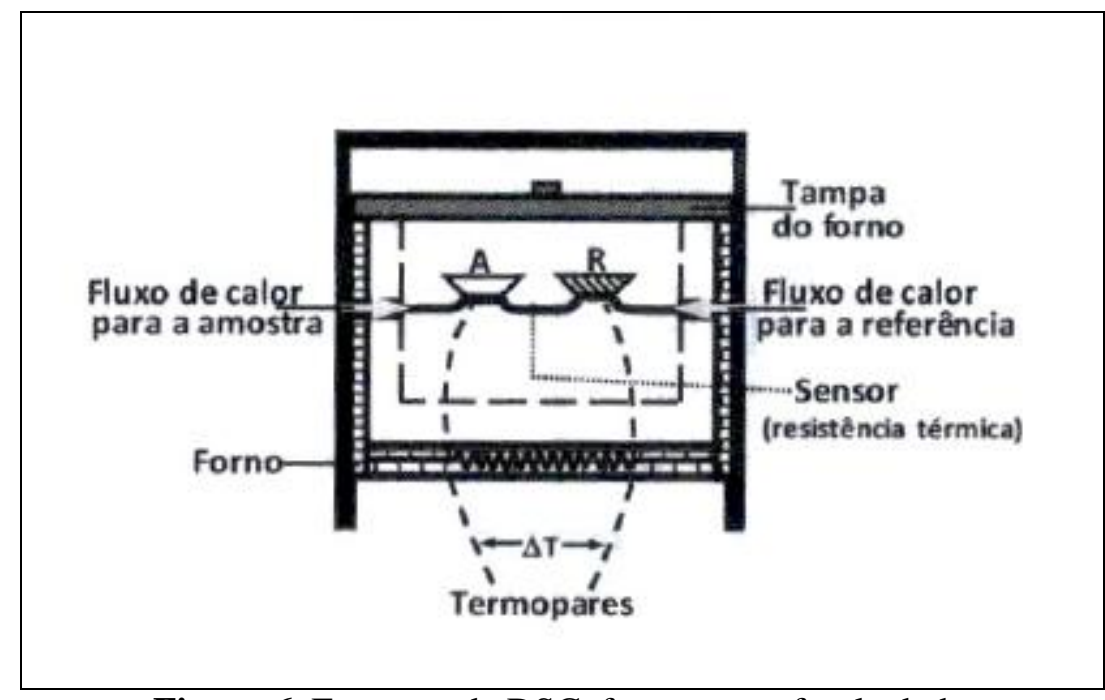

Figura 6. Esquema de DSC, fonte: www.fasul.edu.br 


\subsection{2 - Microscopia Eletrônica de Varredura (MEV)}

A imagem observada no MEV é resultado da variação de contraste que ocorre quando um feixe de elétrons varre a superfície da amostra em análise ponto a ponto em seqüência de tempos determinados. De maneira geral, as variações de contraste ponto a ponto ocorrem devido à variação do número de elétrons emitidos da amostra e que atingem ao detector, é formado por um cintilador, tubo de luz e fotomultiplicadora (VIDAL, 1995 a).

O detector é isolado eletricamente do resto do microscópio e possui na sua frente uma grade com potencial positivo. Os elétrons secundários, que possuem energia inferior a $50 \mathrm{eV}$, são atraídos por esta grade carregada positivamente, permitindo assim que o sistema colete os sinais obtidos e produza imagens tridimensionais com grandes aumentos (VIDAL,1995 a).

Para a análise micrográfica, as amostras foram aderidas em portas-amostra com a utilização de uma fita dupla-face condutora de carbono, de forma a expor as superfícies das micropartículas de colágeno e de fibroína. Antes da análise, as amostras foram liofilizadas e metalizadas com ouro para garantir a condutividade elétrica de sua superfície de observação.

\subsection{3 - Microscopia de Luz}

O microscópio ótico é feito de dois filtros polarizadores: o Polarizador (Pol) e o Analisador (An). O Pol está localizado abaixo do condensador do microscópio ótico, e possibilita se mover para ser removido ou colocado no trajeto da luz, além de uma rotação de $360^{\circ}$, já o An um polarizador que está acima de objetivas e abaixo das oculares, assim, a luz polarizada (com o vetor elétrico vibrante e um só plano) emitida, encontrará o plano de polarização do analisador perpendicular à sua direção de vibração, esse processo ocorre pela própria natureza dos polarizadores.

Através da MO é possível analisar as fibras de colágeno e fibroína devido a uma propriedade existente neste tecido, a anisotrópica ótica, que se refere a birrefringência de forma textural, bem como a ordem molecular, da direção da vibração, de momento de transição e de variação nos estados de agregação molecular (VIDAL,1987 a ). 


\subsection{4 - Microscopia Ótica de Birrefringência}

Um raio de luz polarizado, ao atravessar o material, sofre o fenômeno da dupla refração, apresentando dois raios refratados: um lento e outro rápido, cujas velocidades são inversamente proporcionais aos índices de refração. A diferença numérica entre estes dois índices de refração recebe o nome de birrefringência.

A birrefringência é uma propriedade anisotrópica ótica, podendo determinar e quantificar a ordenação macromolecular de estruturas biológicas, informando sobre a morfologia e direção das fibras de colágeno e fibroína, através da propagação desigual da luz.

O material birrefringente, ao ser analisado pela microscopia de polarização, apresenta um brilho intenso exibido pelas fibras e fibrilas, correspondentes aos índices de refração, quando são posicionadas à $45^{\circ}$ do plano de polarização de luz, esta alta intensidade de brilho é proporcional à espessura do material em análise e a diferença de fase entre as frentes de luz emergentes do material em análise (VIDAL, 1987 a).

\subsection{5 - Espectroscopia no Infravermelho (FTIR)}

Espectrometria é considerada um processo analítico-instrumental que avalia propriedades de absorção, emissão e reflexão de energia eletromagnética em cada região específica do espectro (PAVIA, 1996; SILVERSTEIN, 2000). A espectroscopia no infravermelho (IV) compreende a região do espectro eletromagnético em que os comprimentos de onda variam de 0,75 a $1000 \mu \mathrm{m}$.

A absorção de energia provoca perturbações nas frequências específicas das diferentes ligações químicas, ou seja, a frequência de cada ligação corresponde a um nível vibracional e depende da superfície de energia potencial da molécula, da geometria molecular, das massas dos átomos e eventualmente do acoplamento vibrônico. Deste modo, grupos funcionais distintos apresentam absorção com intensidade e em regiões distintas do espectro, fazendo da espectrometria de infravermelho, uma metodologia bastante útil na identificação de compostos orgânicos (MILMAN B.L.,2005; SKOOG D.A., 2002). 


\section{2 - Materiais Utilizados}

Realizaram-se diversos testes iniciais para determinar as melhores condições de desenvolvimento e caracterização das micropartículas de colágeno e fibroína, contudo, apenas as melhores condições de preparação estão descritas nessa dissertação assim como os caracterizados, os demais testes estão descritos na patente (MONTANHA, WODEWOTZKY, YOSHIOKA, 2011).

O trabalho experimental foi desenvolvido de acordo com o fluxograma mostrado na Figura 7.

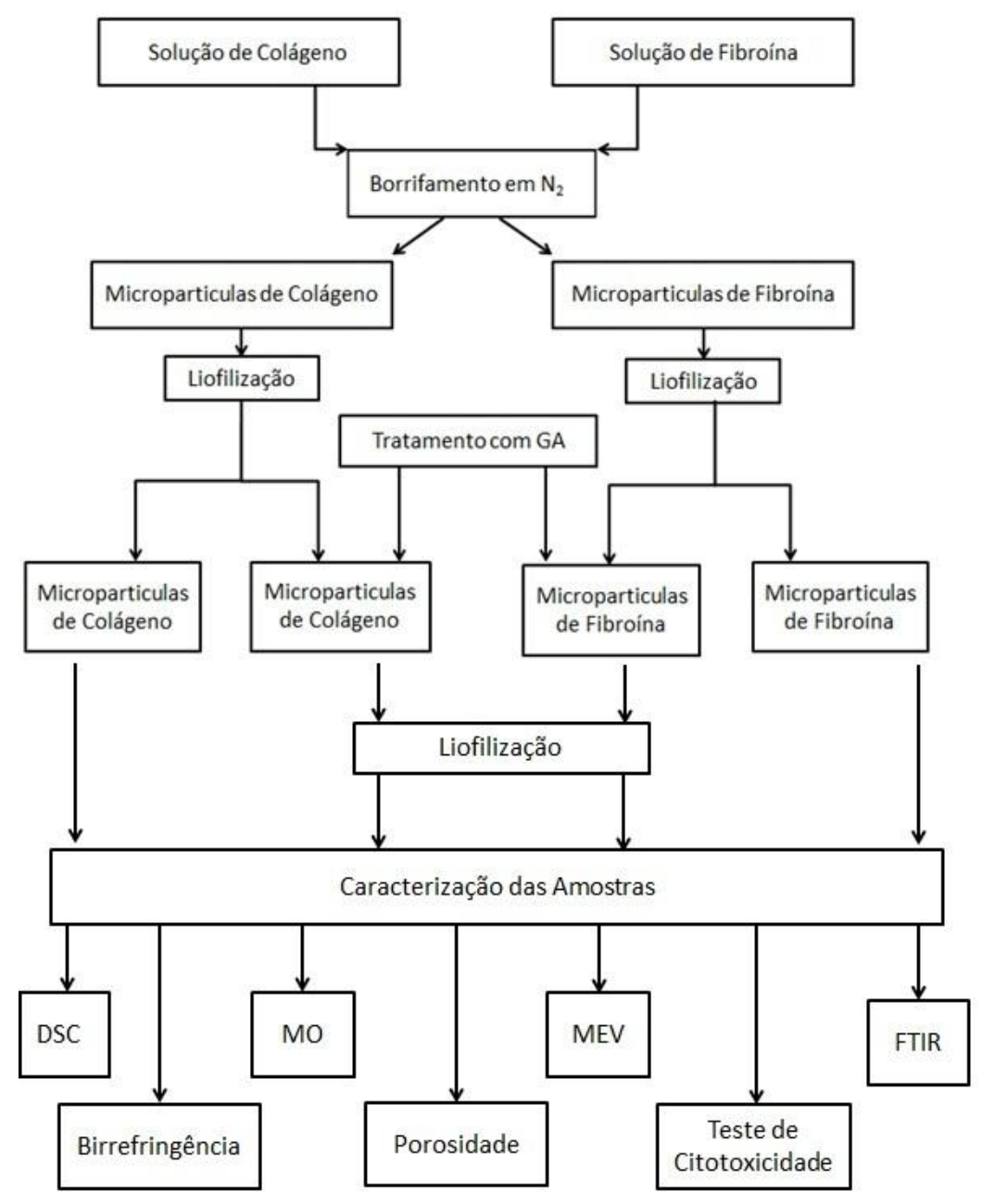

Figura 7. Fluxograma do delineamento experimental. 


\subsection{1 - Preparação do Colágeno}

Para a obtenção do colágeno, foi utilizada serosa porcina, camada mais externa do intestino delgado de suínos, que foi tratada com uma solução alcalina na presença de sais: $\mathrm{Ca}(\mathrm{OH})_{2}, \mathrm{KOH}, \mathrm{NaOH}, \mathrm{Na}_{2} \mathrm{SO}_{4}, \mathrm{KCl}, \mathrm{CaSO}_{4}$ e $\mathrm{NaCl}$ durante 72 h (GOISSIS, PLEPIS, ROCHA, 1994). Após isso, o colágeno foi homogeneizado em ácido acético pH 3,5 com mixer, filtrado em peneira de plástico de 49 mesh e armazenado sob refrigeração.

\subsection{2 - Preparação da Fibroína de Seda}

Os casulos dos bichos da seda utilizados nos experimentos foi cedido pelo sericultor Hélio Utsugai, de Bastos-SP.

\subsubsection{1 - Remoção da Sericina das Fibras dos Casulos do Bicho da Seda}

Para remover a sericina das fibras, a cada $6 \mathrm{~g}$ de casulo do bicho da seda foram tratadas em $2 \mathrm{~L}$ de solução aquosa em ebulição de $\mathrm{Na}_{2} \mathrm{CO}_{3}$ à concentração de $4,24 \mathrm{~g} \mathrm{~L}^{-1}$, durante 30 min, (Fig.8) (LI et al., 2002). Ao final, as fibras foram enxaguadas em $1 \mathrm{~L}$ de água destilada, por $5 \mathrm{~h}$, três vezes e em seguida secos na estufa a $40^{\circ} \mathrm{C}$ por $24 \mathrm{~h}$. 


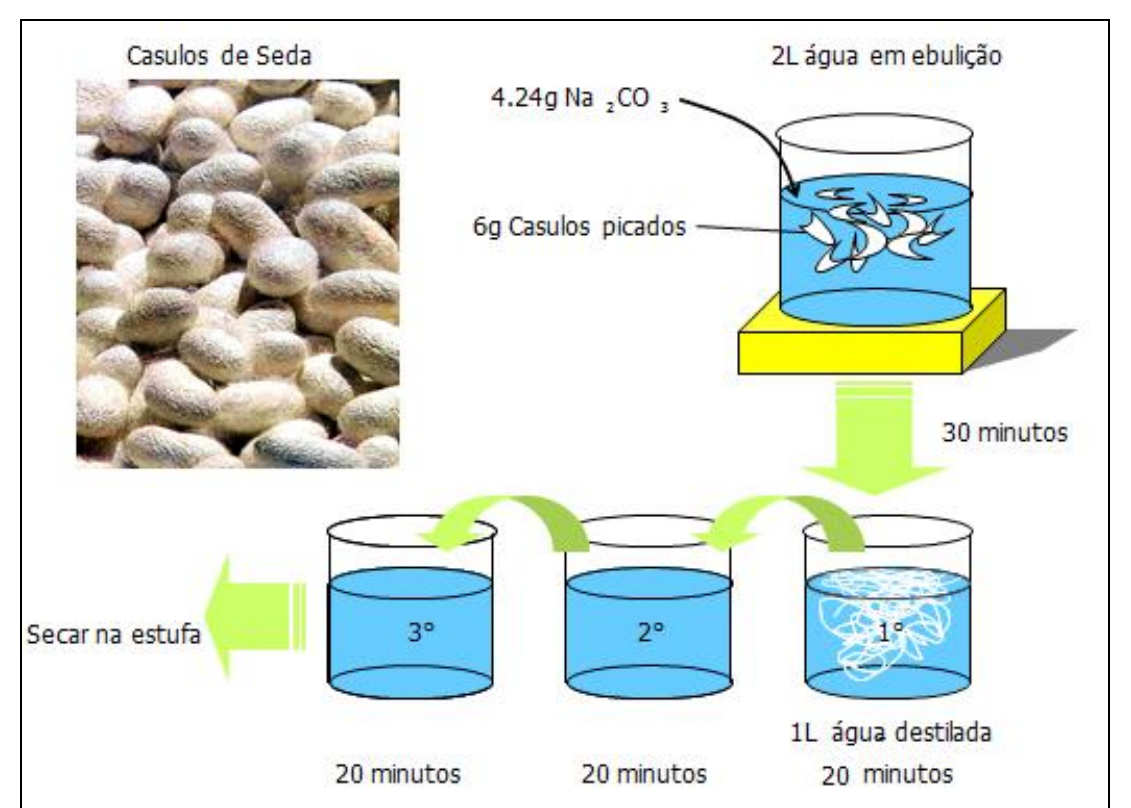

Figura 8. Processo de purificação da fribroína. Fonte: Xiaohui et al., 2008

\subsubsection{2 - Preparação da Solução de Fibroína}

Com a remoção da sericina, as fibras secas em estufa foram picotadas no moinho de facas, Tecnal modelo TE - 631/2, com o intuito de facilitar sua dissolução. adicionou-se 100 mL de solução ternária de $\mathrm{CaCl}_{2}-\mathrm{CH}_{3} \mathrm{CH}_{2} \mathrm{OH}-\mathrm{H}_{2} \mathrm{O}$ (1:2:8 moles) e a suspensão obtida era mantida a $60{ }^{\circ} \mathrm{C}$ em banho termostatizado até dissolução completa (XIAOHUI et al., 2008), como representado na Figura 9.

Após dissolução completa da fibroína, a solução foi colocada em tubo de diálise de celulose, com limite de exclusão de 16000 Da, e dialisada contra água. A água da diálise era trocada duas vezes ao dia, esse procedimento repetiu-se por três dias. 


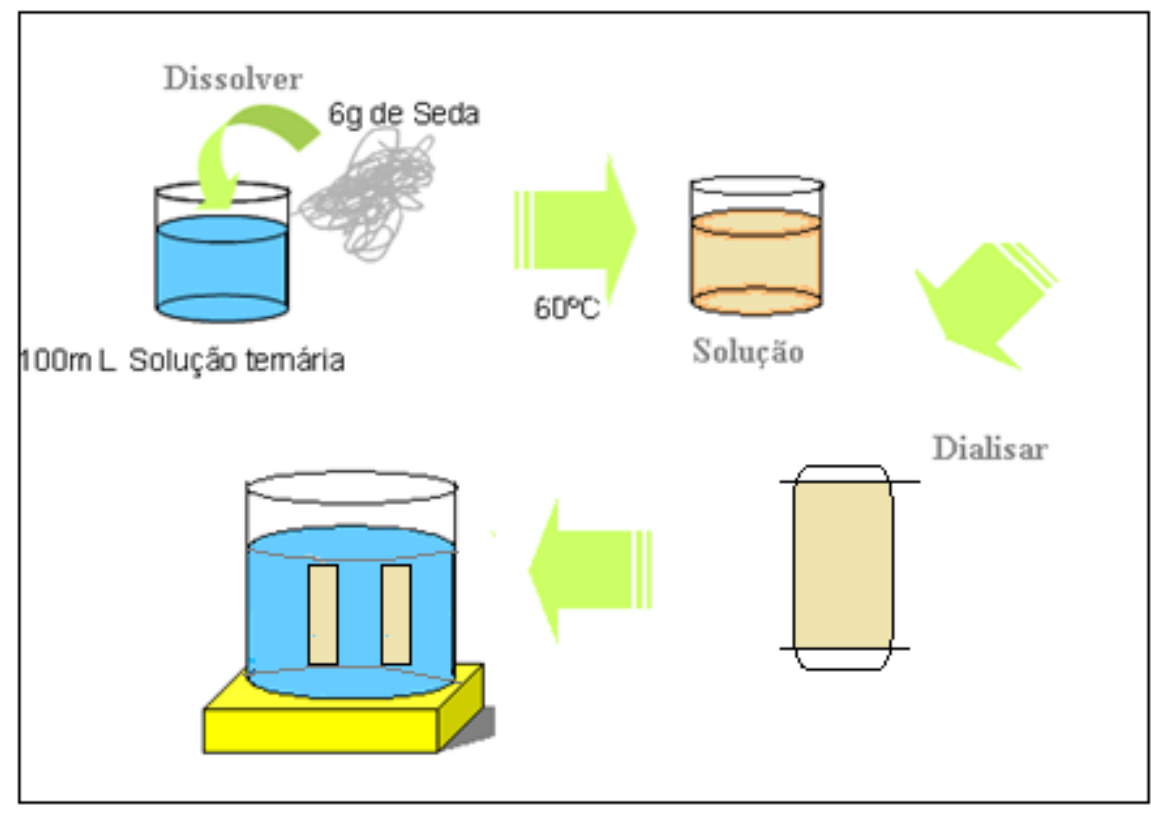

Figura 9. Processo de solubilização e diálise da fribroína. Fonte: Xiaohui et al., 2008

A diálise é um processo de separação por difusão de moléculas através dos poros de uma membrana semipermeável. Essa transferência de moléculas, solventes ou íons, ocorre por diferença de concentração entre as soluções em contato com a membrana com tendência de igualar os potenciais químicos, ou concentrações, resultando assim, em uma solução de fibroína mais pura retirando o máximo de cloreto de cálcio e EtOH.

\subsubsection{3 - Preparação das Micropartículas de Fibroína de Seda e Colágeno}

Depois de dialisada, a solução de fibroína de seda a $0,5 \%(\mathrm{~m} / \mathrm{m})$ foi borrifada, pelo pulverizador de vidro desenvolvido pelo grupo de pesquisa do Instituto de Química de São Carlos-USP (Fig.10), direto em nitrogênio líquido $\left(\mathrm{N}_{2}\right)$ a uma pressão menor que 120psi, para a formação das micropartículas, as quais foram posteriormente liofilizadas sob as seguintes condições: temperatura $-54{ }^{\circ} \mathrm{C}$ e pressão $79 \mu \mathrm{m} \mathrm{Hg}$ em um liofilizador, marca Edwards até atingirem pesos constantes.As micropartículas de colágeno foram obtidas a partir de soluções, com concentração $0,3 \%(\mathrm{~m} / \mathrm{m})$, usando o mesmo processo descrito acima para as micropartículas de fibroína. 


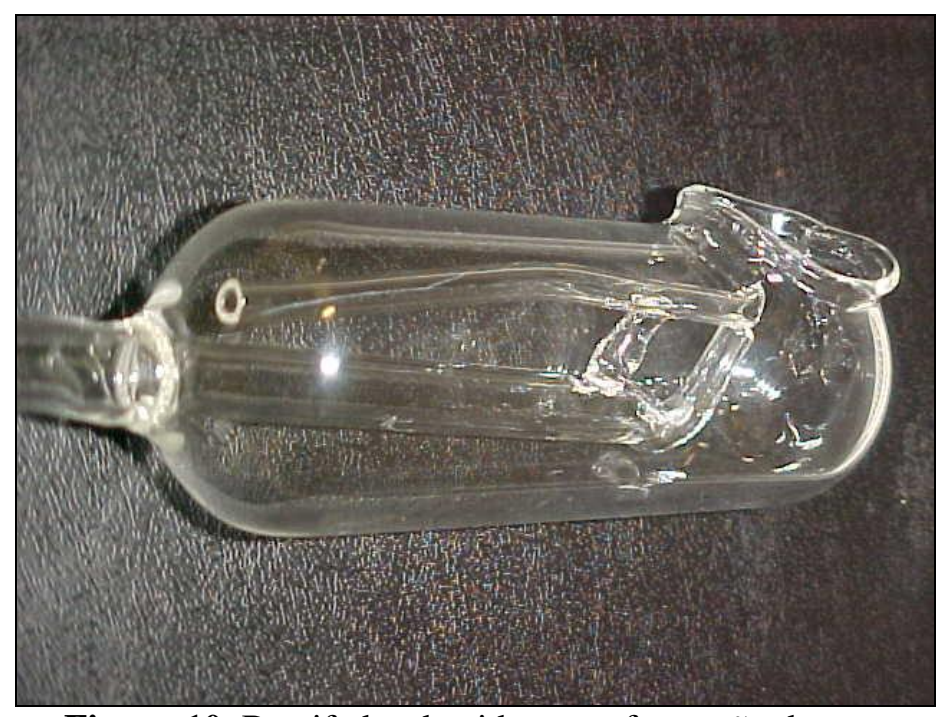

Figura 10. Borrifador de vidro para formação de micropartículas de colágeno e fibroína.

\section{3 - Tratamentos com Glutaraldeído (GA)}

Para um estudo comparativo, na caracterização do material, após obter as micropartículas de colágeno e de fibroína, uma porção das amostras foram tratadas com glutaraldeído (GA) a 0,05\% (m/m) em acetona, por $30 \mathrm{~min}$., posteriormente lavadas com água destilada abundantemente e em seguida congeladas em $\mathrm{N}_{2}$ liquido e liofilizadas.

Ao final do processo as micropartículas foram esterilizadas com óxido de etileno e para posterior utilização.

\section{4 - Caracterizações das Micropartículas de Colágeno e Fibroína}

\subsection{1 - Análise Térmica por Calorimetria Exploratoria Diferencial ( DSC )}

As curvas de DSC obtidas no equipamento de DSC-2010 da TA Instruments, do IQSC-SP, calibrado com padrão de índio e taxa de aquecimento de $10{ }^{\circ} \mathrm{C} \mathrm{min}^{-1} \mathrm{com}$ varredura de temperatura de 25 a $120{ }^{\circ} \mathrm{C}$ para colágeno e de 25 a $450{ }^{\circ} \mathrm{C}$ para fibroína, com amostras de aproximadamente $10 \mathrm{mg}$ colocadas em panelas de alumínio e aquecidas sob atmosfera de $\mathrm{N}_{2}$. 


\subsection{2 - Microscopia Eletrônica de Varredura ( MEV )}

As amostras foram colocadas nos suportes porta-amostras metálicas e recobertas com uma fina camada de ouro $(20 \mathrm{~nm})$ em um metalizador Balsers modelo SDC 050. As fotomicrografias foram obtidas em equipamento LEO-440 (LEO Electron Microscopy Ltda), utilizando um feixe de elétrons de $20 \mathrm{keV}$, com um detector Oxford (Oxford Instruments Inc.), o equipamento pertence à CAQ/IQSC-USP.

\subsection{3 - Microscopia de Luz}

\section{a) Preparação das lâminas}

Com a finalidade de avaliar a estrutura interna das micropartículas, montaram-se lâminas com cortes verticais do material. Os procedimentos de preparo e fixação foram os mesmos para todas as micropartículas de colágeno e fibroína, tratados ou não com GA.

Inicialmente, fixadas em formaldeído a $10 \%(\mathrm{v} / \mathrm{v})$ em tampão fosfato $0,1 \mathrm{~mol} \mathrm{~L}^{-1} \mathrm{pH}$ 7,2, para posterior inclusão em resina metacrilato (Historesin®). Após a inclusão do material nos blocos, os cortes histológicos foram feitos no Micrótomo da marca RM 2165 da Leica (Figura 11), na espessura de $3 \mu \mathrm{m}$, no Departamento de Morfologia do Instituto de Biociências de Botucatu, UNESP.

Para corar os cortes utilizou-se eosina, deixada imersa por 3 min e lavada em água corrente por 5 min. Para montar a lâmina usou-se cola permount e lamínula que foi seca em temperatura ambiente. 


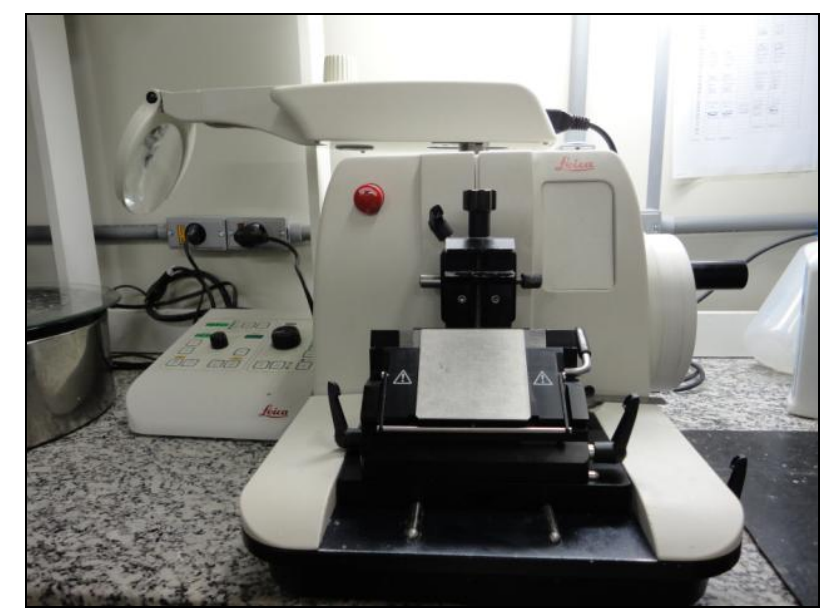

Figura 11. Micrótomo RM 2165 da Leica.

\section{b) Microscopia Ótica (MO)}

Para a observação das amostras no microscópio ótico, as micropartículas de colágeno e fibroína reticuladas ou não foram fixadas em formaldeído a $10 \%(\mathrm{v} / \mathrm{v})$ em tampão fosfato $0,1 \mathrm{~mol} \mathrm{~L}^{-1} \mathrm{pH} \mathrm{7,2,} \mathrm{coradas} \mathrm{com} \mathrm{eosina.} \mathrm{As} \mathrm{fotomicrografias} \mathrm{foram} \mathrm{feitas} \mathrm{em} \mathrm{um} \mathrm{analisador}$ de imagens Leica Q-Win Standard Versão 3.1.0 aclopado ao microscópio Leica DM, no Departamento de Morfologia, Instituto de Biociências de Botucatu, Universidade Estadual Paulista.

\subsection{3 - Microscopia Ótica de Birrefringência}

Para obtenção das fotomicrografias birrefringentes, utilizou-se o microscópio de fluorescência Zeiss aclopado à câmera digital Olympus, as micropartículas de colágeno e fibroína reticuladas ou não, fixadas em formaldeído a $10 \%(\mathrm{v} / \mathrm{v})$ em tampão fosfato $0,1 \mathrm{~mol}$ $\mathrm{L}^{-1} \mathrm{pH} 7,2$, coradas com eosina. As análises foram feitas no Departamento de Morfologia, Instituto de Biociências de Botucatu, Universidade Estadual Paulista. 


\subsection{4 - Espectroscopia no Infravermelho (FTIR)}

Para a análise no infravermelho, prepararam-se pastilhas de $\mathrm{KBr}$ por prensagem de espessura fina, previamente seco em estufa a $100^{\circ} \mathrm{C}$, para garantir o peso constante. $\mathrm{O}$ controle constituiu somente de $\mathrm{KBr}$ e as demais amostras compostas por $\mathrm{KBr}$ com: 1) micropartículas de colágeno, 2) micropartículas de colágeno reticulado, 3) micropartículas de fibroína e 4) micropartículas de fibroína reticulada.

O espectro de FTIR foi obtido em um espectrofotômetro BOMEM MICHELSON SERIES num intervalo de 400 a $4000 \mathrm{~cm}^{-1}$, com resolução de $4 \mathrm{~cm}^{-1}$ (CAQ/IQSC-USP).

\subsection{5 - Percentual de Absorção de Água das Micropartículas}

Inicialmente, as amostras foram liofilizadas até obter peso constante e então pesadas cerca de 10mg de cada amostra - micropartículas de colágeno, de fibroína, ambas reticuladas e não reticuladas - e colocadas separadamente em frascos contendo água destilada por períodos de tempo de 1, 2, 3, 5, 7, 10, 15, 20, 30, 60 e 90 min., o excesso de água foi retirado com papel de filtro e feito a pesagem.

O percentual de absorção de água \% foi calculada pela equação (1) e realizada uma média de 3 valores.

$$
\%=\frac{(\text { peso das microparticulas hidratadas })-(\text { peso das microparticulas liofilizad as })}{(\text { peso das microparticulas liofilizad as })} \times 100
$$

\section{5 - Teste de Citotoxicidade}

O meio de cultura utilizado na expansão das CTMs foi o MesenPro (Invitrogen) com $2 \%$ de soro fetal bovino (SFB), L-glutamina (Sigma-Aldrich) e penicilina/estreptomicina (Gibco) e acondicionadas em incubadoras de cultivo com atmosfera úmida contendo $5 \%$ de 
$\mathrm{CO}_{2}$ a $37^{\circ} \mathrm{C}$. O repique das células foi realizado ao se atingir uma subconfluência celular de aproximadamente $80 \%$. Para esse procedimento foi utilizada a enzima de dissociação TrypLETM $1 x$ (Invitrogen).

\subsection{1 - Microcarregadores}

As micropartículas de colágeno e fibroína tratadas ou não com GA, desenvolvidas neste estudo, foram colocadas em microplacas de 96 poços na presença de CTMs, a fim de avaliar sua biocompatibilidade, adesão e taxa proliferativa.

Também se utilizou o microcarregador comercial Cultispher-S (Percell Biolytica, Suécia) macroporoso, de diâmetro entre 130-380 $\mu \mathrm{m}$ com matriz de gelatina reticulada que pode ser dissolvida com enzimas proteolíticas que resulta na recuperação de células viáveis.

\subsection{2 - Cultivo Celular}

Realizaram-se ensaios de citotoxicidade dos materiais utilizados, com a finalidade de diminuir a presença de contaminantes que possam interferir de maneira negativa no desenvolvimento da cultura celular.

Para tanto, a linhagem celular foi cultivada em frascos de cultura celular (frascos T) com área superficial de $25 \mathrm{~cm}^{2}$ e de $75 \mathrm{~cm}^{2}$ de poliestireno (TPP, EUA). Após a expansão necessária, as CTMs foram transferidas para microplacas de 24 poços a uma concentração de $1 \times 10^{5}$ cél $\mathrm{mL}^{-1}$, juntamente com micropartículas de colágeno e fibroína, ambas tratadas ou não com GA a fim de avaliar a citotoxicidade dos biomaterias. Para fins comparativos, o mesmo procedimento foi realizado com o microcarregador Cultispher-S (Percell Biolytica, Suécia) e um cultivo controle sem a presença de micropartículas, em que as células foram inoculadas diretamente sobre a microplaca. Esses cultivos foram mantidos em incubadora com $5 \%$ de $\mathrm{CO}_{2}$ a $37^{\circ} \mathrm{C}$ durante o período de $72 \mathrm{~h}$. 


\subsection{3 - Análise de Viabilidade Celular}

Para a análise de viabilidade e densidade celular, usou-se o método de exclusão do corante azul de Tripan em hemacitômetro (DOYLE \& GRIFFITHS, 1998). Foram contados 16 quadrantes (8 quadrantes/câmara) para diminuir os erros de contagem. A média e o desvio padrão das medidas de densidade e viabilidade celular foram determinados considerando 4 eventos de contagem, cada evento representado pela contagem de 4 quadrantes.

A densidade celular foi determinada pela contagem na câmara de Neubauer. Para isso, retiraram-se amostras celulares de $20 \mu \mathrm{L}$ de cada poço analisado e, em seguida, acrescentou $20 \mu \mathrm{L}$ de uma solução de EtOH com azul de Tripan a 0,4\% (m/v) preparados previamente. Já o kit baseado no MTT ou Brometo de 3-[4,5-dimetiltiazol-2-il]-2,5-difeniltetrazólio, utilizado para determinar indiretamente a densidade celular dos cultivos, por espectrofotometria, em função da atividade mitocondrial das células vivas. Para obter o valor da absorbância das amostras obtidas pelo método do MTT, foi usada a leitora de microplacas Multiskan FC da Thermo Scientific (EUA) com filtro de $570 \mathrm{~nm}$.

Para a aplicação do método baseado no MTT foi necessária a preparação de uma curva de calibração a partir de uma densidade celular previamente conhecida em função da absorbância, antes de iniciar os experimentos de expansão de CTMs.

Para a reação, usou-se uma amostra de $200 \mu \mathrm{L}$, à qual foram adicionados $10 \%$ do volume da amostra à solução reagente do MTT e, em seguida, homogeneizada e mantida na incubadora de $\mathrm{CO}_{2}$ a $37^{\circ} \mathrm{C}$ por $4 \mathrm{~h}$. Após esse período de reação, uma solução de isopropanol foi adicionada para a solubilização dos cristais de formazan azul escuro formado no interior das células vivas. Em seguida, a amostra foi centrifugada a $1500 \mathrm{rpm}$ para a sedimentação dos microcarregadores e dos restos celulares, e o sobrenadante analisado, em triplicata, pela leitura no espectrofotômetro de placas Elisa, usando o filtro de comprimento de onda de 570nm. A Figura 12 apresenta a reação envolvida no método descrito. 
<smiles>Cc1nc(-[n+]2nc(-c3ccccc3)nn2-c2ccccc2)sc1C</smiles>

Brometo de 3-(4,5-dimetilazol-2-il)-2,5-difeniltetrazólio (Amarelo)<smiles>Cc1nc(NN/C(=N\Nc2ccccc2)c2ccccc2)sc1C</smiles>

Formazan

(Azul Escuro)

Figura 12 - Representação da reação enzimática em que se fundamenta o método do MTT.

Para a quantificação das células viáveis pelo método do MTT e para células, as medidas de absorbância (métodos colorimétricos) foram realizados testes em triplicata. Desta forma, a média e o desvio padrão foram calculados para cada uma das amostras.

\section{6 - Testes de Citotoxicidade}

Após a expansão da linhagem celular, em frascos $\mathrm{T}$ com meio de cultura MesenPro (Invitrogen), transferiu-se uma densidade celular de $1 \times 10^{5}$ células por poço das microplacas previamente esterilizada e siliconizada com Sigmacote (SIGMA-ALDRICH, EUA), um composto à base de silicone que forma um filme neutro e hidrofóbico, utilizado para impedir a adesão das células, das micropartículas e microcarregadores no fundo e paredes das microplacas.

Para realizar os testes citotoxicos, os poços designados controle com apenas células e meio de cultura e poços contendo células, meio de cultura e 1 g. $1^{-1}$ de microcarregadores Cultispher S (Percell Biolytica, Suécia), foram comparados com os poços em que havia células, meio de cultura e 1 g..$^{-1}$ do material a ser analisado: micropartículas de colágeno e fibroína, tratadas ou não com GA. O teste foi feito em triplicata para assegurar a confiabilidade do experimento.

Após a inoculação, as microplacas mantiveram-se na incubadora de $\mathrm{CO}_{2}$, com umidade e temperatura controladas, durante um período de $72 \mathrm{~h}$ para o desenvolvimento celular. Todo procedimento foi realizado em câmara de fluxo laminar asséptica Sterilgard III, 
classe II, da Baker Company (EUA), modelo SG403/SG603, provida de lâmpada germicida UV.

Para analisar a citotoxicidade, a adesão e o crescimento celular nas micropartículas, no microcarregador e poços controle, as células foram coradas a partir do método do MTT como descrito anteriormente. 
5. RESULTADOS E DISCUSSÃO 


\section{1 - Calorimetria Exploratória Diferencial (DSC)}

Ao observar a curva DSC das micropartículas de colágeno (Fig.13), nota-se a transição endotérmica referente à desnaturação da proteína, que é a transição da tripla hélice para uma forma desordenada quando o colágeno é aquecido. Este aquecimento provoca a quebra de ligações fracas intramoleculares em que a proteína passa de uma estrutura organizada a uma forma desorganizada chamada gelatina.

As micropartículas de colágeno que não foram reticuladas, nota-se que a temperatura de desnaturação é de $52,8^{\circ} \mathrm{C}$, na curva de DSC enquanto aquelas tratadas com GA apresentaram temperatura de $67,7{ }^{\circ} \mathrm{C}$. Esta variação na temperatura de desnaturação, de aproximadamente $15{ }^{\circ} \mathrm{C}$, é resultado do aumento no grau de reticulação proporcionado pelo glutaraldeído. A reticulação pode ser atribuída à formação de ligações cruzadas do tipo base de Schiff entre o GA e $\varepsilon$-amino grupos de lisina e hidroxilisina da matriz de colágeno (GOISSIS; BRAILE; GIGLIOTI, 1999), que interligam as cadeias da tripla hélice.

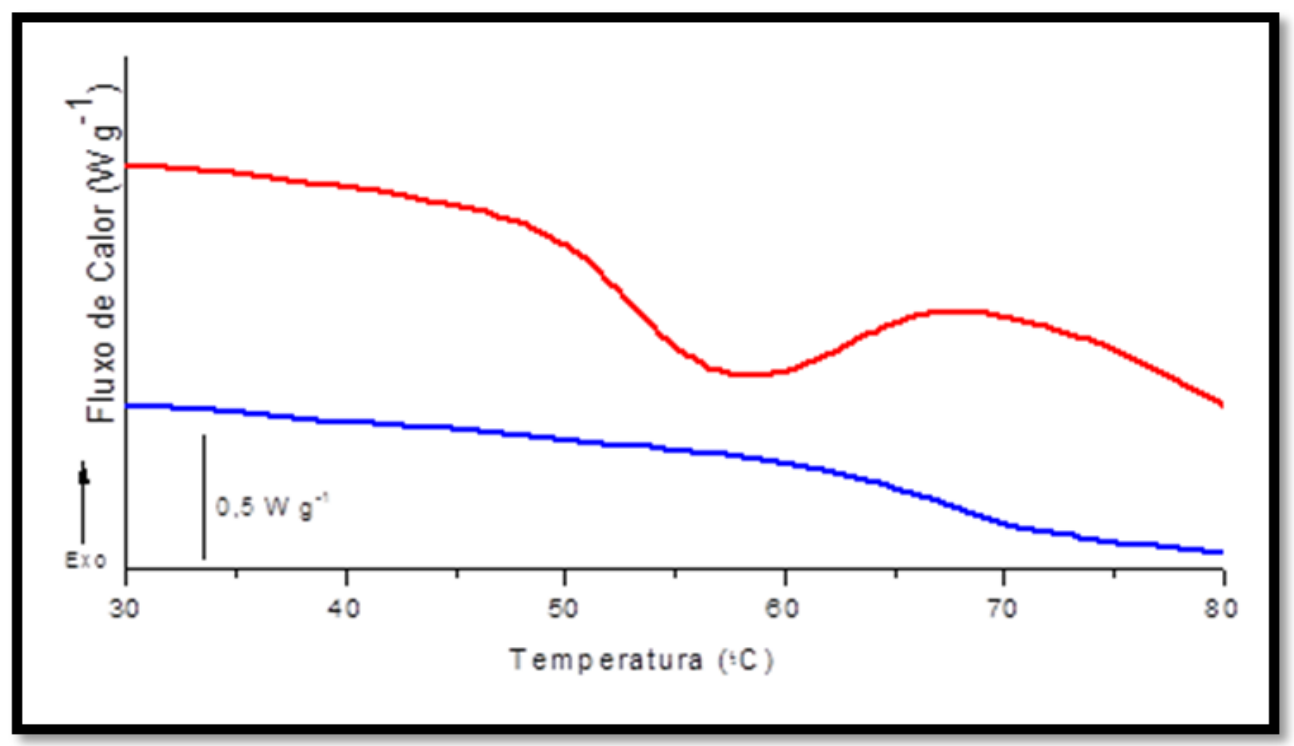

Figura 13. Curva DSC das micropartículas de Colágeno: (- - Não Reticulado (一-) Reticulado.

Nas curvas de DSC das micropartículas de fibroína não reticuladas com GA, apresentaram-se picos endotérmicos de $97,2^{\circ} \mathrm{C}$ e $111,0^{\circ} \mathrm{C}$ relacionados à perda de água do material. As temperaturas de $284,7^{\circ} \mathrm{C}$ e $293,7^{\circ} \mathrm{C}$ indicam a decomposição da fibroína, este pico de degradação é característico para materiais derivados da seda com 
configuração secundária folha- $\beta$ (FREDDI, et al., 1999). Porém, quando submetidas ao agente reticulante, a temperatura ficou por volta de $288,9^{\circ} \mathrm{C}$ e $300,9^{\circ} \mathrm{C}$ (Fig. 14 ), sugerindo que o aumento na temperatura de decomposição pode ser devido às reticulações efetuadas pelo GA.

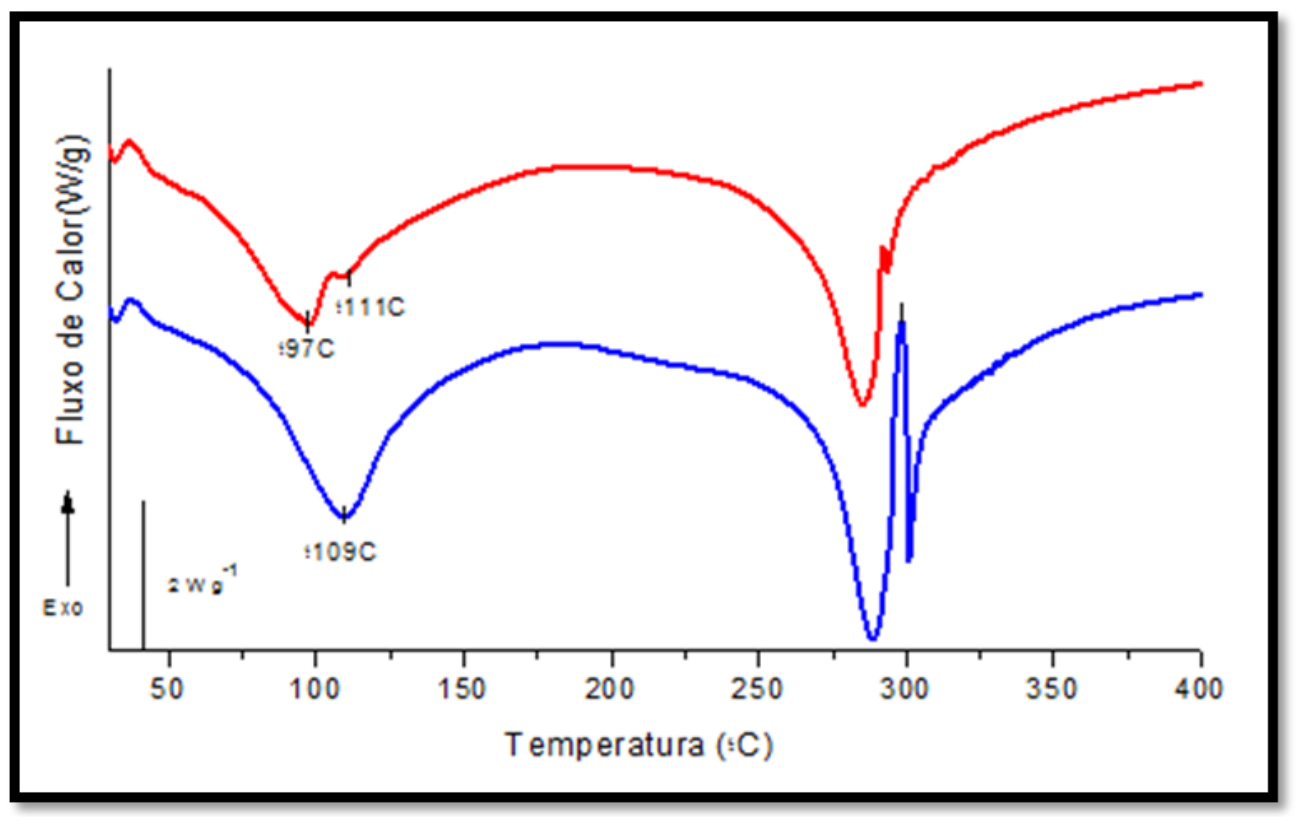

Figura 14. Curva DSC das micropartículas de Fibroína. (-—-) Não Reticulada (- - Reticulada.

A decomposição térmica da fibroína de seda é influenciada principalmente pelo grau de orientação molecular da proteína (TSUKADA, 1996). Fibras bem orientadas normalmente apresentam pico de decomposição localizado acima de $300^{\circ} \mathrm{C}$, enquanto que materiais de fibroína da seda com configuração $\beta$-folha não orientada apresenta picos de decomposição entre $290^{\circ} \mathrm{C}$ e $295^{\circ} \mathrm{C}$. Em contraste, os materiais amorfos de fibroína de seda apresentariam picos de decomposição abaixo de $290^{\circ} \mathrm{C}$ (FREDDI, 1999).

É importante ressaltar, que as micropartículas analisadas foram liofilizadas, o que pode ter ocasionado formação de mais estruturas de $\beta$-folha através da desidratação das cadeias moleculares da fibroína de seda. 


\section{2 - Microscopia Eletrônica de Varredura (MEV)}

Para efeito de estudo e comparação no desenvolvimento do material, é de grande relevância a visualização da estrutura das micropartículas observando a forma, o tamanho, a rugosidade e porosidade das mesmas. Nas fotomicrografias obtidas por MEV, observam-se as superfícies das micropartículas de colágeno e fibroína e as mudanças possivelmente ocorridas após a reticulação com GA.

A Figura 15 mostra as fotomicrografias das micropartículas de colágeno sem reticulação, e a Figura 16 das micropartículas de colágeno tratadas com GA. Estas duas Figuras mostram que a reticulação induz à formação de rugosidades na superfície das micropartículas. A quantidade de rugosidade aumenta nas micropartículas de tamanho maior, pois sua superfície de contato é mais extensa, não observando-se alteração naquelas não reticuladas.

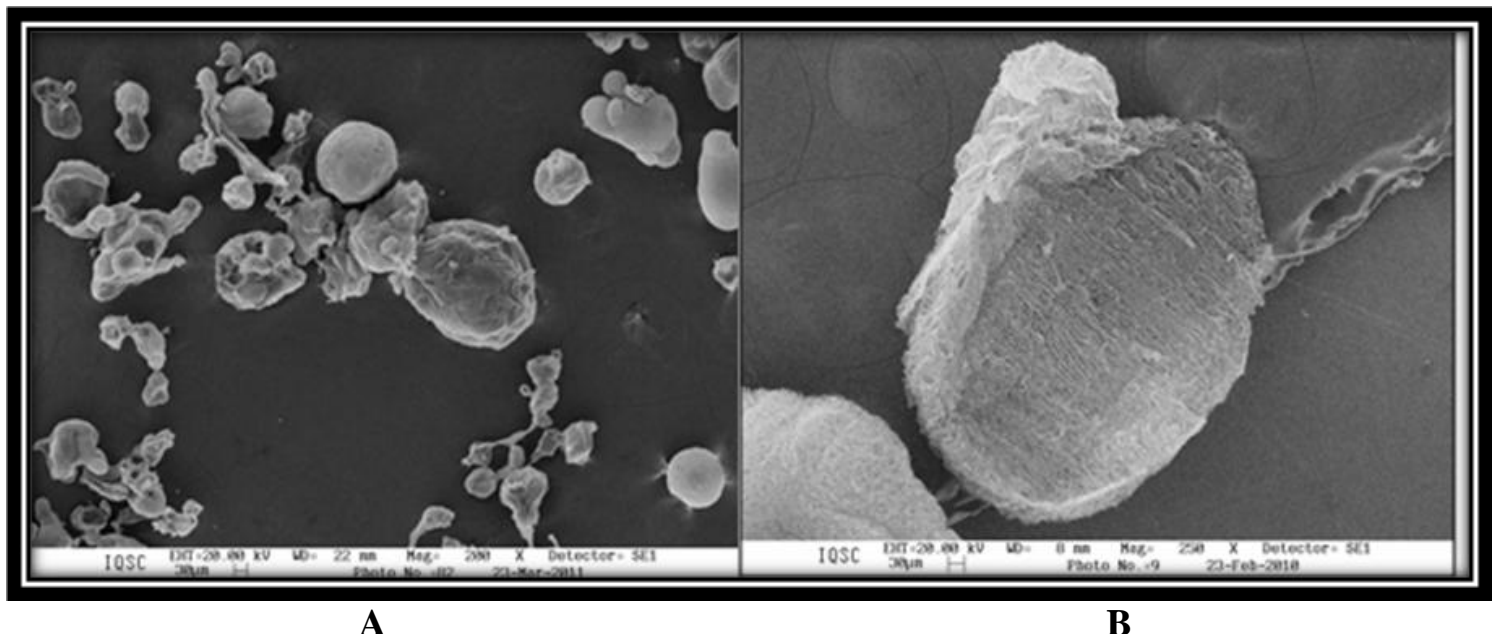

Figura 15. MEV das micropartículas de colágeno não reticulado. Aumento 200x e 250x. 


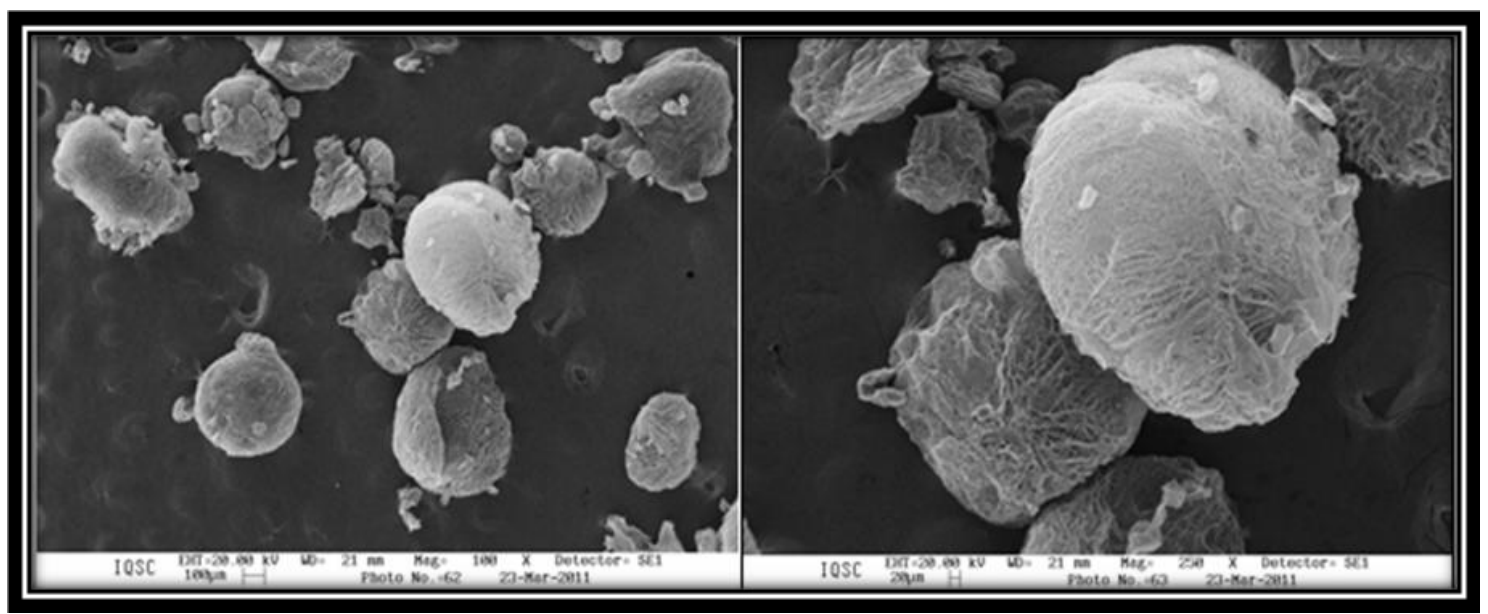

A

B

Figura 16. MEV das micropartículas de colágeno reticulada. Aumento 100x e 250x.

Na Figura 17 e 18, têm-se fotomicrografias das micropartículas de fibroína, em que as micropartículas não reticuladas apresentam uma superfície lisa, homogênea e com poucos poros. As micropartículas de fibroína reticuladas têm um maior número de poros presentes, bem como a presença de rugosidades. A técnica de liofilização em alto vácuo pode gerar materiais com alta porosidade e interconectividade entre os poros (MANDAL, KUNDU, 2009).

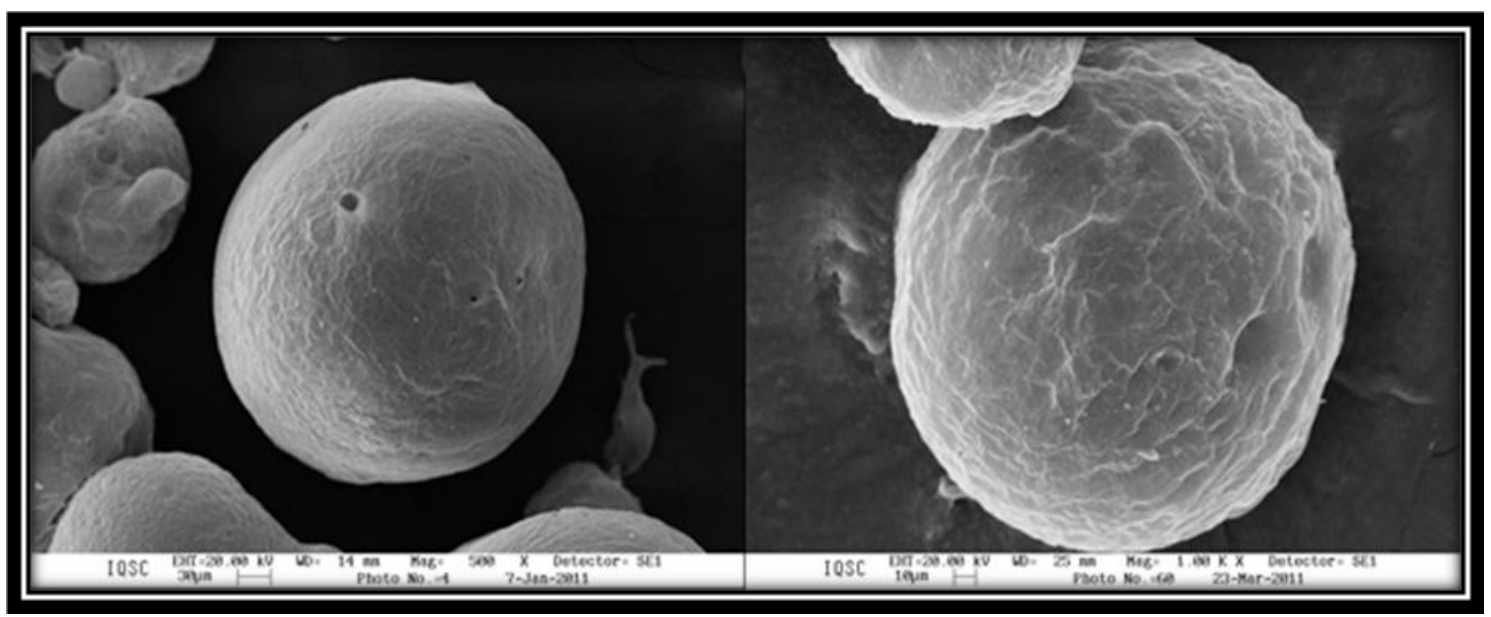

A

B

Figura 17. MEV das micropartículas de fibroína não reticulada. Aumento 500x e 1000x. 


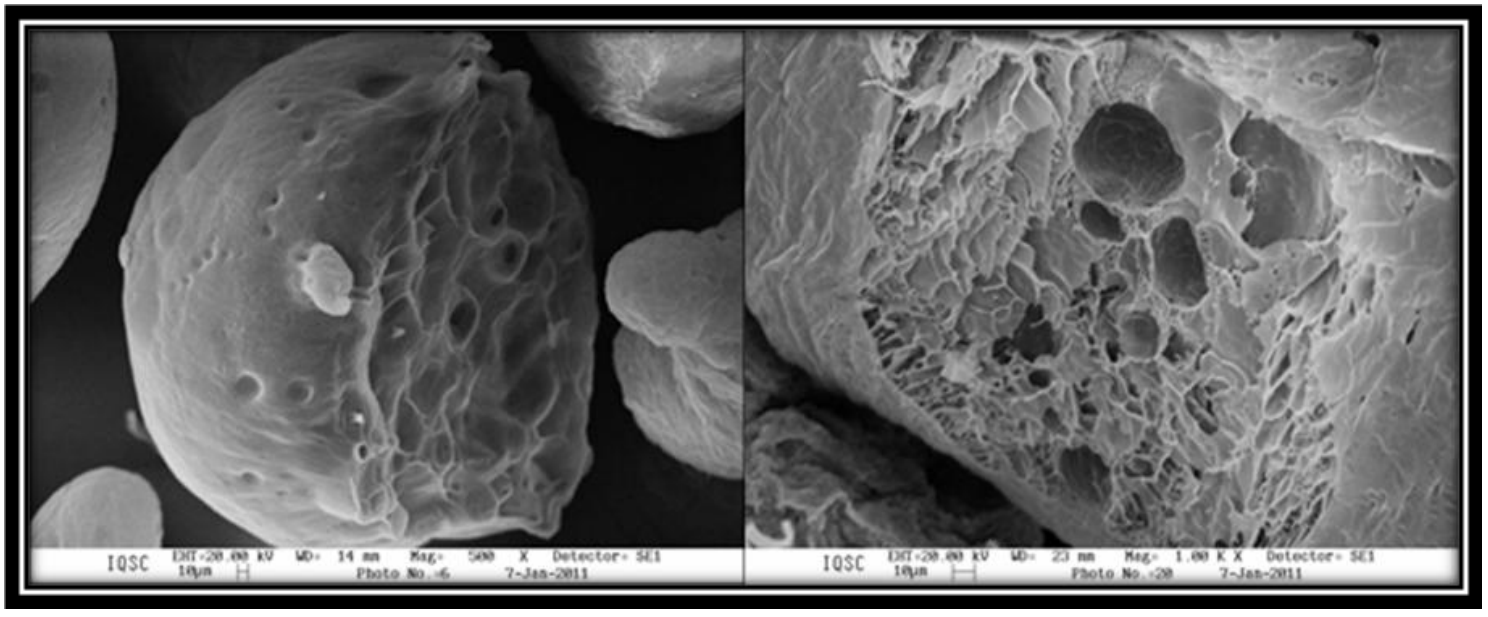

A

B

Figura 18. MEV das micropartículas de fibroína reticulada. Aumento 500x e 1000x.

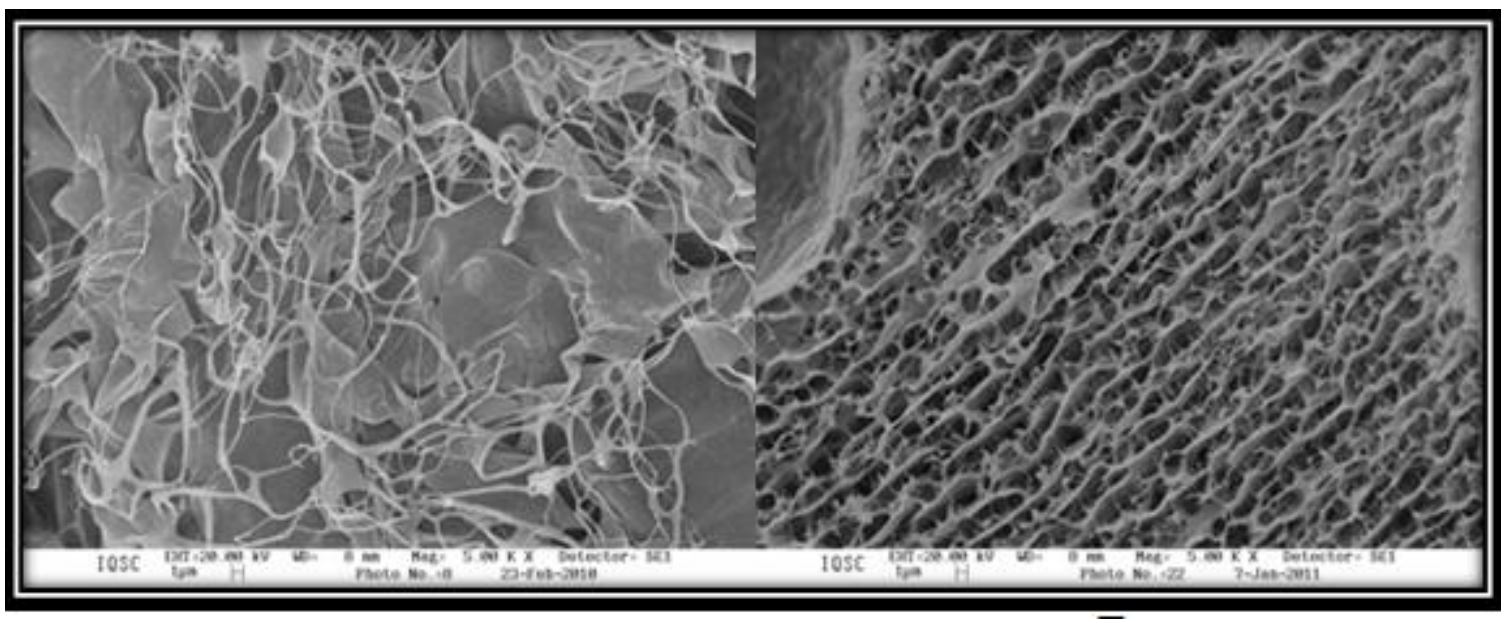

A

$\overline{\mathbf{B}}$

Figura 19. MEV do interior das micropartículas reticuladas: A) Colágeno e B) Fibroína. Aumento 500x.

Na Figuras 19 A e 19 B, observa-se o interior das micropartículas de colágeno e fibroína reticulados, respectivamente. Nota-se que há formação de fibras filamentosas e que estas se apresentam de formas mais orientadas na fibroína.

As micropartículas de fibroína encontram-se em um formato mais esférico que as de colágeno (Fig. 20 A e 20 B) e com tamanho entre 57,37 e 144,26 $\mu \mathrm{m}$ para o colágeno entre 58,53 e 163,41 $\mu$ m para fibroína, as medidas foram feitas no software de domínio público Imag J (site: www.superdownloads.com.br). 


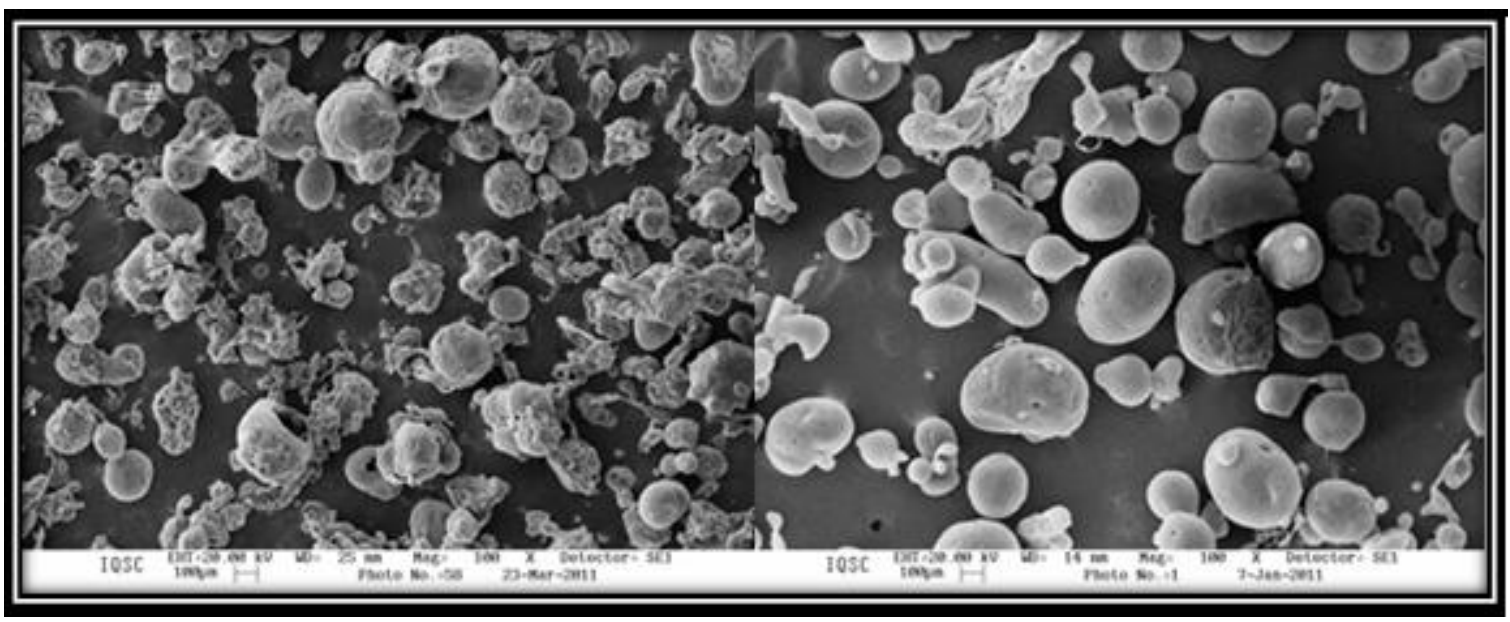

A

B

Figura 20: MEV das micropartículas reticuladas: A) Colágeno e B) Fibroína. Aumento 100x.

\section{3 - Microscopia de Luz}

A microscopia ótica mostra que a reticulação com GA das micropartículas de colágeno (Fig. 21 e 23) não reticuladas (Fig. 22 e 24) induzem à orientação das fibras de colágeno em forma radial, com feixes convergindo para o centro. $\mathrm{Na}$ solução de colágeno, mesmo usada a uma concentração de $0,3 \%$, observa-se a presença de fibras.

No caso das micropartículas de fibroína não reticulada (Fig. 25 e 27), há presença de rugosidades e poros que podem auxiliar no crescimento celular e até servir como pontos de ancoragem e difusão de íons (BEPPU et al., 2006), principalmente nas micropartículas de fibroína reticuladas (Fig.26 e 28), ou ainda crescimento de fungos nestes poros.

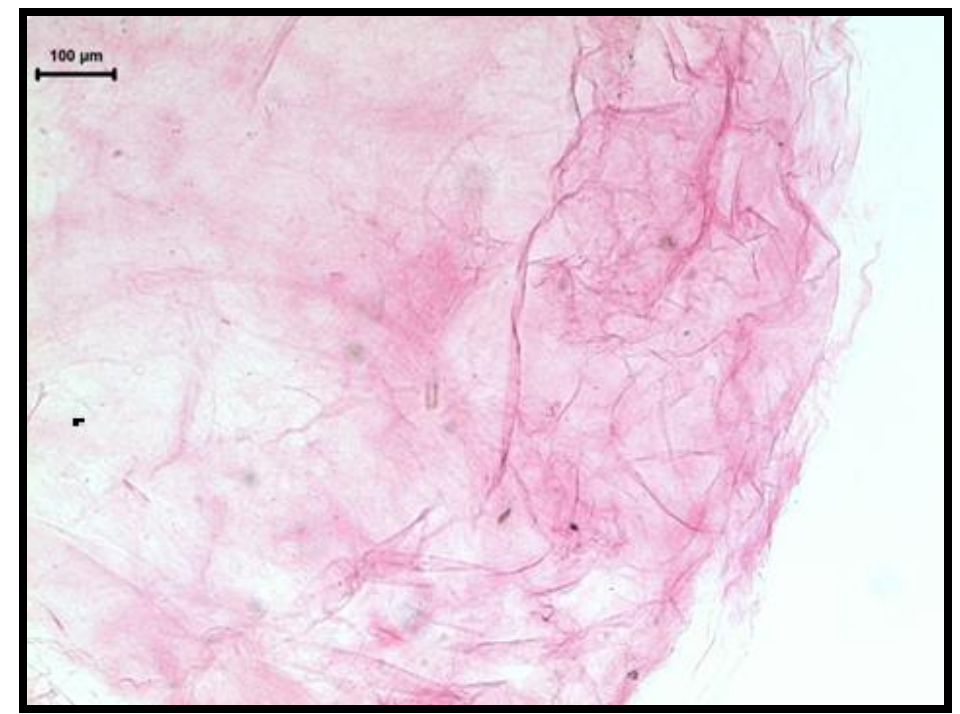

Figura 21. MO superficial do colágeno não reticulado (100x) 


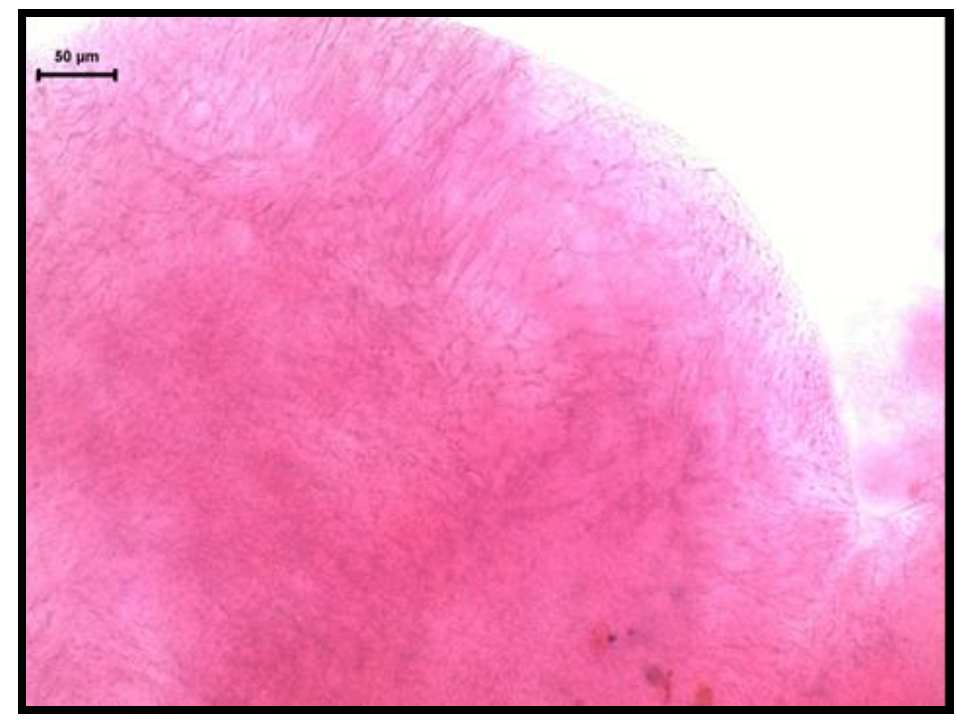

Figura 22. MO superficial do colágeno reticulado (100x)

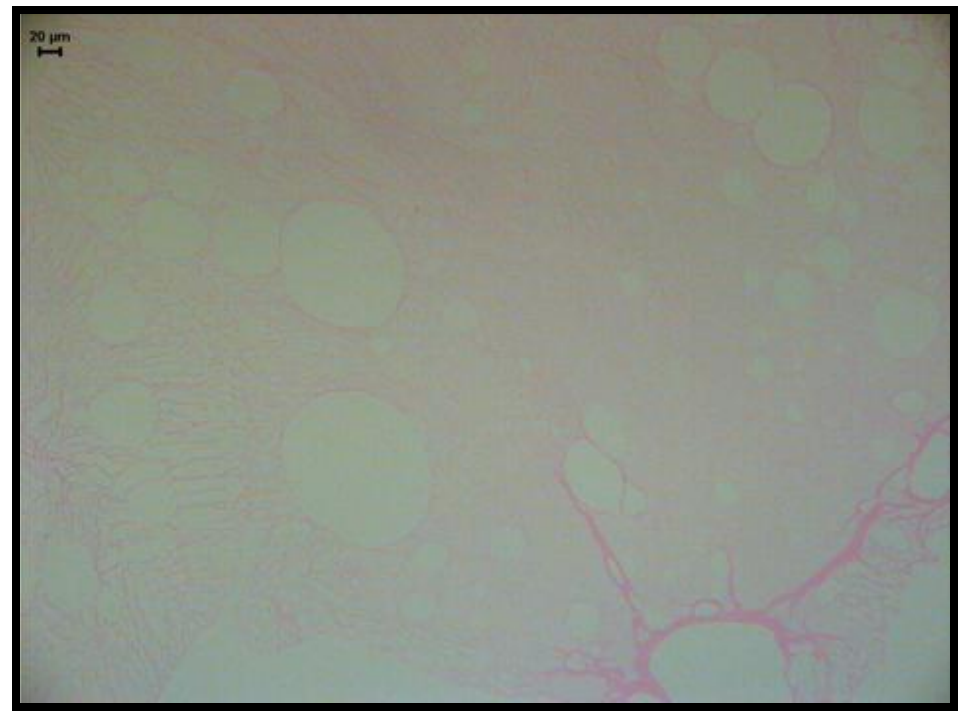

Figura 23. MO do corte das micropartículas de colágeno não reticulado (aumento de 100x). 


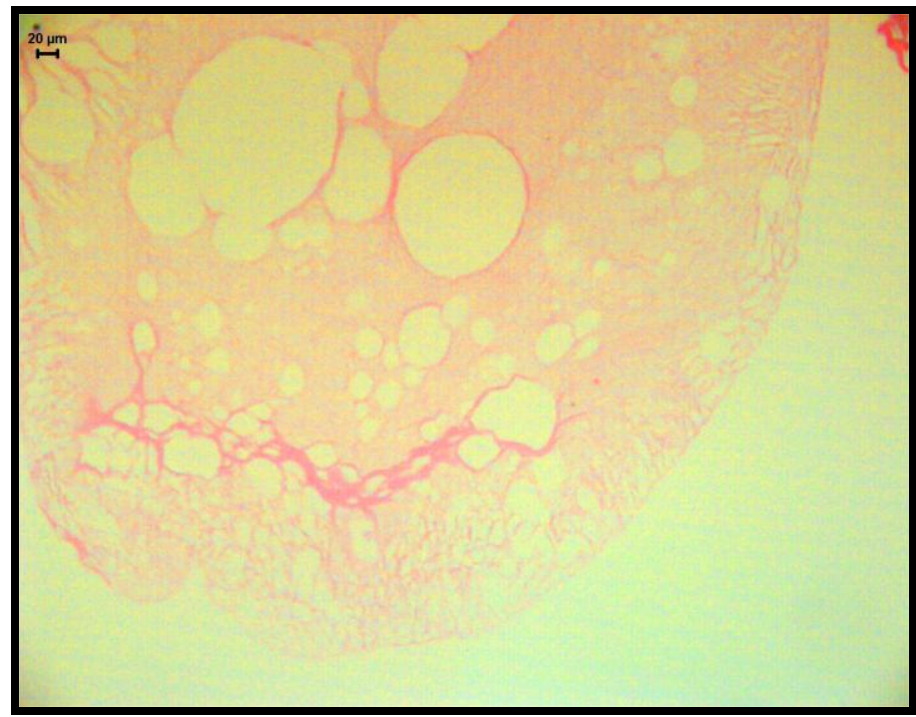

Figura 24. MO do corte das micropartículas de colágeno reticulado (aumento de 100x).

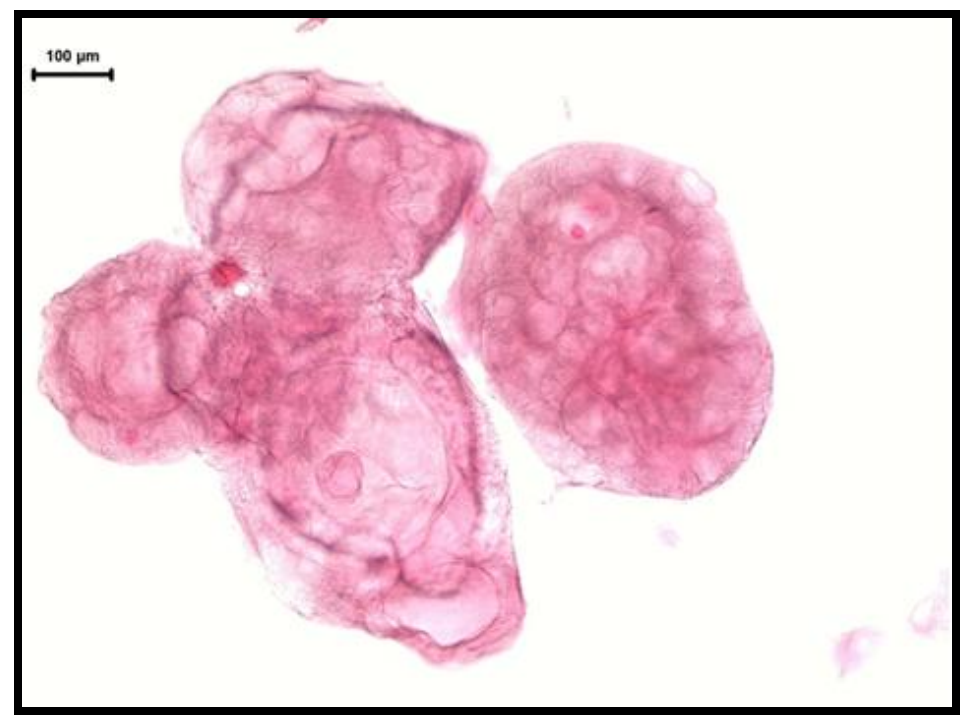

Figura 25. MO superficial da fibroína não reticulada (aumento de 100x). 


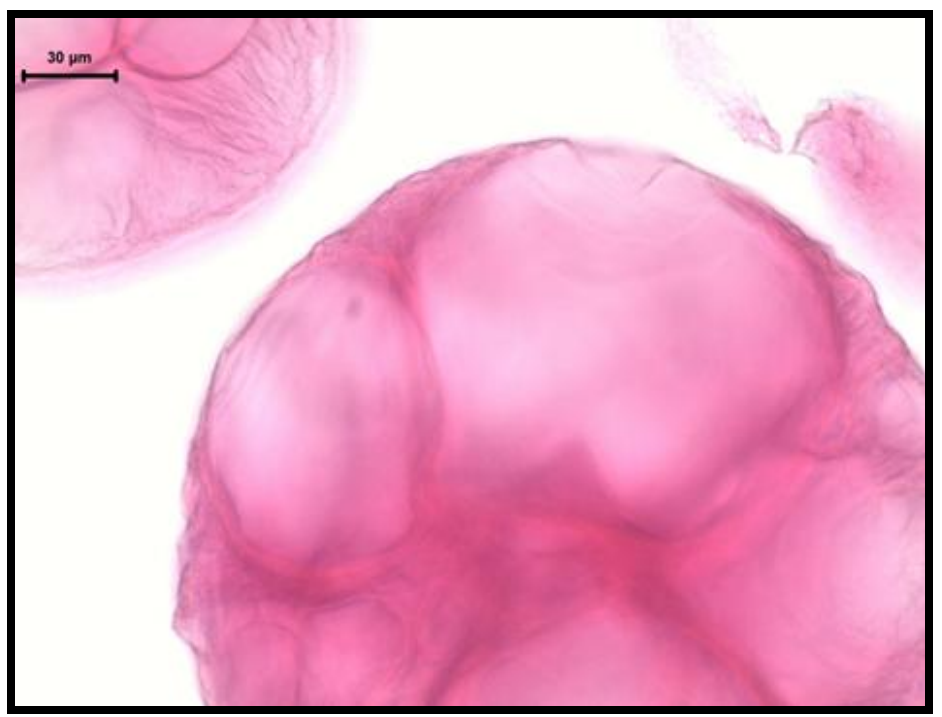

Figura 26. MO superficial da fibroína reticulada (aumento de 100x).

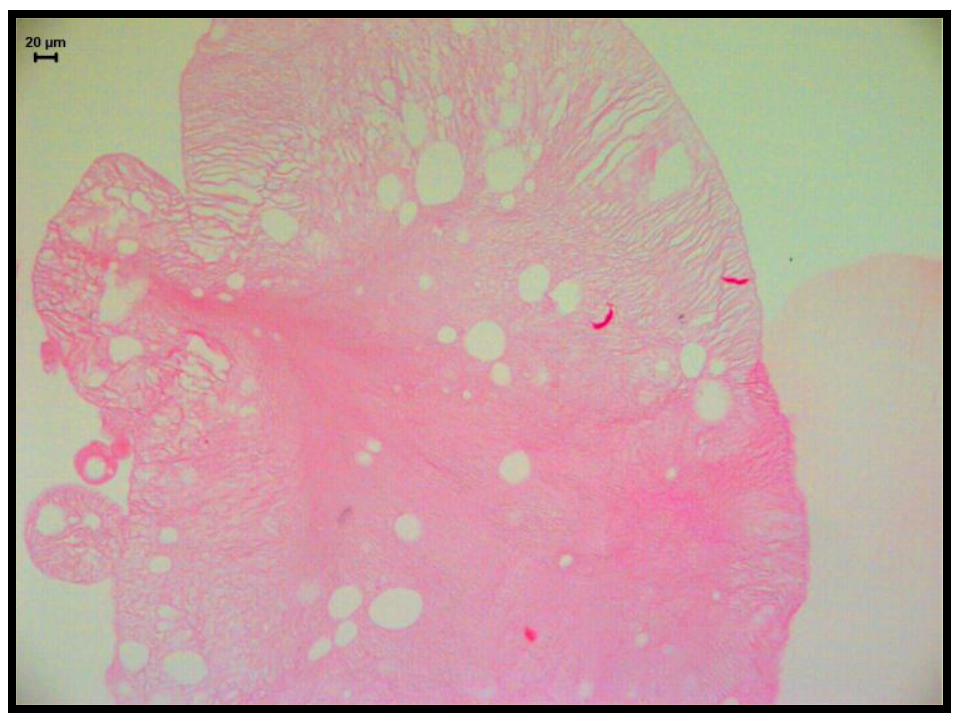

Figura 27. MO do corte das micropartículas da fibroína não reticulada (aumento de 100x). 


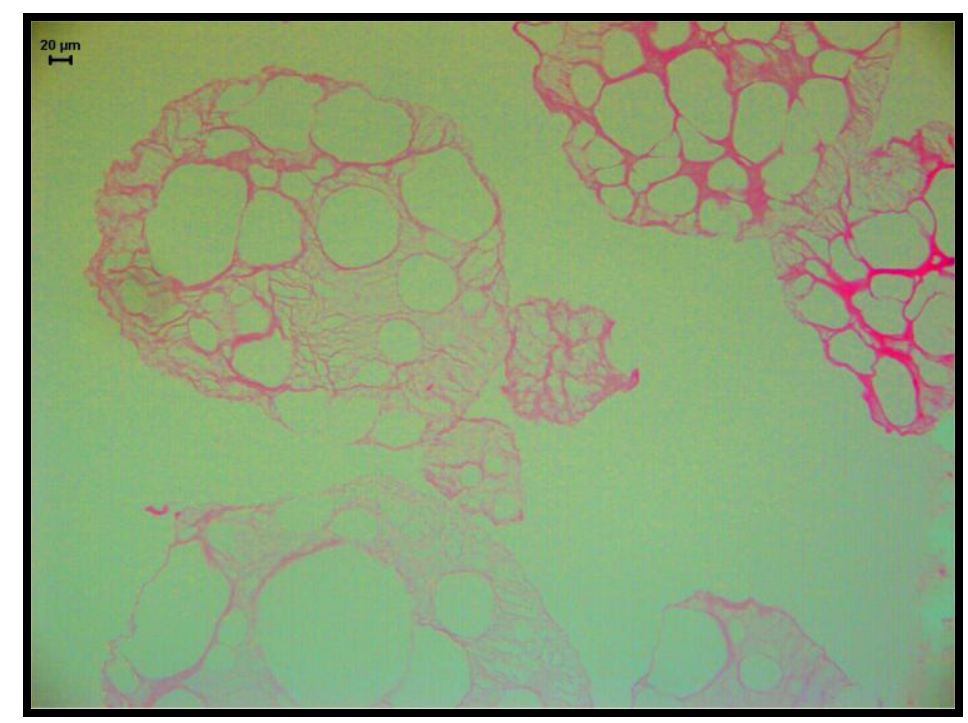

Figura 28. MO do corte das micropartículas da fibroína reticulada (aumento de 100x).

A estrutura interna das micropartículas pode-se formar pela separação de fase de uma solução polimérica. Segundo Kim et al. 2007 quando a temperatura do ponto de congelamento da solução é mais baixa que a do solvente, a cristalização do solvente ocorre primeiro e expulsa o polímero do local, formando agregação polimérica.

\section{4 - Microscopia Ótica de Birrefringência}

$\mathrm{Na}$ análise feita por microscopia ótica de birrefringência, (Fig. 30) mostra as micropartículas do colágeno reticulado, nota-se que há uma alta concentração, orientação, estado de agregação e deposição de fibras de colágeno, quando comparado ao colágeno não reticulado (Fig. 29), existem também áreas desorganizadas nas quais as fibras perdem a sua continuidade e, consequentemente, há estrutura "inchada" ou swollen indicando que houve alterações significativas estruturais na proteína colágena. 
O mesmo acontece com as micropartículas de fibroína reticulado (Fig. 32) e não reticulado (Fig. 31), porém quando comparados com as de colágeno observa-se um aumento na quantidade de poros ou bolhas.

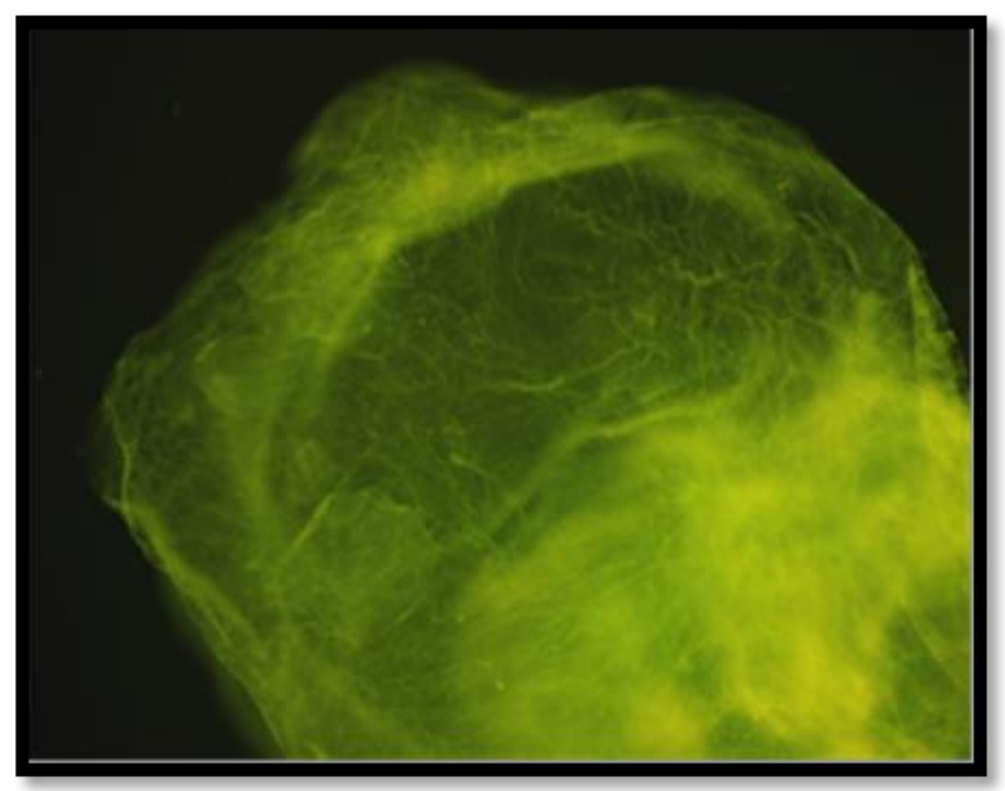

Figura 29. Birrefringência do colágeno não reticulado (aumento de 10x).

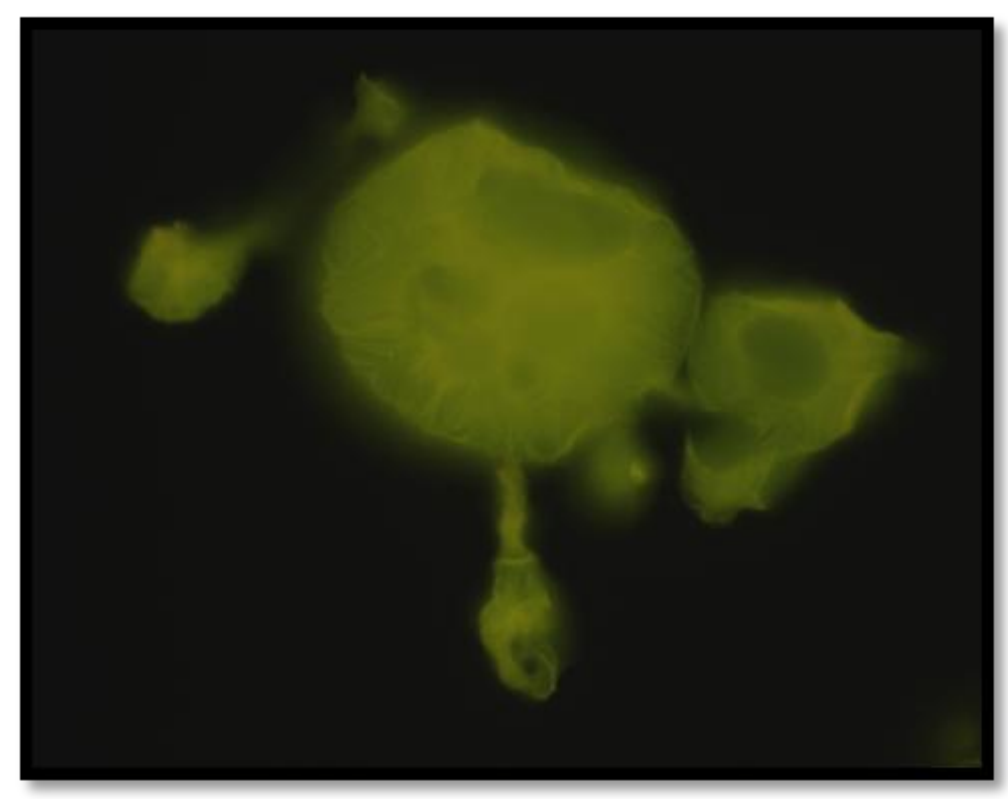

Figura 30. Birrefringência do colágeno reticulado (aumento de 10x). 


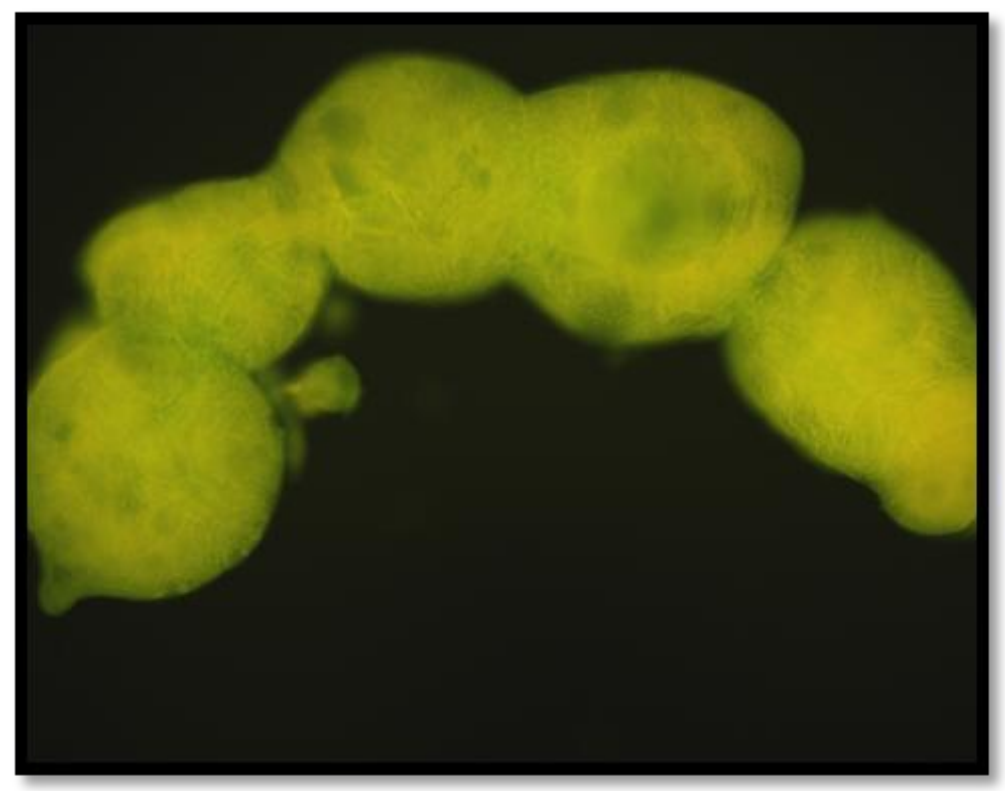

Figura 31. Birrefringência de fibroína não reticulada (aumento de 10x).

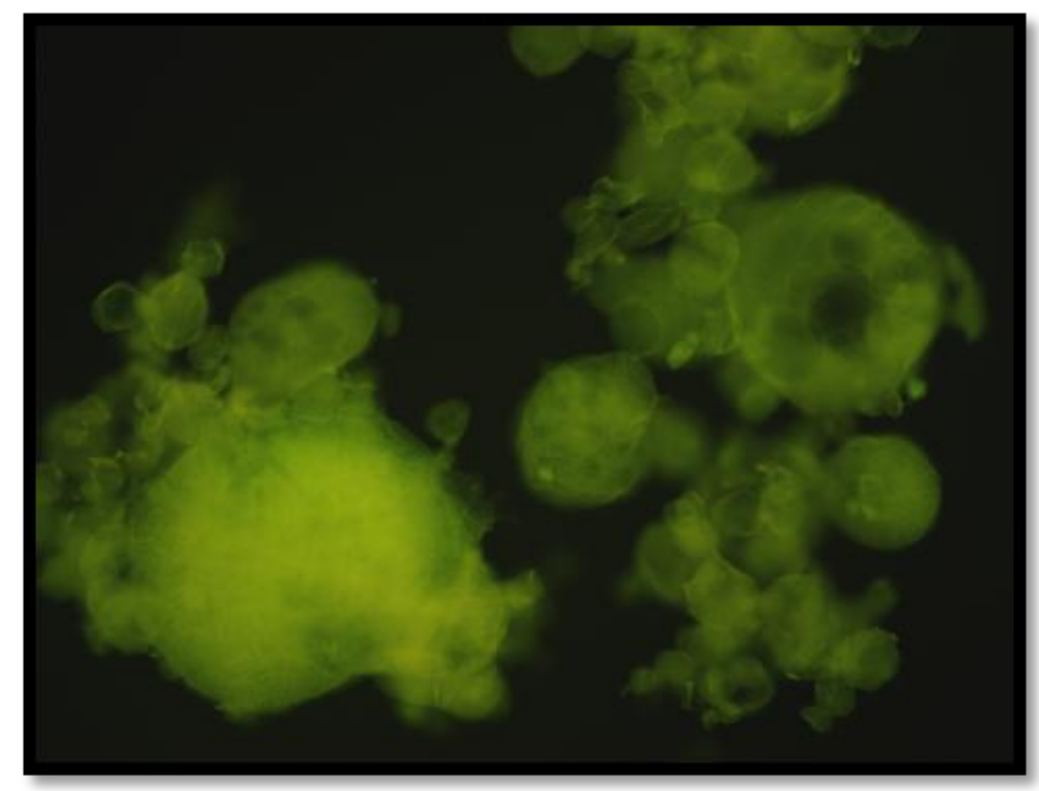

Figura 32. Birrefringência de Fibroína reticulada (aumento de 10x). 


\section{5 - Espectroscopia no infravermelho}

As regiões de amida I, II e III presentes no espectro de IV estão relacionadas com a conformação das cadeias peptídicas do colágeno. A amida I tem freqüência característica na faixa de 1656 a $1602 \mathrm{~cm}^{-1}$ associada à deformação axial da ligação $\mathrm{C}=\mathrm{O}$, conforme observada na Fig. 33. Já a amida II, que está relacionada à deformação angular N-H e ao estiramento C-N, encontra-se na faixa de 1547 e $1542 \mathrm{~cm}^{-1}$ para as micropartículas não reticuladas. Enquanto a banda de amida III esta relacionada aos modos de estiramento $\mathrm{C}-\mathrm{N}$ e deformação $\mathrm{N}-\mathrm{H}$ em aproximadamente $1450 \mathrm{~cm}^{-1}$ (PLEPIS; GOISSIS, DAS_GUPTA, 1996).

A análise do espectro de absorção no infravermelho mostrou que a razão de absorbância em $1235 \mathrm{~cm}^{-1}$ e $1450 \mathrm{~cm}^{-1}$, está proxima de 1 , portanto mantendo a estrutura helicoidal íntegra, isto implica em colágeno com baixo teor de gelatina, pois micropartículas de gelatina nas mesmas condições apresentam uma relação de 0,59 (GEORGE, 1991).

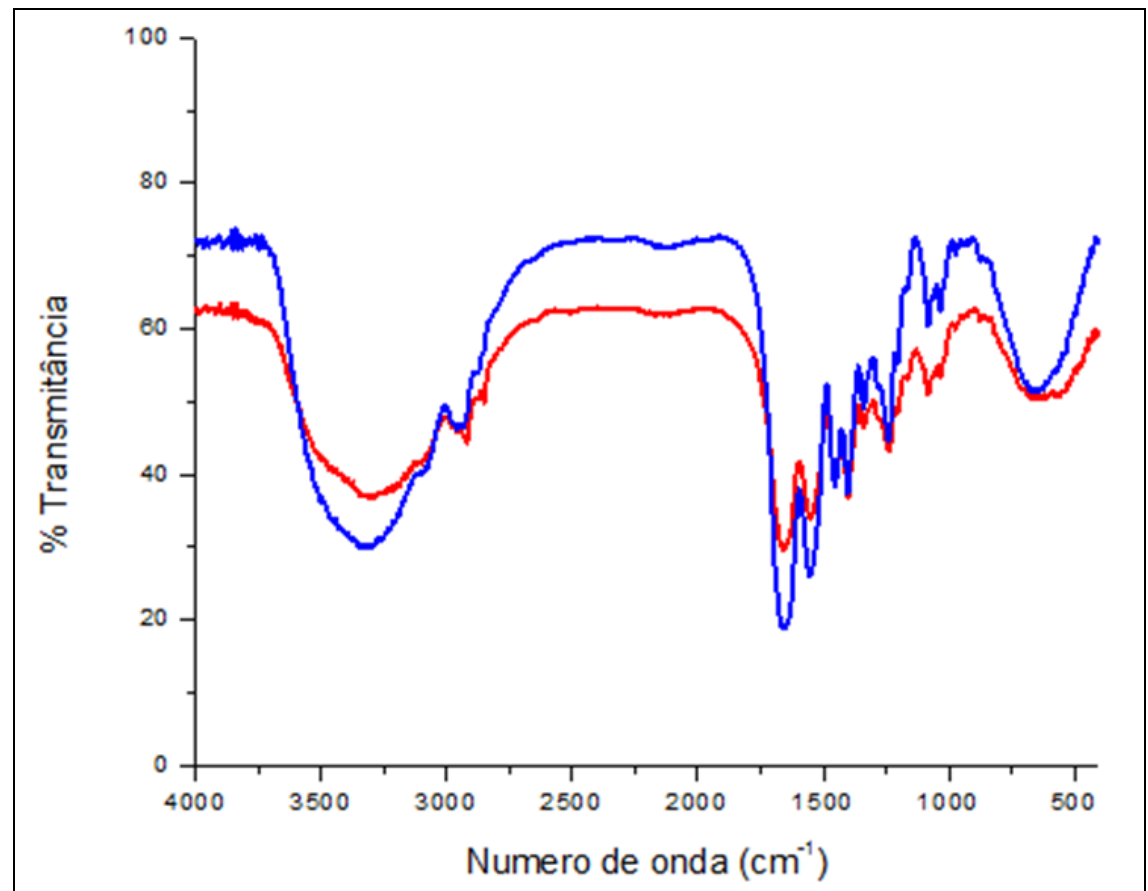

Figura 33. Espectroscopia de Infravermelho Colágeno: (——-)Não Reticulado (一-) Reticulado

Para a fibroína (Fig. 34), as bandas de amida I, II e III são atribuídas ao estiramento $\mathrm{C}=\mathrm{O}$, deformação $\mathrm{N}-\mathrm{H}$, e dobramento $\mathrm{O}-\mathrm{C}-\mathrm{N}$, respectivamente. Duas 
bandas distintas têm sido associadas com as vibrações da amida I, aparecendo em 1668 e $1577 \mathrm{~cm}^{-1}$ como contribuições das conformações seda I (enovelamento aleatório e estrutura $\alpha$ hélice) e seda II (estrutura folha- $\beta$ ), respectivamente. Na região da amida II, onde o pico em $1539 \mathrm{~cm}^{-1}$, devido à conformação seda I, é desviado para $1463 \mathrm{~cm}^{-1}$ quando ocorre transição para a conformação seda II. Já a banda da amida III ocorre na faixa de 1242 a $1157 \mathrm{~cm}^{-1}$. A banda em $1242 \mathrm{~cm}^{-1}$ se deve à conformação seda I, enquanto que a banda em $1157 \mathrm{~cm}^{-1}$ é atribuída à fase cristalina (seda II) (RUSA et al., 2005).

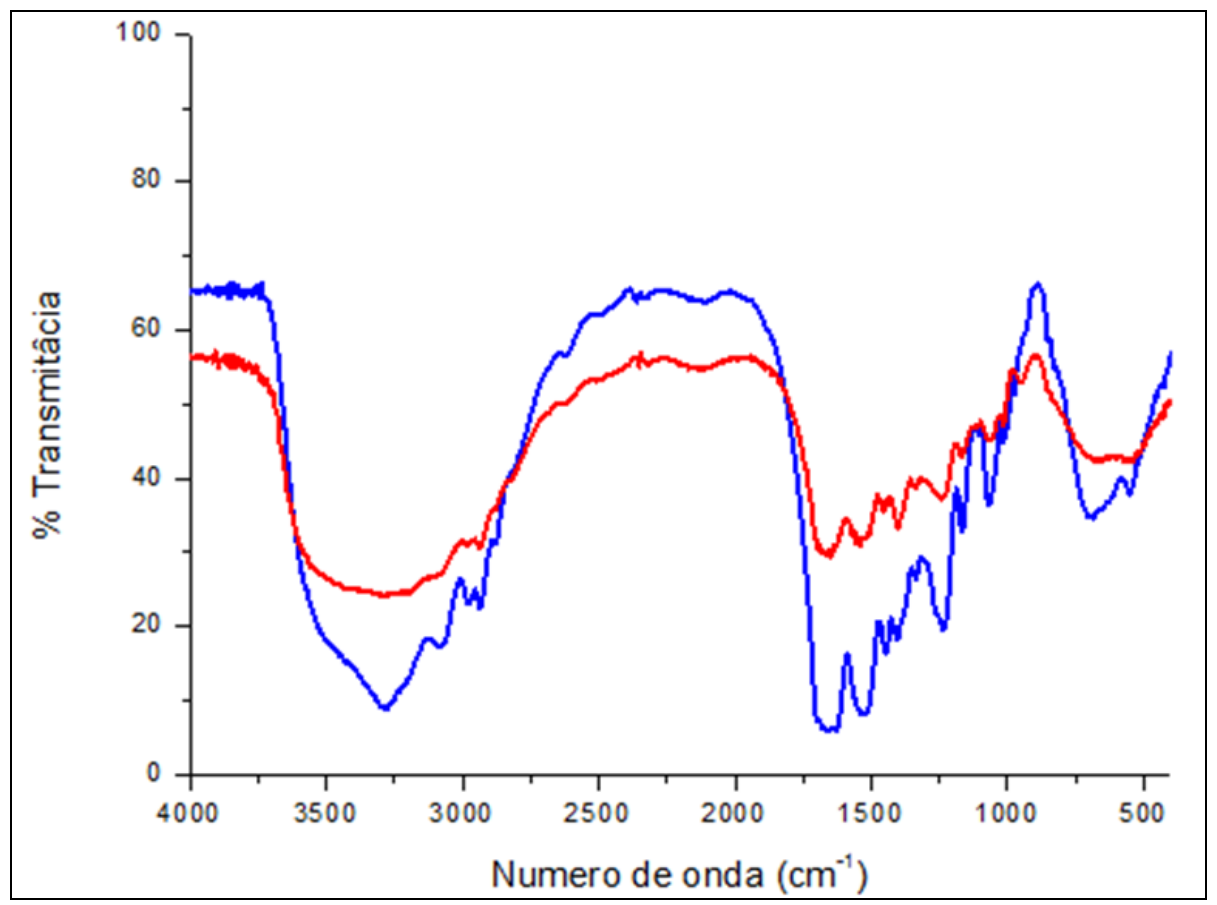

Figura 34. Espectroscopia de Infravermelho Fibroína: (——-)Não Reticulada (一-) Reticulada.

O tratamento com glutaraldeído induziu o aumento da proporção da conformação seda II (UM et al., 2004; ZUO et al., 2007; LAWRENCE et al., 2008) apresentando uma proporção maior de estrutura cristalina folha- $\beta$, e menor de enovelamentos aleatórios e hélice- $\alpha$, quando comparadas com as micropartículas não reticuladas (LV et al., 2005; MIYAGUCHI; HU, 2005; RUSA et al., 2005).

Através da caracterização por DSC, MEV, MO e birrefringencia das micropartículas de colágeno e de fibroína, pode-se observar a temperatura de desnaturação e decomposição e a extensão da superfície do material, observando que quando estas são tratadas com reticulante GA, favorece o aumento da rugosidade, formação de poros, aumento na temperatura de desnaturação do colágeno e decomposição da fibroína, assim como a definição e orientação das fibras, pois o GA 
reage com o e-amino de lisina (Lys) e hidroxilisina (Hyl) da matriz protéica para formar ligações químicas do tipo base de Schiff (-CH=N-) (GOISSIS ET AL, 1999).

\section{6 - Percentagens de Absorção de Água}

A absorção de água é um dado útil, pois, como relatado anteriormente, estruturas com alta porosidade interconectada facilitam a proliferação celular dentro do material e também ajudam no transporte de nutrientes (HE, STANDARD and HUANG 2008). A análise de absorção foi realizada através da equação 1, que usou o peso das micropartículas secas $(10 \mathrm{mg})$ e hidratadas.

Os resultados da porcentagem de água absorvida estão representados na Figura 35, para as micropartículas de colágeno e colágeno reticulado, e na Figura 36 para as micropartículas de fibroína e fibroína reticulada.

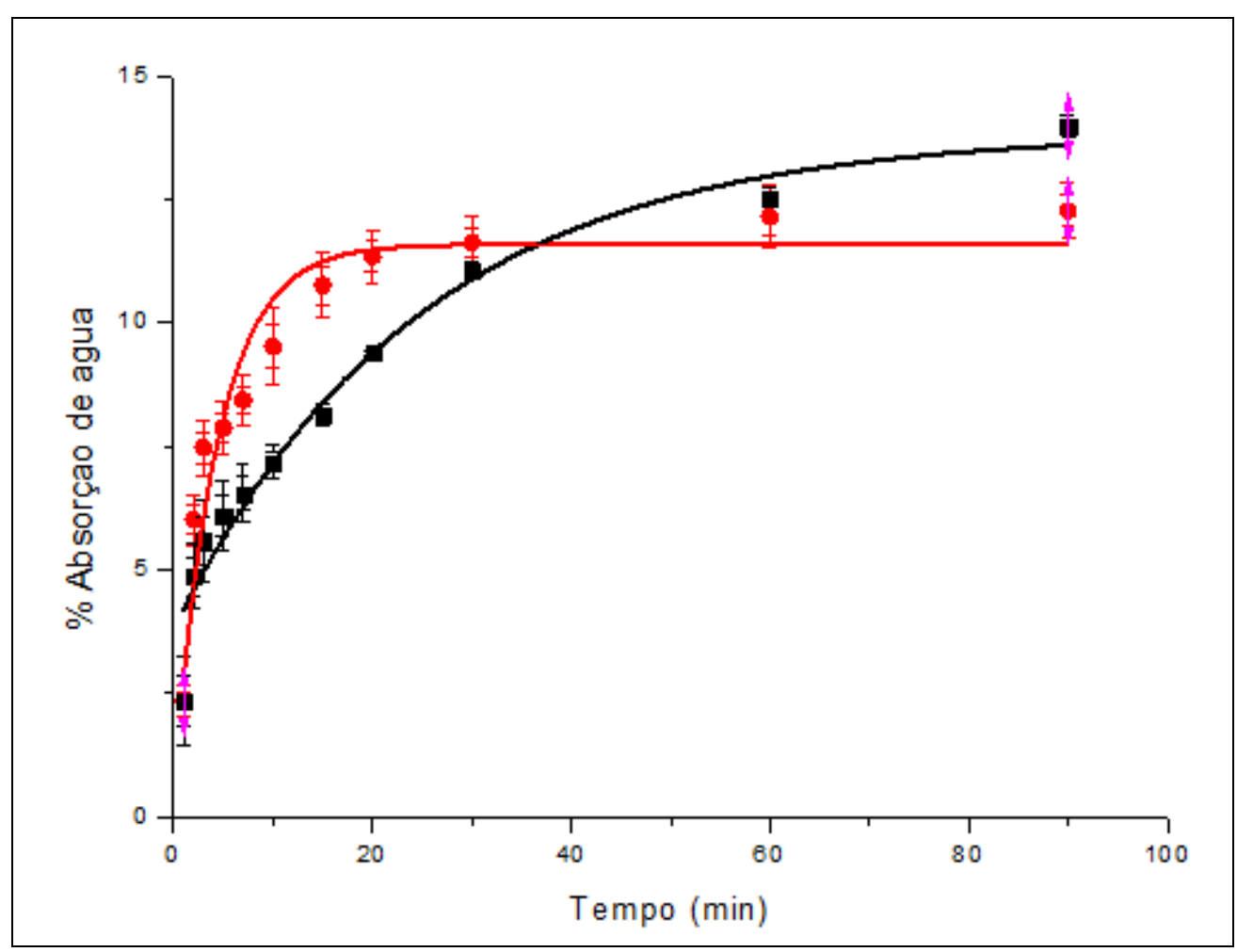

Figura 35. Porcentagem de Absorção de Água pelas micropartículas de colágeno (一-) Não Reticulado (-—) Reticulado com GA. 
Observando a Figura 35, nota-se que as micropartículas de colágeno reticulado absorvem uma quantidade maior de àgua em um período menor de tempo, se estabilizando mais rápido, isto é possível porque quando o colágeno é reticulado há o rompimento das ligações cruzadas, que aumenta o número de cargas negativas na matriz de colágeno e desorganiza a estrutura fibrilar da matriz colagênica (BET; GOISSIS; LACERDA, 2001). Com o aumento na densidade de cargas negativas, após a reticulação, a quantidade de água absorvida pelas micropartículas reticuladas é maior em relação às não reticuladas.

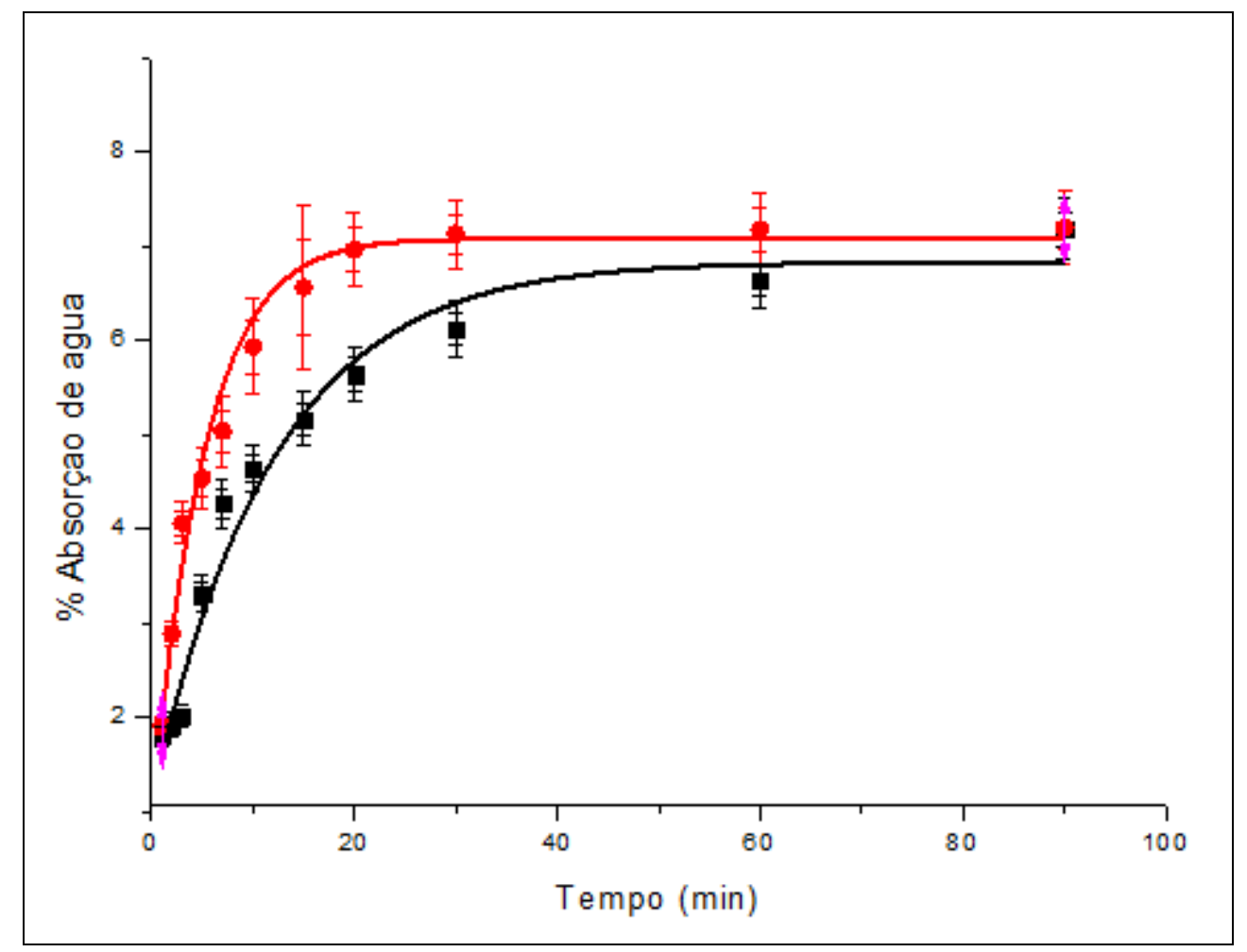

Figura 36. Porcentagem de Absorção de Água nas micropartículas de fibroína: (一-) Não Reticulada (- - ) Reticulada com GA.

As micropartículas de fibroína apresentam um grande número de resíduos hidrofóbicos, porém quando reticuladas com GA estas cadeias apresentam resíduos de hidroxila (serina e tirosina) que promovem sua afinidade com a água (HOSSAIN et. al 2003), o que justifica o resultado observado na Figura 36.

Os resultados apresentados se dão, em grande parte, a absorção de água através da superfície dos materiais, já que tanto para as micropartículas de colágeno como de fibroína observou-se que há formações de bolhas de ar no interior, e isto dificulta a entrada de água no local, mesmo assim, as micropartículas de colágeno apresentam uma 
maior capacidade de absorção de água, aproximadamente $50 \%$ mais que as micropartículas de fibroína.

Com relação às amostras tratadas com GA para ambos os compostos, colágeno e fibroína, a porcentagem de absorção atinge seu grau máximo em menor tempo, permanecendo estável, esse dado pode estar relacionado à estrutura hidrofílica do GA que, em contato com a molécula de água, ajuda na retenção.

Apesar da presença de poros, e/ou bolhas de ar, ser maior nas micropartículas de fibroína, como já visto em microscopia ótica, nas micropartículas tratadas com GA, não nota-se diferença significativa na porcentagem de absorção de água e isso pode ser explicado quando examinada a estrutura primária da cadeia pesada de fibroína, que apresenta um padrão de blocos hidrofóbicos e hidrofílicos. Esse padrão sugere a possibilidade de formação de estruturas micelares em água (JIN; KAPLAN, 2003).

Esse modelo de montagem da seda sugere que as moléculas de fibroína atuam como polímeros hidrofílico-hidrofóbico-hidrofílico, com a formação de micelas de tamanhos irregulares, dependendo do dobramento das cadeias e interações hidrofóbicas (JIN; KAPLAN, 2003), o que também justifica a formação de bolhas/poros no interior das microparticulas.

O colágeno e a fibroína são pouco solúveis em água devido a teores elevados de cadeias hidrofóbicas, esses resultados corroboram com Hardy et al 2010 e Wenk et al 2011.

\section{7 - Citotoxicidade}

O teste de citotoxicidade foi realizado para avaliação biológica do material, pois é possível que, durante a preparação, possam ocorrer modificações químicas e estruturais, que possam gerar um produto final com novos níveis de toxicidade (WENK et al 2011, BHARDWAI et al. 2011)

A análise toxicológica feita in vitro a partir do teste de MTT (Fig.37) foi observada por microscopia ótica, pela qual se verificou-se a coloração das células viáveis através da formação dos cristais de formazam no interior das células (roxas). Os cristais foram então solubilizados e o sobrenadante analisado por espectrofotometria no 
UV. Os valores numéricos obtidos pela absorbância foram submetidos à análise estatística de ANOVA que mostrou diferentes resultados a partir da cultura controle e do microcarregador Cultispher S.

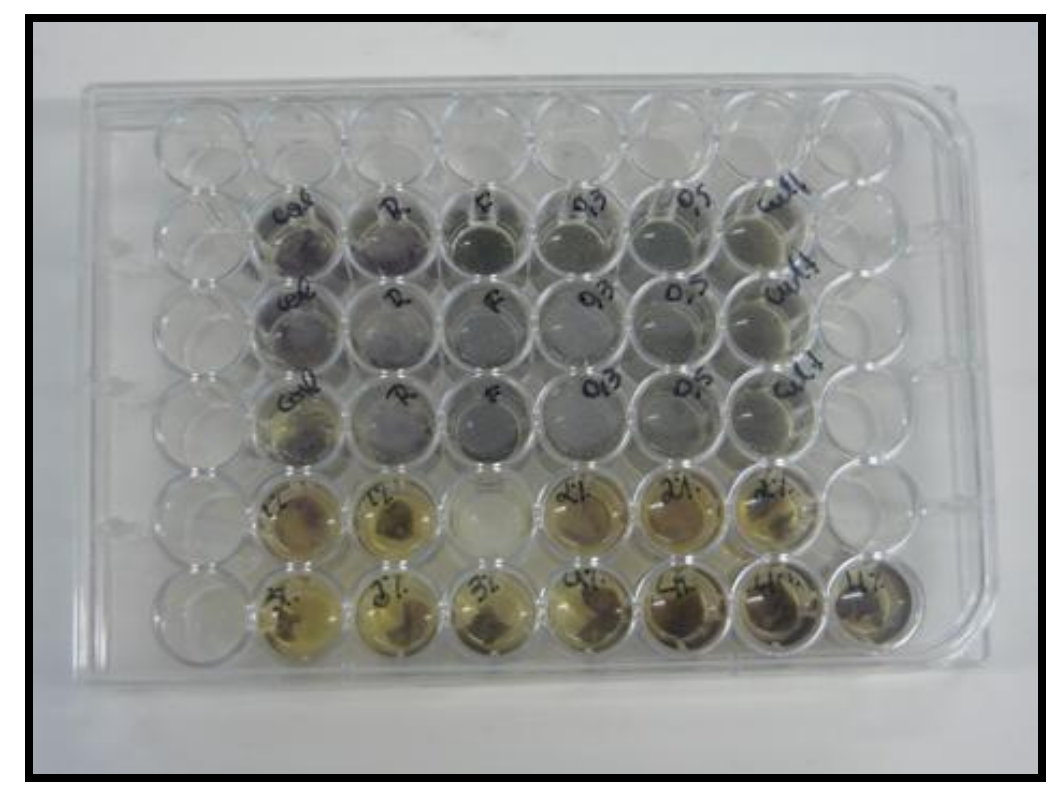

Figura 37. Microplaca com meio de cultura celular e amostras

Com o intuito de verificar se as micropartículas estavam afetando a viabilidade celular, usou-se a técnica colorimétrica com MTT, quantificando as células viáveis por espectrofotometria. Para a determinação da curva padrão do método do MTT utilizou a Equação da Reta (2):

$$
y=a+b^{*} x
$$

Encontrando assim a densidade celular de maneira indireta, substituindo o valor da absorbância (eixo x) obtidas das amostras do cultivo das CTMs nos biomateriais, Figura 38. 


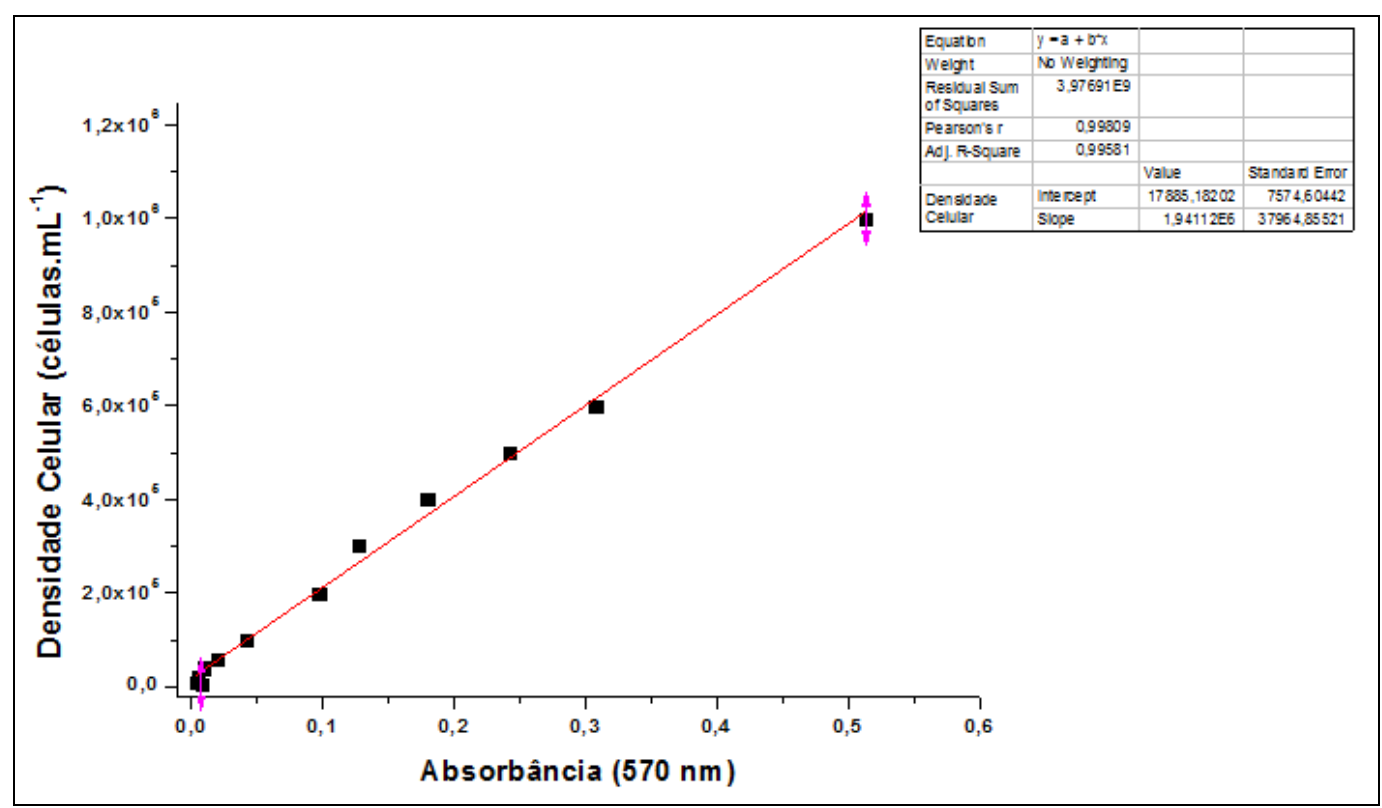

Figura 38. Curva padrão do método do MTT. Equação da reta $y=a+b x$, com coeficiente de correlação de 0,99581 . As barras correspondem ao desvio padrão das medidas.

A viabilidade e proliferação celular em função do tempo, em um suporte, são indicadores de biocompatibilidade do material (RESENDE, 2010). Em todos os cultivos houve crescimento celular após o período de $72 \mathrm{~h}$, que teve como base o valor do inóculo $\left(1 \times 10^{5}\right.$ células. $\left.\mathrm{mL}^{-1}\right)$ conforme verificado na Tabela 1 . Desta maneira, podemos afirmar de antemão que todos os biomateriais testados servem como suporte para as CTMs, mas algumas alterações ou ajustes podem ser estudados para melhorar a eficácia das micropartículas.

Tabela 1. Teste de MTT nas amostras, avaliando a densidade celular após $72 \mathrm{~h}$ de cultivo. Inóculo $=1 \times 10^{5}$ células. $\mathrm{mL}^{-1}$.

\begin{tabular}{|l|c|c|}
\hline \multicolumn{1}{|c|}{ Amostras } & $\begin{array}{c}\text { Concentração de } \\
\text { Céls. Inicial } \\
\left(\text { céls.mL }{ }^{-1}\right)\end{array}$ & $\begin{array}{c}\text { Concentração de } \\
\text { Céls. Após 72h } \\
\left(\text { céls.mL } \mathbf{H}^{-1}\right)\end{array}$ \\
\hline Controle & $1 \times 10^{5}$ & $4,02 \times 10^{5}$ \\
\hline Cultispher & $1 \times 10^{5}$ & $7,40 \times 10^{5}$ \\
\hline Micropartículas de Colágeno & $1 \times 10^{5}$ & $4,06 \times 10^{5}$ \\
\hline Micropartículas de Colágeno Reticulado & $1 \times 10^{5}$ & $4,19 \times 10^{5}$ \\
\hline Micropartículas de Fibroína & $1 \times 10^{5}$ & $3,40 \times 10^{5}$ \\
\hline Micropartículas de Fibroína Reticulada & $1 \times 10^{5}$ & $1,90 \times 10^{5}$ \\
\hline
\end{tabular}

Nos testes citotóxicos realizados, pode-se observar que houve um aumento bastante expressivo do número de células quando cultivadas junto ao microcarregador Cultispher $\mathrm{S}$, no qual o crescimento celular foi praticamente o dobro em relação ao grupo controle (Fig.41). Esse aumento expressivo no crescimento celular se dá pela 
maior área de adesão e expansão oferecida às células e outros fatores que podem influenciar como a dureza do material, o pH, o ângulo de contato, o formato esférico das partículas usadas como suporte, fazendo com que o cultivo em Cultispher S atinja um fator de expansão de 7,41 em 72 h de cultivo. O que confirma a eficiência já demonstrada por este microcarregador na expansão de células aderentes (START, SCHNEIDER, AGATHOS, 2009)

Quando comparado ao grupo controle, o colágeno e o colágeno reticulado apresentaram um aumento de apenas $1 \%$ e 4\%, respectivamente, no número de células, o que, estatisticamente, não representa uma diferença significativa. $\mathrm{O}$ fator de expansão neste caso, como observado na Tabela1, é de 4,03, 4,07 e 4,19, respectivamente.

O mesmo não ocorre com a fibroína, em nível de porcentagem, houve uma redução de $16 \%$ para fibroína e 53\% para fibroína reticulada em relação ao controle. A diminuição da taxa proliferativa das células, entre as culturas em micropartículas de fibroína reticuladas em relação às de fibroína não reticulada, pode ser explicada pela ação do agente reticulante GA, já que é considerado tóxico quando utilizado em níveis acima de $0,05 \%$.

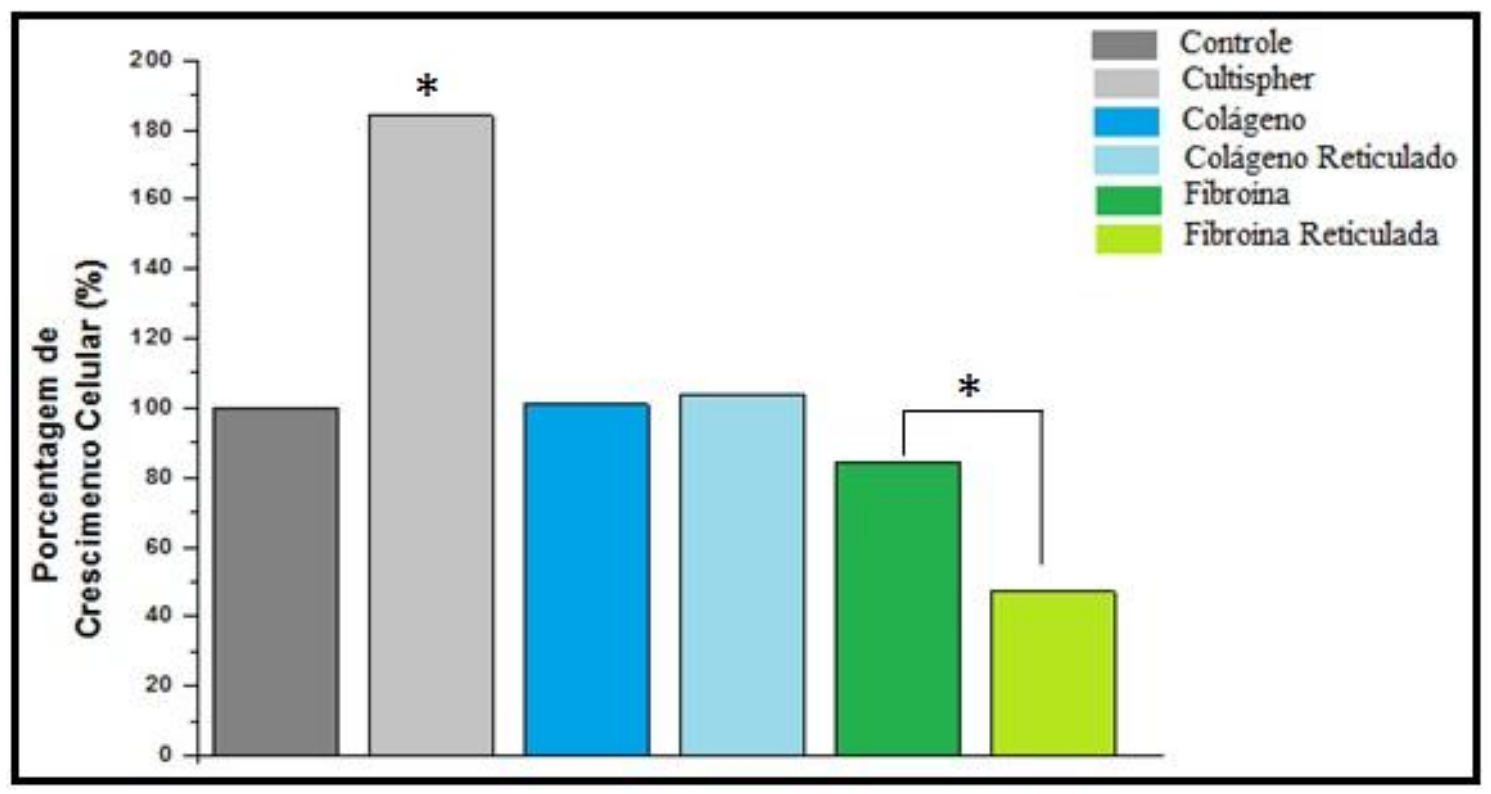

Figura 39. Porcentagem de crescimento celular nos diferentes biomateriais. O (*) indica a diferença significativa em relação ao cultivo controle ou comparando fibroína reticulada e não reticulada, com $\mathrm{P}<0,05$. 
Na Figura 40, é possível observar a imagem de microscopia ótica do grupo controle corado com MTT, observando a expansão celular após 72 h em cultivo.

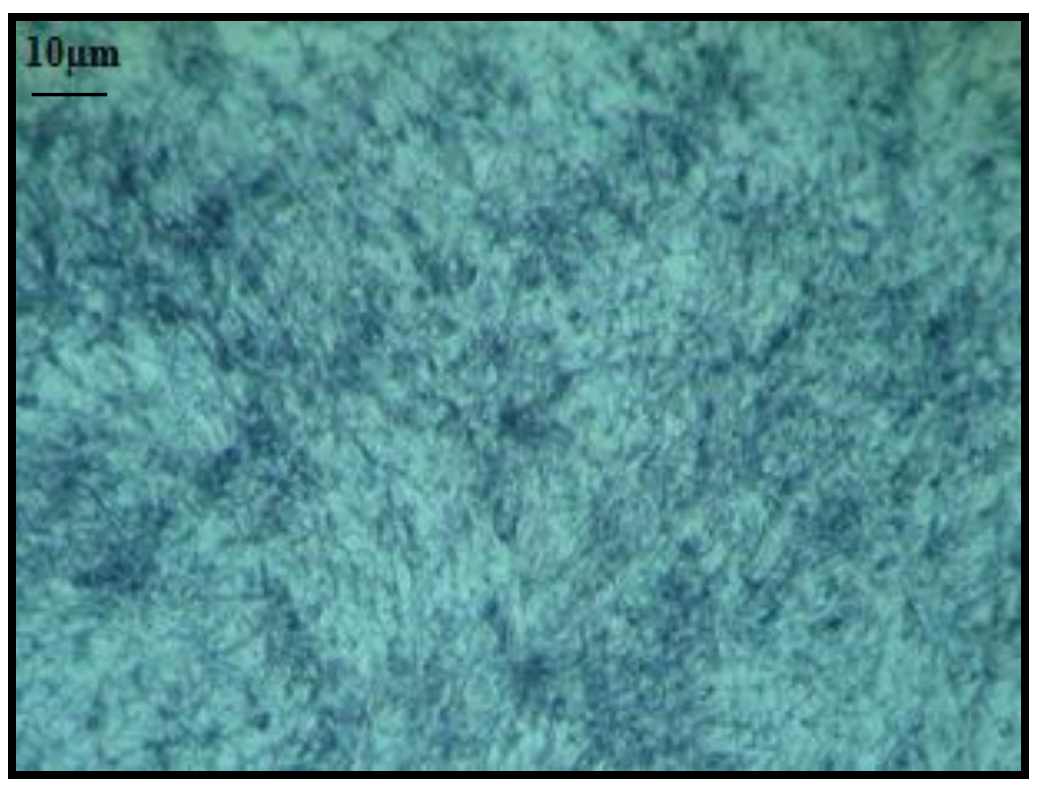

Figura 40. Microscopia ótica do meio de cultura MTT.

Nas fotomicrografias óticas com microcarregadores Cultispher S, demonstrado nas Figuras 41 e 42 (as células roxas, coradas com MTT), encontram-se distribuídas ao redor do suporte utilizado. Segundo Frauenschuh et. al (2007), a carga elétrica superficial positiva dos microcarregadores atrai fortemente as células, de forma a contribuir com o crescimento celular, mostrando ser viável e pouco tóxico. Além disso, é feito de uma matriz de colágeno reticulado o que oferece às células uma superfície apropriada, já que o colágeno é a proteína mais abundante na matriz extracelular. 


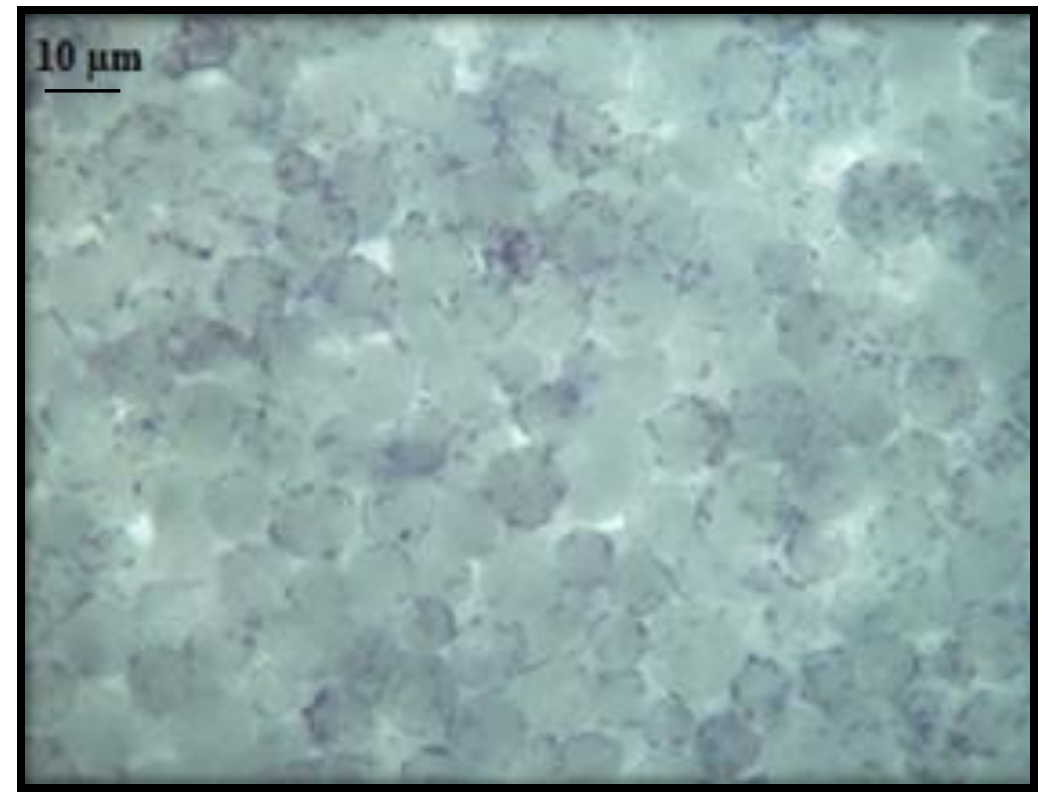

Figura 41. Microscopia ótica do meio de cultura em MTT com microcarregadores Cultispher S. Magnificação de 100x

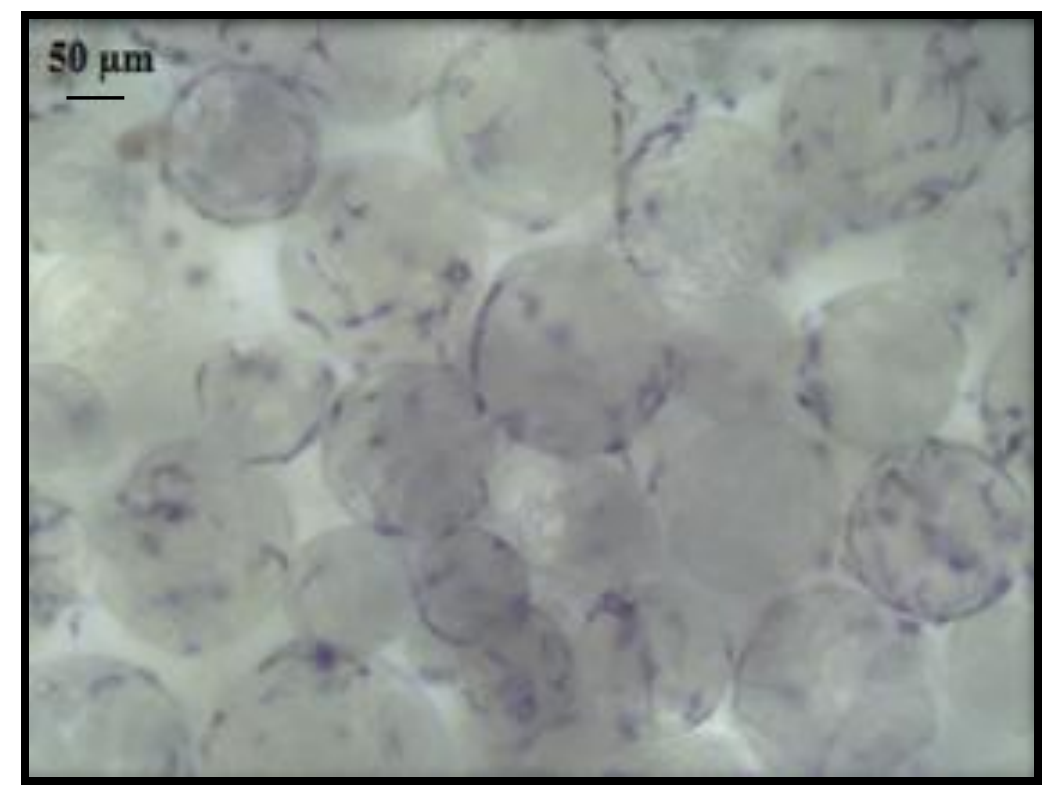

Figura 42. Microscopia ótica do meio de cultura em MTT com microcarregadores Cultispher S. Magnificação de 200x.

Ao comparar as micrografias das micropartículas de colágeno reticulado (Fig. 45 e 46) com o colágeno não reticulado (Fig. 43 e 44), pode-se observar que ambas apresentam células ao redor do material. Apresentam uma distribuição celular parecida à encontrada no Cultispher S com superposição de células ou não. 


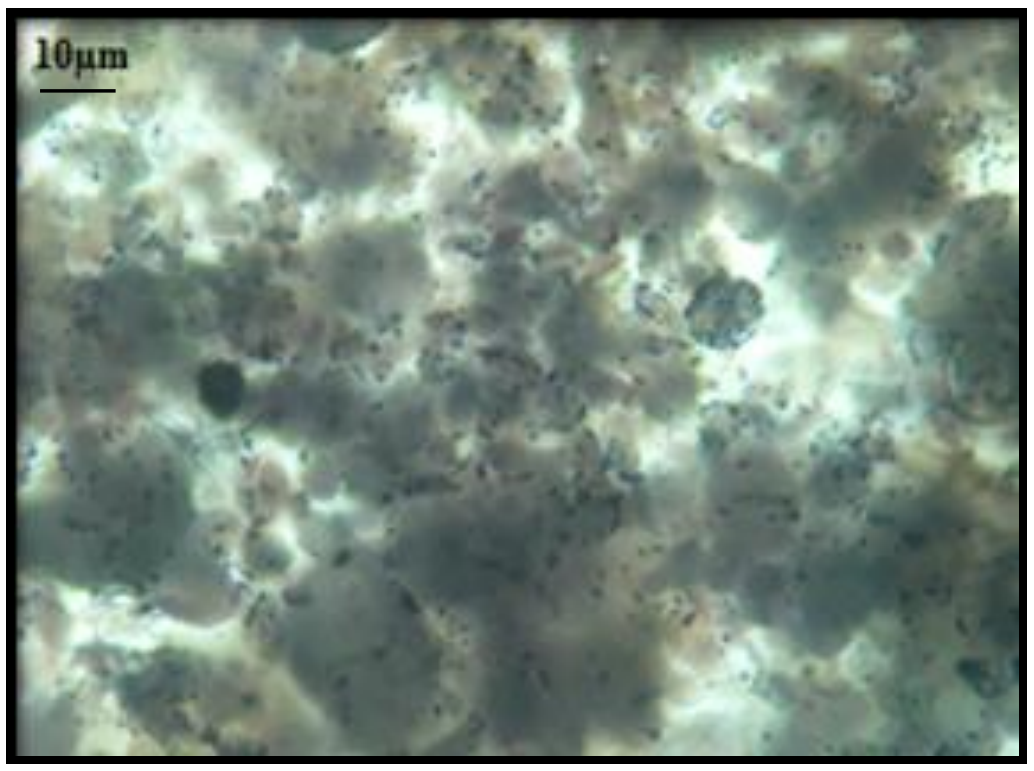

Figura 43. Microscopia ótica do meio de cultura em MTT com micropartículas de cólageno não reticulado. Magnificação de 100x.

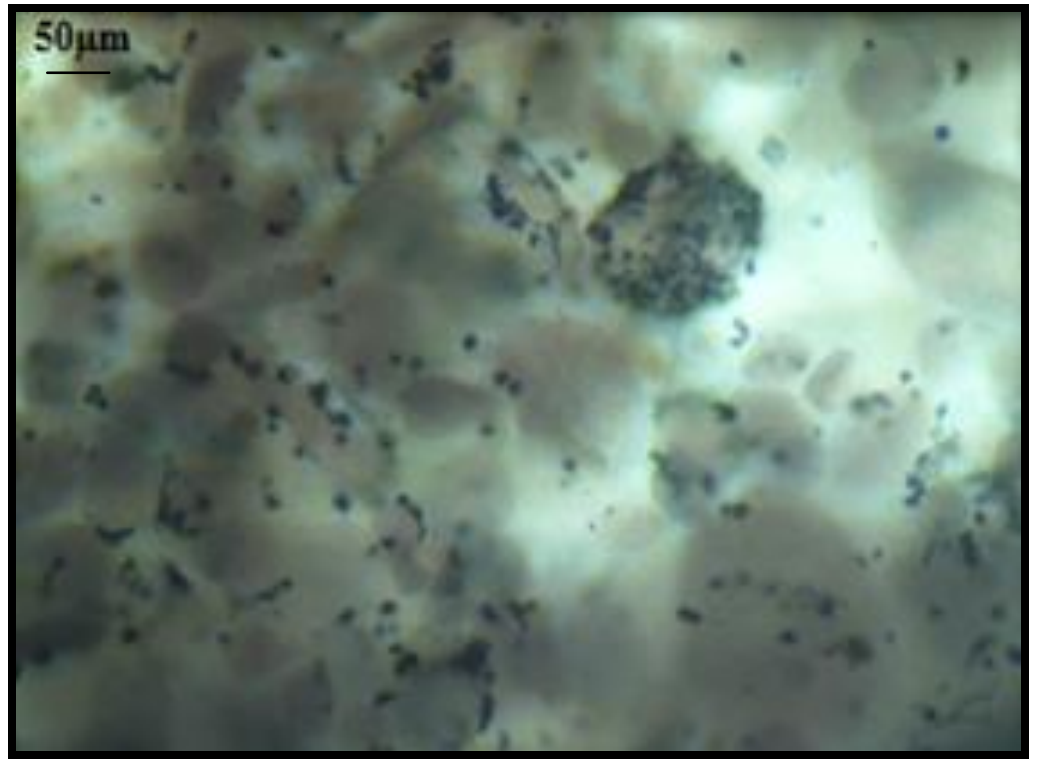

Figura 44. Microscopia ótica do meio de cultura em MTT com micropartículas de cólageno não reticulado. Magnificação de 200x. 


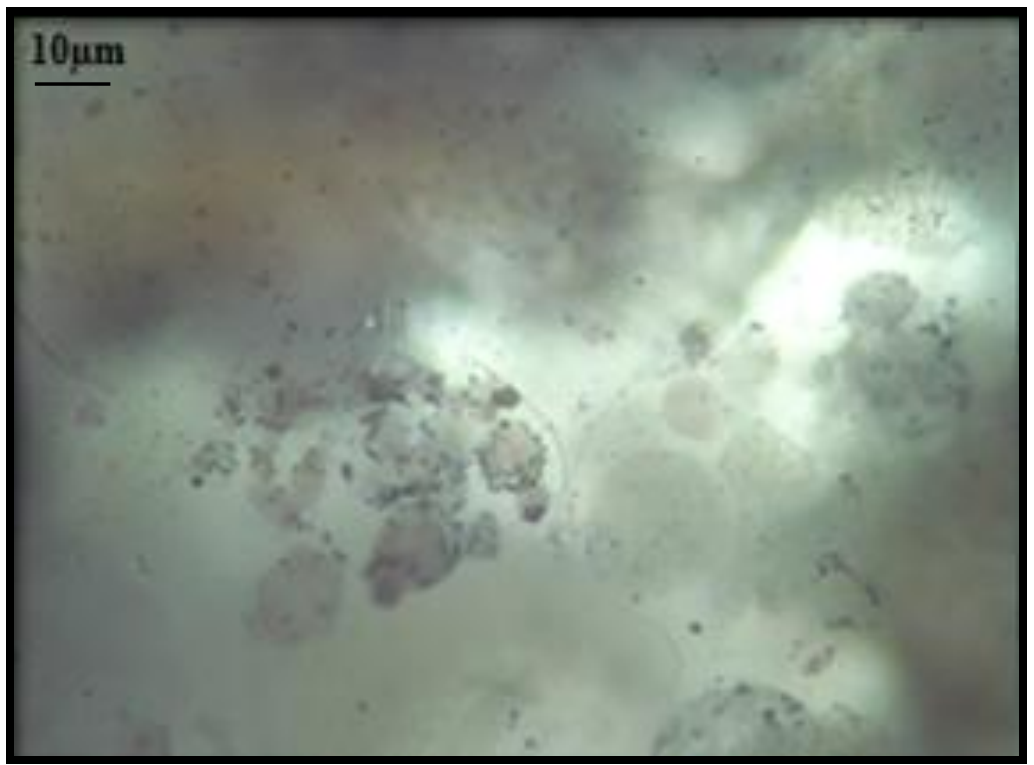

Figura 45. Microscopia ótica do meio de cultura em MTT com micropartículas de cólageno reticulado. Magnificação de 100x.

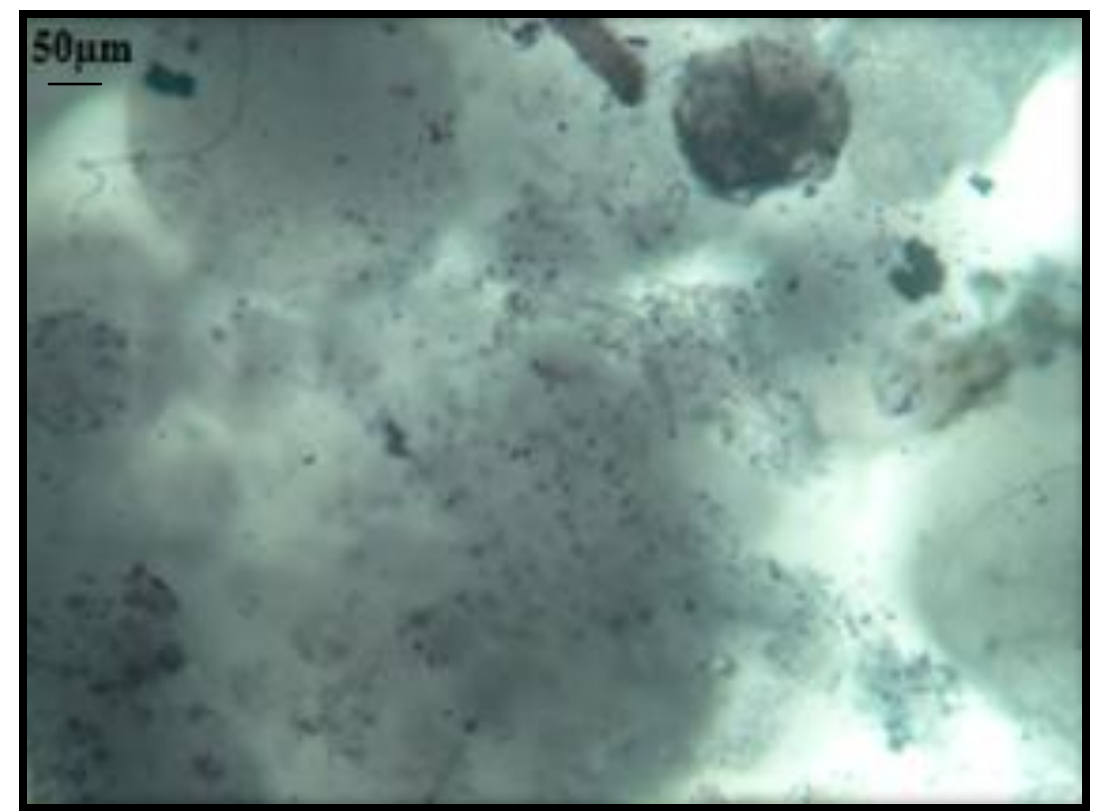

Figura 46. Microscopia ótica do meio de cultura em MTT com micropartículas de cólageno reticulado. Magnificação de 200x.

Já para a fibroína não reticulada (Fig. 47 e 48) e reticulada (Fig. 49 e 50) foi observado um crescimento celular menor quando comparados aos demais ensaios de citotoxicidade, porém não é possível afirmar que a fibroína seja tóxica às células. $\mathrm{O}$ menor crescimento celular nas micropartículas de fibroína pode ser atribuído à 
característica hidrofóbica gerada pelo material, retardando inicialmente o processo de adesão celular (VEPARI 2007, HARDY, SCHEIBEL, 2010).

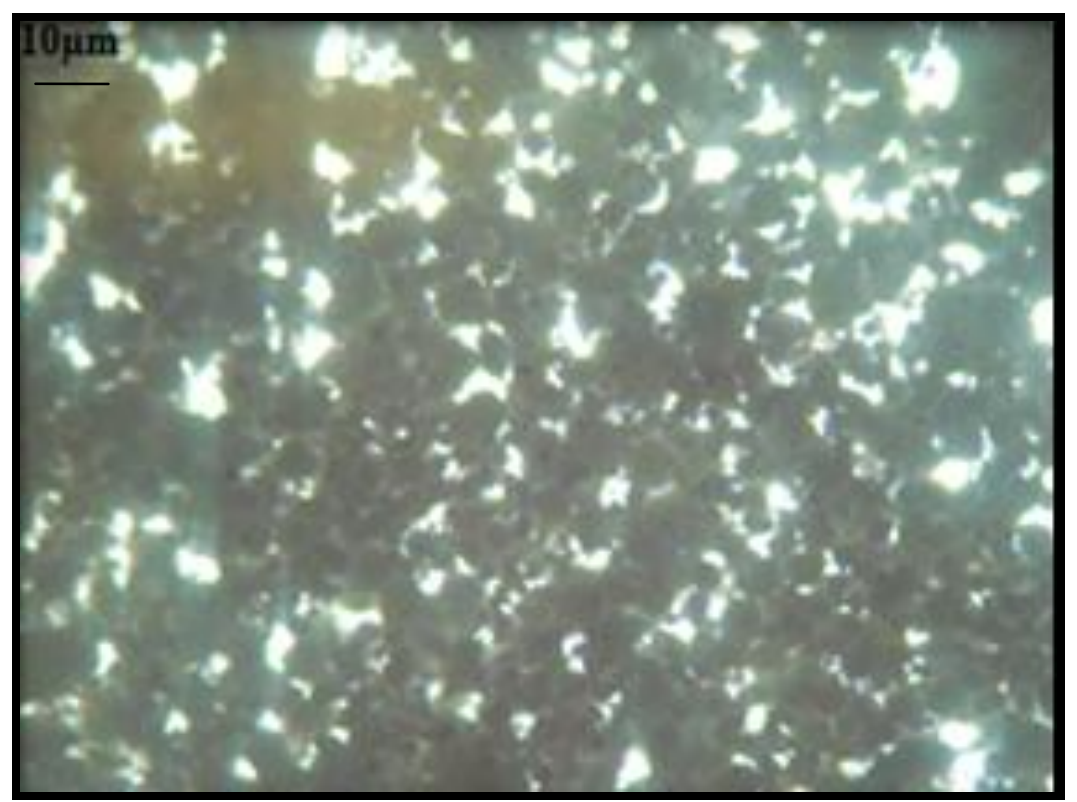

Figura 47. Microscopia ótica do meio de cultura em MTT com micropartículas de fibroína não reticulada. Magnificação de 100x.

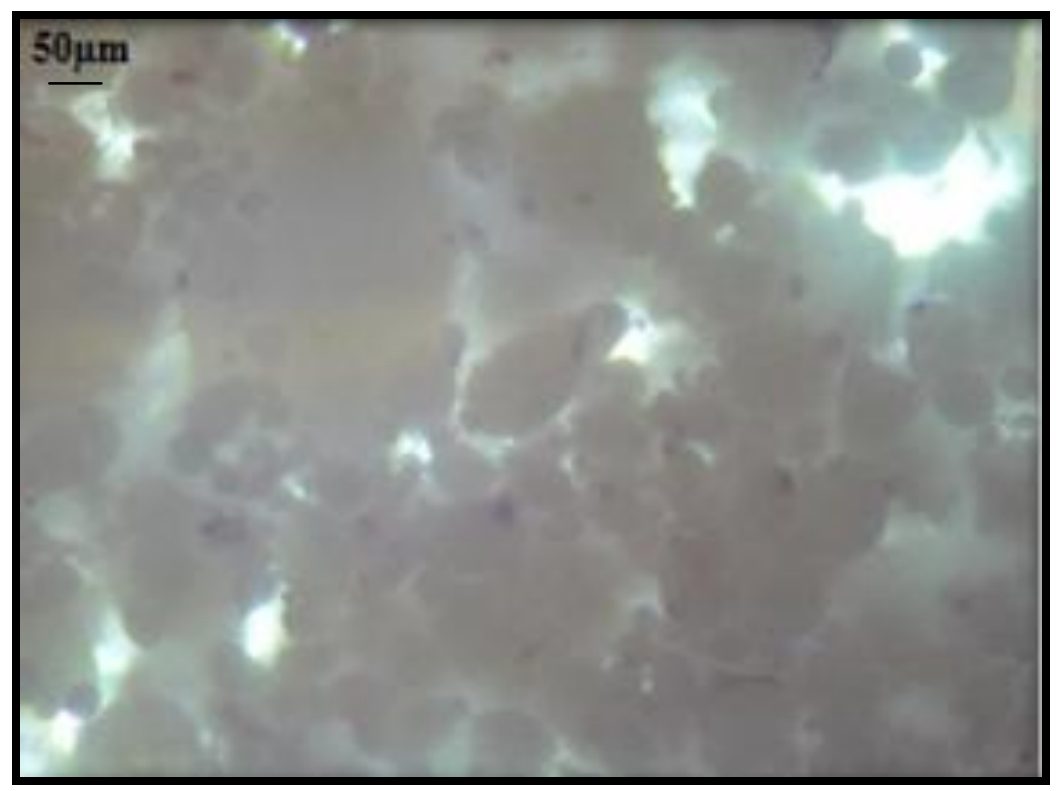

Figura 48. Microscopia ótica do meio de cultura em MTT com micropartículas de fibroína não reticulada. Magnificação de 200x. 


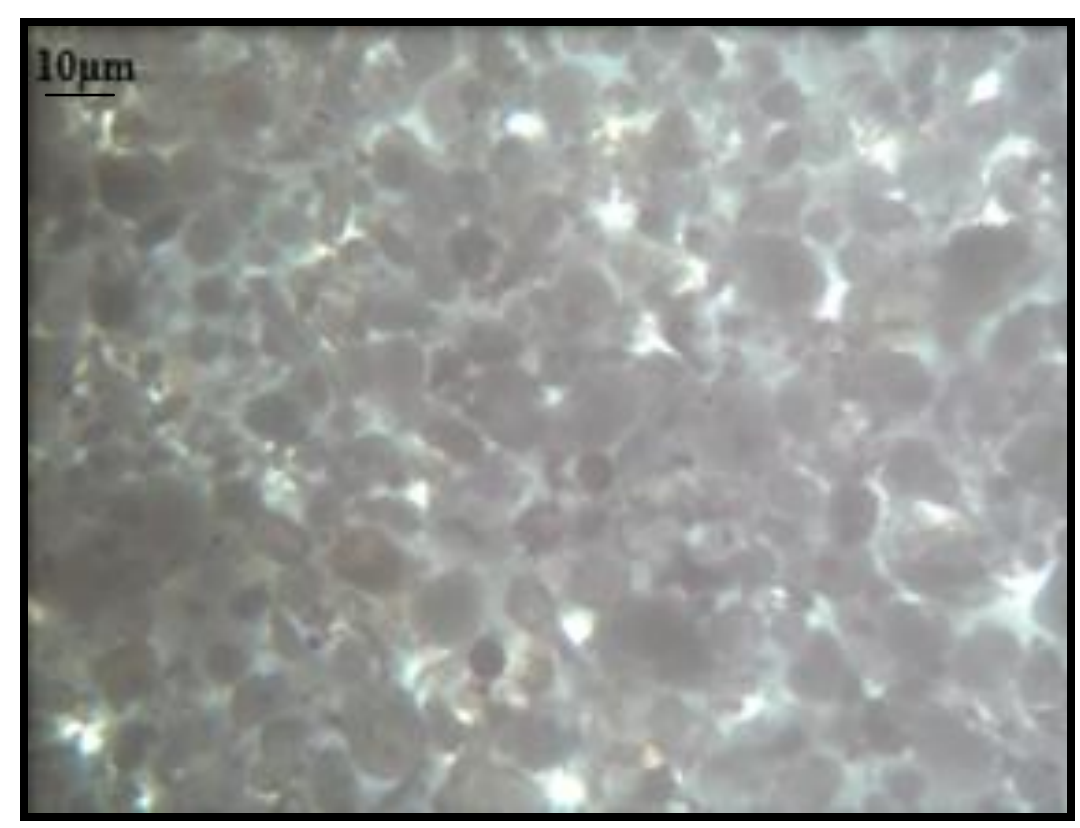

Figura 49. Microscopia ótica do meio de cultura em MTT com micropartículas de fibroína reticulada. Magnificação de 100x.

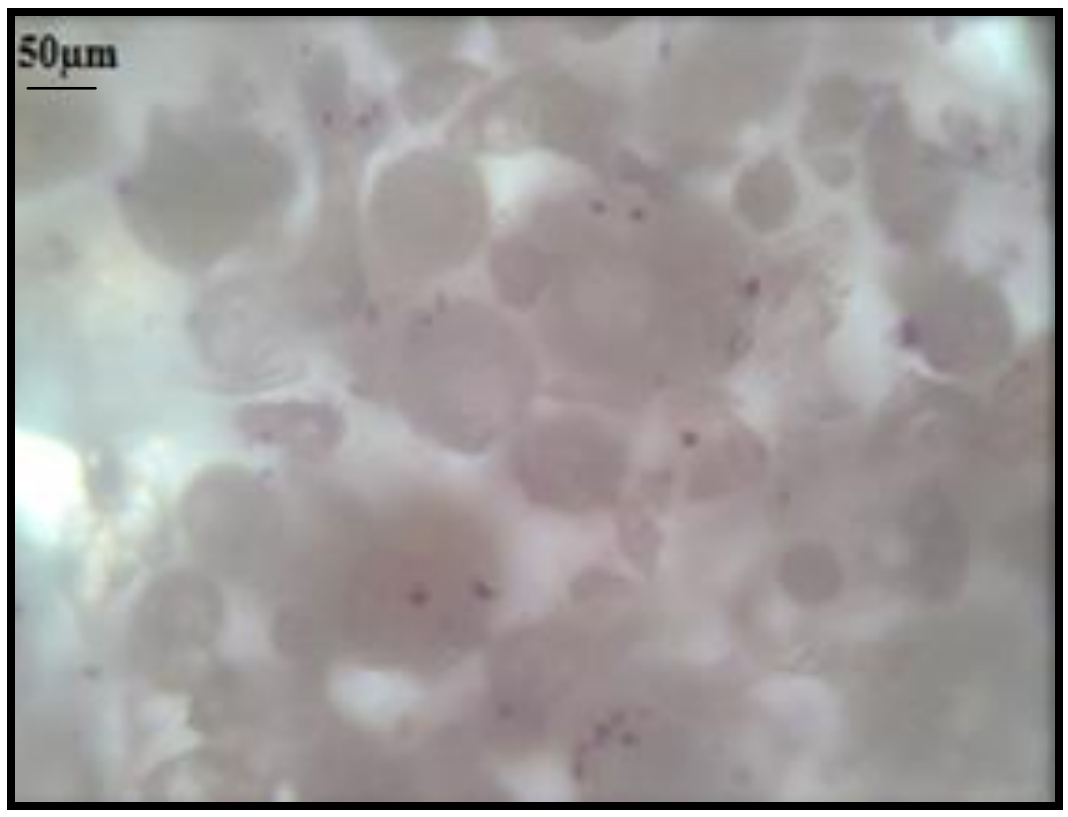

Figura 50. Microscopia ótica do meio de cultura em MTT com micropartículas de fibroína reticulada. Magnificação de 200x.

Sabe-se que o objetivo da reticulação é gerar ligações químicas cruzadas, que melhorem as propriedades mecânicas; prolongarem o tempo de degradação e que alterem as propriedades químicas, melhorando a biocompatibilidade do material (RESENDE 2010). Entretanto, os resíduos do agente reticulante podem induzir à 
redução da viabilidade celular (LIN et al 2007). Apesar disso a quantidade de células viáveis encontradas nas amostras reticuladas ou não, mostra que o material reticulado não é citotóxico. 
6. CONCLUSÃO 


\section{6 - Conclusão}

Através da metodologia empregada na preparação de micropartículas para ser usada como suportes para células-tronco observou ser eficaz e obteve materiais com estruturas porosas, principalmente quando tratadas com o glutaraldeído.

Quanto à resistência térmica, a fibroína se decompõe a uma temperatura mais elevada que o colágeno, visto que o colágeno se desnatura às temperaturas menores que $70^{\circ} \mathrm{C}$, isto sugere que as micropartículas de fibroína podem ser esterilizadas em uma autoclave comum sem perder suas propriedades químicas e biológicas.

A caracterização físico-química e biológica das micropartículas de colágeno e fibroína mostra que são consideradas pouco tóxicas in vitro, contudo, a fibroína se apresenta mais esférica e hidrofóbica como observada no teste de absorção de água, o que pode justificar a menor quantidade de células aderidas.

A presença de poros, reentrâncias e uma superfície mais rugosa encontradas nas micropartículas reticuladas, em especial na fibroína, pode possibilitar que as células possam aderir melhor e recobrir todo o suporte, porém necessita de um tempo maior para essa expansão. 
7. PERSPECTIVAS DE TRABALHOS FUTUROS 
A experiência inicial adquirida neste trabalho permite sugerir alguns estudos de aprimoramento, como por exemplo:

- Desenvolver um processo para obter tamanhos mais uniformes e esféricos.

- Microesferas de fibroína com adição de fatores de crescimento, como suportes celulares mais controlados e uso de outros tipos de células.

- Micropartículas para liberação controlada de fármacos

- Imobilização ou encapsulação de enzimas ou células para preparação de compostos bioativos ou de interesse comercial, tais como antibióticos. 
8. REFERÊNCIAS 


\section{REFERÊNCIAS $^{1}$}

ALSBERG, E.; KONG, H. J.; HIRANO, Y.; SMITH, M. K.; ALBEIRUTI, A.; MOONEY, D. J. Regulationg bone formation via controlled scaffold degradation. J. Dent. Res., v.82 (11), p.903-8, 2003.

ALTMAN, G. H.; DIAZ, F.; JAKUBA, C.; CALABRO, T.; HORAN, R. L.; CHEN, J.; LU, H.; RICHMOND, J.; KAPLAN, D. L. Silk-based biomaterials. Biomaterials, v.24, p. 401416, 2003.

AMBROSE, C. G.; CLANTON, T. O. Bioresorbable polymers in tissue engineering Ann. Biomed. Eng., v.32, p.171, 2004.

ANGELE, P. et al. Influence of different collagen species on physico-chemical properties of crosslinked collagen matrices .Biomaterials, v.25, p.2831-2841, 2009.

BEPPU, M. M. Estudo da calcificação in vitro de quitosana. 1999. Tese (Doutorado em Engenharia Química) - Faculdade de Engenharia Química, Universidade Estadual de Campinas, Campinas, 1999.

BEPPU, M. M.; SANTANA, C. C. Influence of calcification solution on in vitro chitosan mineralization. Materials Research, v. 5, n. 1, p. 47-50, 2002.

BEPPU, M. M.; POLAKIEWICZ, B.; NOGUEIRA, G.M. Study of sterilization and in vitro calcification of silk fibroin membranes for biomaterial application .INPI/Brasil, PI: 06019757, 2006.

BET, M.R.;GOISSIS, G.; LACERDA, C.A. Characterization of polyanionic collagen prepared by selective hydrolysis of asparagines e glutamine carboxyamide side chains. Biomacromolecules, v.2, p.1074-1079, 2001.

BHARDWAJ, N. et al. Potencial of 3D tissue constructs, engineered from bovine chondrocytes/silk fibroin-chitosan for in vitro cartilage tissue engineering. Biomaterials, v.32, n.25, p. 5771-5781, 2001.

BOSNAKOVKI, D. Chondrogenic Differentiation of Bovine Bone Marrow Mesenchymal Stem Cells (MSCs) in Different Hydrogels: Influence of Collagen Type II Extracellular Matrix on MSC Chondrogenesis. Biotechnology and Bioengineering, v. 93, n. 6, p. 11521163, 2006.

BOSS, J. H. et al The relativity of biocompatibility. A critique of the concept of biocompatibility. Israel Journal of Medical Sciences, v. 31, p.203-209. 1995.

BRODSKY, B.; RAMSHAW, J. A. The collagen triple-helix structure. Matrix Biol., v.15, n. 8-9, p.545-54, 1997.

${ }^{1}$ De acordo com a Associação Brasileira de Normas Técnicas. NBR6023. 
CAnevarolo, S. V. Jr. Técnicas de Caracterização de Polímeros. São Paulo: Editorial Artliber, 2004. 448 p.

CHAUDRY, Z. F. et. al. Preparation and characterization of anionic collagen by selective hydrolysis of internal carboxamide groups. Polímeros, São Carlos/SP, v.7, n.2, p. 40-46, 1997.

CUNNIFF P. M. et al. Mechanical and thermal properties of dragline silk from the spider, Nephila clavipes. Polym. Adv. Technol, v.5, p.401-10, 1995.

DEAN, Jr. et al. Weighted collagen microsponge for immobilizing bioactive material, U.S. Patent 4997753, 2003.

FEUGUIER, P. et al. Attachment, morphology and adherence of human endothelial cells to vascular prosthesis materials under the action of shear stress. Biomaterials, v.26, n.13, p.14571466, 2005.

FISCARELLI, P. E. Estudo da Hemocompatibilidade de Membranas de Colágeno Nativo e Aniônico. Dissertação (Mestrado em Química Analítica) - Universidade de São Paulo, São Carlos, 2004.

Five Year Plan: Multy-Agency Tissue Engineering Science (MATES) Work. Disponivel em:<www.tissueengineering.gov/5yearplan.htm>Acesso em: 14 de novembro de 2011.

FRAUENSCHUH, S. et al. Microcarier-based cultivation system expansion of primary mesenchymal stem cells. Biotechnol. Prog., v. 23, p.187-193, 2007.

FREDDI, G.; PESINA, G.; TSUKADA, M., Swelling and dissolution of silk fibroin (Bombyx mori) in $\mathrm{N}$-methyl morpholine N-oxide. International Journal of Biological Macromolecules, v.24, p.251-263, 1999.

FREISCHLAG, J.; MOORE, W. Clinical experience with a collagen-impregnated knitted dacron vascular graft. Ann. Vasc. Surg., v.4, p.449-454, 1994.

FUCHS, S.; MOTTA, A.; MIGLIARESI, C.; KIRKPATRICK, C. J. Outgrowth endothelial cells isolated and expanded from human peripheral blood progenitor cells as a potential source of autologous cells for endothelialization of silk fibroin biomaterials. Biomaterials, v.27, n.31, p.5399-5408, 2006.

GEORGE, A. VEIS, A. FTIRS in $\mathrm{H}_{2} \mathrm{O}$ demonstrates tha collagen monomers undergo a conformational transition prior to thermal self-assembly in vitro. Biochemistry, v.30, p.2372$2377,1991$.

GIBRAN, N.S. et al. Basic fibroblast growth factor in the early human burn wound. Journal of Surgical Research, v.56, p.226-234, 1994.

GOISSIS, G; PLEPIS, A. M. G.; ROCHA, J. L. Processo de extração de colágeno de tecidos animais com auxílio de solvente orgânico em meio alcalino. Patente Industrial $\mathrm{n}^{\circ}$ 9.405.043$0 / 1994$. 
GOISSIS, G.; BRAILE D. M.; GIGLIOTI, A. F. Desenvolvimento de processo automático para a reticulação progressiva de matrizes de colágeno com glutaraldeído. Polímeros: Ciência e Tecnologia, v.9, p.92-96, 1999.

GOMES, M. et al. Natural polymers in tissue engineering applications. In: Van Blitterswijk, C. (Ed.), Tissue engineering. Academic Press, 2008. p.145-192.

GRIFFITH, L. G. Polymeric biomaterials. Acta Mater., v.48, n. 1, p.263-277, 2000.

GRIFFTH, L.G.; NAUGHTON, G. Tissue engineering-current challenges and expanding opportunities. Science. v. 295, p.1009-1014, 2002.

GUPTA, M.K. et al. Patterned silk films cast from ionic liquid solubilized fibroin as scaffolds for cell growth. Langmuir, v.23, n.3, p.1315-319, 2007.

HARDY, J. G., SCHEIBEL, T. R. Composite materials based on silk proteins. Progress in Polymer Science, v.35, n.9, p.1093-1115, 2010.

HE, L.H., STANDARD, O.C., HUANG, T.Y et al. " Mechanical behavior of porous hydroxyapatite” Acta Biomaterialia, v.04, n.03, pp.577-586, 2008.

HELMUS, M. N.; TWEDEN, K. Materials Selection. In: Wise, D. L. Encyclopedic Handbook of Biomaterials and Bioengineering, part A v.1. Dekker, Marcel Inc, 1995. p. 27-59.

HENCH, L. L. Bioactive materials: the potential for tissue regeneration. J. Biomed Mater Res., v.15, p.511-518, 1998.

HOLLISTER, S. J. Porous scaffold design for tissue engineering. Nat. Mater, v.4, p.518-24, 2005.

HOSSAIN, K.S. et al. Dilutesolution properties of regenerated silk fibroin. Journal of Physical Chemistry B., v.107, p. 8066-8073, 2003.

JANCAR, J. et al. Mechanical response of porous scaffolds for cartilage engineering. Physiol. Res., v.56, p.17-25, 2007.

JIN, H.-J.; KAPLAN, D. L. Mechanism of silk processing in insects and spiders. Nature, v. 424, n. 6952, p. 1057-1061, ago. 2003. ISSN 0028-0836

KAWACHI, E. Y. et al. Biocerâmicas: tendências e perspectivas de uma área interdisciplinar. Quím. Nova, v. 23,p. .518-522, n. 4, 2000.

KHAN, Y.; EL-AMIN, S. F.; LAURENCIN, C. T. In vitro and in vivo evaluation of a novel polymer-ceramic composite scaffold for bone tissue engineering. Eng. Med. Biol. Soc.,v.1, p.529-530, 2006.

KIM, H.S. et al. Preparation of a porous chitosan/fibroin-hydroxyapatite composite matrix for tissue engineering. Macromolecular Research, v.68, n. 4, p.740-745, 2007. 
KITAGAWA, T.; YABUKI, K. Physical properties of silk fibroin/chitosan blend films. Journal of Applied Polymer Science, v.80, n.7, p.928-934, 2001.

KORBLING, M. et al Z .Hepatocytes and epithelial cells of donor origin in recipients of peripheral-blood stem cells. N. Engl. J. Med., v. 346, p.738-746, 2002.

KULKARNI, R. K. et al. Polylactic Acid for Surgical Implants. Arch. Surg. v. 93, n. 5, p.839-843, 1966.

LANGER, R.; VACANTI, J. P. Tissue engineering. Science, v. 260, p. 920, 1993.

LAWRENCE, B.D, et al. Processing methods to control silk fibroin film biomaterial features. Journal of Materials Science, v. 43, n. 21, p. 6967-6985, 2008.

LE BLANC, et al. Development of human fetal mesenchymal stem cell mediated tissue engineering bone grafts. Biomaterials, v.3, p.345-50, 2003.

LI, M. et al. Structure and properties of silk fibroin-poly(vinyl alcohol) gel. International Journal of Biological Macromolecules, v.30, p. 89-94, 2002.

LI, M.; OGISO, M.; MINOURA, M. Enzymatic degradation behavior of porous silk fibroin sheets. Biomaterials, v. 24, p.357-365, 2003.

LI, Y. et al. Anisotropic growth of hydroxiapatite on the silk fibroin films. Applied Surface Science, v.255, p.1681-1685, 2008.

LIANG, D.; HSIAO, B.S.; CHU, B. Functional electrospun nanofibrous scaffolds for biomedical applications. Advanced Drug Delivery Reviews, v.59, p. 1392-1412, 2007.

LIN, L. et al. Degradation behavior and biocompatibility of nano-hydroxyapatite/silk fibroin composite scaffolds. Acta Chimica Sinica, v.66, p. 1919-1923, 2008.

LIN, H.R. et al. Attachment of stem cells on porous chitosan scaffold crosslinked by $\mathrm{Na}_{2} \mathrm{P}_{3} \mathrm{O}_{10}$. Materials Science and Engineering C, v.27, n.2, pp.280-284, 2007.

LIU, T. V.; BHATIA, S. N. Adv. Drug Deliver. Rev., v.56, p.1635 , 2004.

LLOYD-EVANS, M. Mater. Today, May, p.48,2004.

LV, Q., et al. Preparation of insoluble fibroin films without methanol treatment. Journal of Applied Polymer Science, v. 96, n. 6, p. 2168-2173, 2005.

MA, P. X. Tissue Engineering. In: MARK, H.F. (Ed.) Encyclopedia of Polymer Science and Technology, 3rd Edition. New York: John Wiley \& Sons, 2004.

MA, P. X.; ZHANG, R. Fibrillar Matrices. US Patent 6,146,892, 2000.

MANDAL, B.B., KUNDU, S.C. Cell proliferation and migration in silk fibroin scaffolds. Biomaterials, v.30, n.15, p. 2956-2965, 2009. 
MANGI, G.; et al. In vitro differentiation of chick embryo bone marrow stroma cells into cartilaginous and bonelike tissues. J. Bone Joint. Surg., v.16, p.181-89, 2003.

MAYNE, R.; BURGESON, R. E. Structure and Function of Collagen Types. London: Academic Press, 1987. 317p.

MARKOVA, K. FILIPPIDIS, A. Aplication of TG-DTA to the study of Amynteon lignites, northern Greece. Thermichimica Acta, v. 371, p. 137-141, 2001.

MEINEL, L. et al. The inflammatory responses to silk films in vitro and in vivo. Biomaterials, v.26, p. 147-155, 2005.

MILMAN, B. L. Identification of chemical compounds. Analytica Chimica Acta, v. 24, Issue 6, p. 493-508, 2005.

MIYAGUCHI, Y.; HU, J. Physicochemical properties of silk fibroin after solubilization using calcium chloride with or without ethanol. Food Science and Technology Research, v. 11, n. 1, p. 37-42, 2005.

MORI, H.; TSUKADA, M. New silk protein: modification of silk protein by gene engineering for production of biomaterials. Molecular Biotechnology, v.74, p.95-103, 2000.

MONTANHA V.C., WODEWOTZKY T.I., YOSHIOKA S.A. Processo de preparação de microesferas ou microparticulasde colágeno ou fibroína, e microesferas ou micropartículas de coágeno ou de fibroína obtidas pelos mesmo. $\mathrm{N}^{\circ}$ 18110031785.17 de agosto de 2011.

NOR, J.E. et al. Engineering and characterization of functional human microvessels in immunodeficient mice. Lab. Invest., v.81, n.4, p.453-63, 2007.

OGAWA, C.A. Compositos Hidroxiapatita: Colágeno. Preparação, caracterização e estudos em liberação controlada de ciprofloxacina. Dissertação. Instituto de Química de São CarlosUniversidade de São Paulo, 2002.

ORLIC, Y. et al., Fibrin sealant tissue adhesive - Review and update 2001

PAVIA, D. L.; LAMPMAN, G. M.; KRIZ, G. S. Introduction to spectroscopy: A guide for students of organic chemistry. Philadelphia: Ed. Saunders, 1996.

PITTENGER; et al. Mesenchymal stem cells: paradoxes of passaging. Exp. Hematol., v.32, p.414-25, 1999.

PLEPIS, A.M.D.; GOISSIS, G.; DAS-GUPTA, D.K. Dielectric and pyroeletric characterization of anionic and native collagen. Polymer Engineering and Science, v.36, p.2932-2938, 1996.

PUTNAM, A.J; MOONEY, D.J. Tissue engineering using synthetic extracelluar matrices. Nat Med., v. 2 , n.7, p 824-6, 1996. 
RAVAGLIOLI, A.; KRAJEWSKI, A. Bioceramics - Materials, Properties and Applications. London: Chapman e Hall, 1992. p.422.

REN, Y. J. et al. Preparation and characterization of Antheraea pernyi silk fibroin based nanohydroxyapatite composites. Journal of bioactive and compatible polymers, v.22, p.465-475, 2007.

RESENDE, C.X. Desenvolvimento de compósito dupla camada a base de quitosana para aplicação em reconstrução tecidual. Tese. Universidade Federal do Rio de Janeiro, Rio de Janeiro, 2010.

RODRIGUEZ, A. I. R., BICALHO, S. M. C. M. Revista Científica Eletrônica de Medicina Veterinária-FAMED/FAEF, ano VII, n.13, 2009.

ROSA, A. L.; DE OLIVEIRA, P. T.; BELOTI, M. M. Macroporous scaffold associated with cells to construct a hybrid biomaterial for bone tissue engineering. Expert Rev. Med. Devices. v.5, p.719-28, 2008

RUSA, C. C. et al. Conformational changes induced in Bombyx mori silk fibroin by cyclodextrin inclusion complexation. Macromolecules, v.38, p.5640-5646, 2005.

SANCHEZ, C. et al. Biological structures - The epitome of 'bottom-up' fabrication. Nat. Mater., v.4, p.277, 2005.

SANTIN, M. et al. In vitro evaluation of the inflammatory potential of the silk fibroin. Journal of Biomedical Materials Research, v.46, p.382-389, 1999.

START, S., SCHNEIDER, Y.J., AGATHOS, S.N. Ear mesenchymal stem cells: An efficient adult multipotent cell population fit for rapid and scalable expansion. Journal of Biotechnology.v.139,p 291-299, 2009.

SATOH, F.; et al. Bacterial cellulose as a potential scaffold for tissue engineering of cartilage. Biomaterials., v.26, p.419-31,2004.

SERVOLI, E. et al. Surface properties of silk fibroin films and their interaction with fibroblasts. Macromolecular Bioscience, v.5, n.12, p.1175-1183, 2005.

SCHAFFNER, P.; DARD, M. M. Structure and functions of RGD peptides involved in bone biology. Celular and Molecular Life Sciences, v.60, p.119-132, 2003.

SILVA, M. H. P. Apostila de Biomateriais, CERAMED 2007.

SILVA, W. J. et al. In vivo biocompatibility of bacterial cellulose. J. Biomed. Mater. Res. A., v.76, p.431-8, 2005.

SILVERSTEIN, R. M.; WEBSTER, F. X. Identificação Espectrométrica de Compostos Orgânicos. 6 ${ }^{\text {a }}$ ed. Rio de Janeiro: Editora LTC, 2000.

SIONKOWSKA, A. Modification of collagen films by ultraviolet irradiation. Polymer Degradation and Stability, v. 68, p.147-151, 2000. 
SKOOG, D. A.; HOLLER, F. J.; NIEMAN, T. A. Princípios de Análise Instrumental, 5 ed. Porto Alegre: Editora Bookman-SBQ, 2002.

SHU-TUNG, L. Biologic Biomaterials: Tissue-Derived Biomaterials (Collagen). In: BRONZINO, J. D. (Ed). The Biomedical Engineering Handbook: Second Edition. Boca Raton: CRC Press LLC, 2000

TAMADA, Y. New process to form a silk fibroin porous 3-D structure. Biomacromolecules, v.6, p.3100-3106, 2005.

TANAKA, K. et al. Determination of the site of disulfide linkage between heavy and light chains of silk fibroin produced by Bombyx mori. Biochimica et Biophysica Acta, v.1432, p. 92-103, 1999.

TRABBIC, K. A.; YAGER, P. Comparative structural characterization of naturally and synthetically-spun fibers of Bombyx mori fibroin. Macromolecules, v.31, p.462-471, 1998.

TSUKADA, M. et al. Structure and Dyeability of Bombyx-Mori Silk Fibers with Different Filament Sizes. Applied Polymer Science, v. 60, p.1619-1627, 1996.

TZAPHLIDOU, M. et al. The collagen fibril - a model system for studying the staining and fixation of a protein. Electron Microscopic Reviews, v.3, n.1, p. 143-182, 1990.

UM, I.C., et al. Wet spinning of silk polymer II. Effect of drawing on the structural characteristics and properties of filament. International Journal of Biological Macromolecules, v. 34, n. 1-2, p. 107-119, 2004.

UM, I.C. et al. Structural characteristics and properties of the regenerated silk fibroin prepared from formic acid. International Journal of Biological Macromolecules, v.29, p.91-97, 2001.

UTRACKI, L. A. Polymer Alloys and Blends: Thermodynamics and Rheology. New York: Hanser Publishers, 1990. 356 p.

VALIMAA, T. \& LAAKSOVIRTA, S. - Bioresorbable polymers in tissue engineering Biomaterials, v.25, p.1225, 2004.

VEPARI, C., KAPLAN, D.L. Silk as a biomaterial. Progress in Polymer Science, v.32, n.8, pp.991-1007, 2007.

VIDAL, B. C. Crimp as Part of a Helical Structure. Life Science Biochemistry, v.318, p. 173-178, 1995.

VOSKERICIAN, G.; et al. Macroporous condensed poly (tetrafluoroethylene). In vivo inflammatory response and healing characteristics. J. Biomed. Mater. Res. v.76 A, p.234, 2006

XU H. H.; WEIR M. D.; SIMON C. G. Injectable and strong nano-apatite scaffolds for cell/growth factor delivery and bone regeneration. Dent Mater., v.24, n.9, p.1212-22, 2008. 
ZHANG W. et al. Hard tissue formation in a porous ha/tcp ceramic scaffold loaded with stromal cells derived from dental pulp and bone marrow. Tissue Eng. Part. A., v.14, n.2, p.285-94, 2008.

ZUO, B.; LIU, L.; WU, Z. Effect on properties of regenerated silk fibroin fiber coagulated with aqueous methanol/ethanol. Journal of Applied Polymer Science, v. 106, n. 1, p. 53-59, 2007.

WANG, J. et al. Biodegradáveis andaimes microfluídicos para engenharia de tecidos de amino base de álcool poli (amida éster) elastômeros. Organogênese 2010.

WANG, S. et. al. Silk-The Prospective and Compatible Bio-Material for Advanced Functional Applications. Biomaterials, p. 1243- 1247, 2005.

WENK, E., MERKLE, H.P., MEINEL, L. Silk fibroin as a vehicle for drug delivery applications. Jornal of Controlled Release, v.150, n.2, p.128-141, 2011. 